

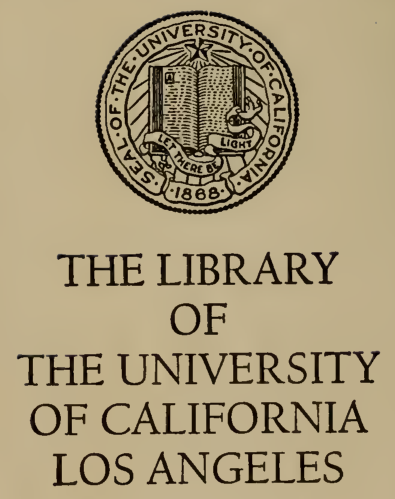







\section{Agrieultural Organisation}

Its Ruse, Principles, and Practice Abruad and at Home

BDWIN A. PRATT

CHEAP EDTTION

व०68 81

ONE SHILLING NET 


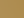




\section{AGRICULT UR A L \\ ORGANISATION}

ITS RISE, PRINCIPLES AND PRACTICE

ABROAD AND AT HOME

BY

EDWIN A. PRATT

AUTHOR OF

"THE ORGANISATION OF AGRICULTURE," "THE TRANSITION IN AGRICULTURE,

"A HISTORY OF INLAND TRANSPORT AND COMMUNICATION," ETC.

\section{CHEAP EDITION}

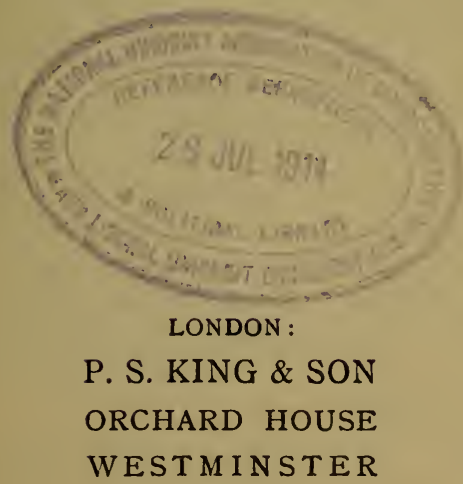

I9I4 
FIRST EDITION (3s, 6d.)

Cheap Edition (18.)

Published November, 1912

" June, 1914

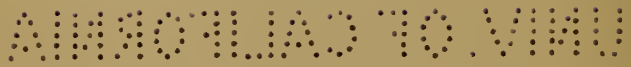




\section{3 \\ $988 a$ \\ 1914}

\section{PREFATORY NOTE}

AGRICULTURAL Organisation ranks to-day as one of those . world movements to which countries great and small throughout the civilised globe are devoting attention, while the fact that in I9I3 the members of an American Agricultural Commission made the tour of Europe in quest of information on the subject is but one of many recent developments which might be adduced as evidence of the earnest study now being devoted to a subject that affects so closely the social and economic well-being of the nations. Though, also, based primarily on the principle of combination for the three-fold purposes of production, transport and sale, Agricultural Organisation is concerned directly or indirectly with a wide range of other questions and problems of the day, including those relating to the rural exodus, the settlement of more people on the land, the revival of country life, wages and housing in country districts, the higher cost of living due to (among other causes) the world's increasing consumption of food supplies, and the desirability of reducing so far as is practicable our dependence on foreign imports.

The time has thus seemed to be opportune for the re-issue of the present work in a cheaper and somewhat more compact form, the detailed account of "Work Done or Projected " by the Agricultural Organisation Society of England, which occupied considerable space in the first edition," being here omitted; though all the material facts in relation to the "Rise, Principles, and Practice" of agricultural organisation, both abroad and at home, as given in the original edition, have been retained.

EdWin A. Pratt.

June, I9I4.

* Copies of the Ist Edition can still be procured from the publishers at 3s. $6 d$. net. 


\section{CONTENTS}

CHAPTER

I. Rise and Development . . • • I

II. EXAMPLES FROM OTHER LANDS • • • 22

III. The Position at Home - • $\quad$ - 53

IV. The Movement in Ireland • $\quad$ - 74

V. Evolution of the Agricultural OrganisaTION SOCIETY-

A. Earlier Efforts . $\quad$ • . $\quad$ • 88

B. Progress and Development . . . I03

C. State Aid and Public Approval . . II4

D. Reconstitution . . . . . 125

E. Devolution . . . . . . I3I

VI. TRANSPORT QUESTIONS . . . . . I40

VII. SUMmaRy AND CONClusions . • . I6r 


\section{AGRICULTURAL ORGANISATION}

\section{CHAPTER I.}

\section{RISE AND DEVELOPMENT.}

THE extent to which agricultural organisation, in some or other of its manifold phases, has been adopted in recent years in almost every civilised country on the face of the globe constitutes one of the most remarkable of economical developments, and one that has, besides, had considerable bearing on general social conditions.

Of the greatest and most direct interest to those actually engaged in agriculture, the subject is also one that must appeal strongly to all who are in any way interested in the progress of nations; and the story of how so remarkable a movement was brought about, and of the results to which it has already led, should appeal no less to the average citizen than to the working farmer. It should, further, lead to the conviction that, when so many countries throughout the world which look to the United Kingdom as the best market for their surplus produce are both increasing the volume thereof and strengthening their economic position, it is a matter of special importance that British producers should enquire what are the special advantages which (apart from climatic or other conditions not capable of reproduction here) their foreign competitors have secured for themselves from effective organisation, and to what extent the example set by the foreigner should be followed by the British farmer, alike in the defence and for the promotion of his own interests.

Conditions naturally vary in all the countries concerned, A.O. 
and no system of agricultural organisation adopted in any one of them might be suitable for exact reproduction in any other country; but there are main principles which are, nevertheless, capable of general application. These general principles are invariably determined by what have been called " the urgent exigencies of economic life" ; and in few, if any, countries are such exigencies more urgent, from an agricultural point of view, than in a land like our own where there is so great an industrial population to be fed, and where, at the same time, so active a competition has had to be faced by home agriculture in providing the needed supplies.

To the economist the subject here under consideration must be a matter of particular interest, since agricultural organisation is effecting material changes in the circumstances of many different countries; the politician will see the growth in those countries of an Agricultural Party which, in carrying on a new " Peasants' War "-not against rulers, but against economic conditions--represents a steadily-increasing force to be reckoned with by the makers of laws; and the psychologist will observe how a section of the community hitherto distinguished in almost every land for inveterate suspicion and distrust of neighbours has itself mainly taken the initiative in a movement essentially democratic in its origin-whatever the degree to which State-aid has subsequently been rendered-and directly designed to lead the agricultural classes to abandon their said suspicion and distrust and operate on the lines of common action for the securing of common advantages, the social and individual results brought about having thus been no less remarkable even than the economic.

\section{Agricultural Combination in the Past.}

In the principle of combination for the purpose of fostering the interests either of agriculture as a science or of agriculturists as a class there is, of course, nothing new. Just as the cultivation of the soil is the oldest of callings, so do we find in the agricultural industry some of 
the earliest developments of that Spirit of Association which, in this age of societies, leagues, unions and federations of every class and description, may be considered one of the characteristics of present-day Society.

In France, for instance, agricultural combinations began in the time of the Romans and were continued through the mediæval ages, leading up to the present widespread form of legal association regulated by special statute. These early combinations were brought about mainly by landowners who joined together, at different periods, for the collective cultivation of their properties, for mutual defence against drought or inundation, for the drainage of bogs or swamps, for the organisation of mutual insurance, or for the furthering of their general interests by the holding of shows, the study of agricultural questions, and so on.

In Portugal the institution known as the Misericordia, which, among other beneficent purposes-and on the basis of fixed subscriptions-granted loans to farmers at a certain interest, dates back to 1498 ; but it was the Celleiros, of which the first was founded in $1_{576}$, thatoperated as benevolent institutions-more especially sought to afford help to small cultivators by advancing them seed at a fixed rate of interest, to be repaid in kind by the end of the year.

In Austria associations of agriculturists, consisting mostly of large landowners, began to be formed in the second half of the eighteenth century with the object of contributing to the progress of agriculture by means of research, instruction, conferences, shows and the influencing of legislation.

In the United Kingdom the Royal Dublin Society dates from I73I, the Highland and Agricultural Society of Scotland from 1784 , the Smithfield Club from I798, and the Royal Agricultural Society of England from 1838 ; and these organisations have, in turn, been supplemented by many county or local agricultural societies, live-stock societies and other bodies for the promotion or the protection of farmers' interests in general. 
No one would deny that very useful work has been done by these older types of organisation; yet their limitations are no less obvious. The organisations here in question have sought to promote the welfare of agriculture rather than to meet the needs of individual agriculturists. They have told, or shown, the farmer what to produce; but they have mostly left him to his own resources both in raising the ways and means by which he can act on their guidance and in disposing of his supplies to advantage when he has got them ready for the market. They have helped him greatly in the science of agriculture, but very little in the business of agriculture.

Hence there arose the need that the older type of societies, while left to continue their own valuable work, should be supplemented by a newer type which would (I) popularise the agricultural science the older societies were promoting; (2) open out to the producer greater opportunities for raising his supplies to advantage; and (3) organise his business for him on such lines that he would be assured a better return therefrom than if he were left to his own individual resources.

Thus between the old movement and the new movement there should be no fear of friction. To a certain extent the former has prepared the way for the latter; but the one is, even to-day, quite as necessary as the other, and the two should be able to work together in perfect harmony.

To the bringing about of this newer movement, based, not alone on sound economic, but also on co-operative, principles, many different causes have contributed; and for a clear understanding of the whole position it is necessary that these should be taken into consideration.

\section{Agricultural CREdit.}

The beginnings of the agricultural organisation movement of to-day are to be found in the initiation, in Germany, of a system of agricultural credit in the special interest of small producers. 
In some quarters there is a tendency to discourage the idea of cultivators " running into debt," as it is said, for the carrying on of their enterprises; yet farming is to be regarded, not only as a business, but as a business in which a facility to obtain capital readily, on reasonable terms, may be still more necessary than it is in the majority of other businesses.

Whereas the ordinary trader, operating with borrowed money, may expect to start almost at once with a turnover, the cultivator must prepare his fields, sow his seed, await the processes of Nature in the growing and the ripening of his crops, gather in the eventual harvest, and then dispose of it on the market, before he can hope to secure any return on his investment and his toil : and he must have the means to defray cost of seed, labour and machinery, to cover rent, rates and taxes, and to support himself and his family during the time when the money is all going out and none is coming in.

On the other hand, the small cultivator has always been in a position of special disadvantage, as compared with large farmers or traders in general, in obtaining the often indispensable loans, owing to his inability to offer what the ordinary banker would regard as adequate security; and, in the result, he has been in all ages and in all lands the prey of the money-lender, who has too often practised upon him the most shameless usury, even if he should not have reduced him to a position not far removed from that of actual servitude. The money-lender may have pleaded that he ran greater risk in lending to the small farmer than in lending to the trader since the one had little that could be seized in default of payment while the other had, at least, his stock of goods; but none the less may the cultivator have been virtually the slave of the usurer. In a report on Roumania, published in Bulletin No. 2 of the Bureau of Economic and Social Intelligence, International Institute of Agriculture, one may read on this subject :-

It may be objected that credit is still hard to get ; that ro per cent. interest is too high; that here and there are small mis- 
appropriations; that small abuses occur still; and that the exploitation of the peasant has not yet disappeared everywhere. But, in spite of all this, we have left far behind the days when a peasant could not borrow money unless he paid two or three francs a month for every twenty francs; when usurers swarmed in and out of villages, and speculated mercilessly on dire need and misery: when neither the law nor the administration could protect the worker from this slavery, or mitigate his frightful poverty, or prevent the abuses of speculation on labour which led to the revolution of 1907 .

India is an exceptional country in matters of finance, since a rate of interest amounting to $12 \frac{1}{2}$ per cent. is there regarded as reasonable even by the credit societies, and anything below 9 per cent. is looked upon as a mistake; but even these rates are modest compared with the $24,36,60$ and even 75 per cent. charged in different provinces by village money-lenders.

It was the inauguration of the Raiffeisen system of rural credit in Germany, where, in the middle of the nineteenth century, the money-lender had become all-powerful in the poorer agricultural districts, that showed the way out of the difficulty by which the small cultivator was faced. His lack of visible security was met by the formation of village or local societies whose members became jointly and severally responsible for the repayment of loans which they themselves granted to men whom, from personal knowledge, they regarded as worthy of confidence, while the loans were to be applied to specified purposes of an exclusively reproductive character.

Starting in this very small way, the Raiffeisen system underwent various developments, eventually gave rise to the creation of a net-work of societies, federations and state or provincial agricultural credit banks, spread into many different lands, and forms to-day the basis on which has been built up much of the systematic organisation of agriculture that has become so active a force throughout the world in general.

Scientific Production.

The need alike for agricultural credit and for agricultural organisation became greater by reason of the changes in 
the methods of production due to the teachings of Liebig and others, following on the discoveries made by them in what they showed to be the science, and not simply the practice, of agriculture.

Owing to the more intensive forms of cultivation which thus came into vogue, there was brought about, on the one hand, a greatly increased demand for artificial manures and other requisites, and, on the other hand, the creation of an army of manufacturers, agents and middlemen who, in seeking to supply this demand, regarded agriculture from a purely business point of view, and were apt to look upon the farmer as someone whom, in the new conditions of production by which he was faced, they could exploit to their own advantage.

The advance in agricultural science thus meant for the farmer that not only must he have the capital with which to purchase the requisites in question-so that here there came still further reasons for agricultural credit-but there was the further material danger that if the manufacturers of these requisites were none too honest and reasonable, and if the middlemen dealers passing them on to him were alike ignorant and unscrupulous, then, left to his own resources, he might have to pay an excessive price for raw materials of inferior quality, and also eventually gain an inadequate return from his crops.

These results were, in fact, experienced in Germany almost as soon as the system of scientific production came into vogue; and the earliest measures adopted to check them took the form of " control," or " test " stations set up by certain non-trading agricultural associations for the purpose of analysing or otherwise testing the commodities in question. This arrangement answered when the buyer himself sent in the wares he had purchased, but was regarded with suspicion if the middleman claimed to have had the tests made before the sale.

When, therefore, the Raiffeisen banks began to spread in Germany, the further expedient was resorted to by them of arranging for the purchase of agricultural necessaries by or 
on behalf of the associated farmers through the instrumentality of the rural or agricultural bank, which was thus not only to provide the cultivator with credit, and so keep him out of the hands of the usurer, but also to enable him to lay out his money to the best advantage.

These arrangements, applied in the first instance mainly to fertilisers, were afterward; extended to the improved machinery and the concentrated feeding stuffs which agricultural science had likewise introduced in the interest of better production.

Co-operative Purchase.

Meanwhile the great increase in the demand for all these things had led the industrial and commercial interests concerned in their supply to form "trusts," " rings," or "syndicates," with a view both to controlling the output and to keeping up the prices. So there came still further need for the farmers to combine in self-defence.

Special societies for joint purchase now began to be formed, as distinct from what the rural banks had been doing, and in course of time the new societies joined together in federations which were in a better position to deal direct with manufacturers and to obtain lower terms for their affiliated societies by purchasing large quantities, and by saving intermediate profits, while they could also arrange for trustworthy analyses, and thus obtain a guarantee of quality.

All these things helped even the small producer both to face the changes that science had introduced into production and to put his business of agriculture on a better business footing.

\section{FOREIGN WHEAT.}

The forcing on the producer of these various measures became still more pronounced under the conditions leading to the agricultural crisis which began to affect Europe in general when the newer countries were able to send, at low 
charges for ocean transport, enormous supplies of wheat to be sold here at prices with which the European grower could not compete.

\section{STEAM-TELEGRAPHY-REFRIGERATION.}

By the application of steam to the propulsion of oceangoing vessels a complete transformation was brought about in our trading relations with distant countries, as compared with the days when dependence had to be placed on sailing ships.

By the invention of the telegraph and the laying of ocean cables there came a no less revolutionary change in the facilities of communication, with a consequent further great expansion in our foreign and commercial trade, and especially so when other lands, developing their own agricultural resources, began to have increasingly large surplus stocks for which they sought an outlet here.

Still another change in the situation was effected through the use of refrigeration processes in the transport of perishable products from over-sea countries.

As the outcome of this further application of science to agricultural conditions, these perishable products, sent from Australia, New Zealand, and Argentina, can be put on our markets in perfectly sound condition, notwithstanding the great length of the journey; while under existing contracts frozen meat is brought from Australia to London for ninesixteenths of a penny per pound, fresh fruit for seven-eighths of a penny per pound, and butter for one half-penny per pound.

Thus refrigeration has annihilated distance, while the cost of ocean transport has, from a marketing point of view, become a negligible quantity. Producers in those far-off lands are, for all practical purposes, and with various advantages of their own, as much competitors of British agriculturists as if their countries immediately adjoined our own shores. 


\section{The Transition in Agriculture.}

All these conditions, and others besides, led to an increased need here, not only for greater efficiency, but also for a greater variety, in agricultural production. It became necessary that European growers who could no longer compete, more especially, with foreign wheat should turn their attention to other products instead, and such necessity led to a period of transition in which alternatives to wheatgrowing were widely adopted, among those alternatives being stock-breeding, the raising of market-garden produce, fruit culture, and the sale of milk, butter, cheese, eggs and poultry.

\section{URBAN LIFE.}

Such transition was, in turn, greatly fostered by the altered conditions of urban life.

The transformation in the industrial position owing to the invention of new processes of manufacture, the setting up of the factory system, and the migration of population from the rural districts to the towns had both discouraged the practice of the older forms of agriculture at home and opened out still greater possibilities to the wheat-growers abroad; but the same transformation had also led to the grouping together of collections of humanity which could, indeed, no longer grow their own food supplies on their own holdings, yet stood in need of commodities besides wheat or bread, and especially of vegetables, fruit, milk, butter, cheese, and bacon.

The furnishing of these other commodities offered scope for the enterprise and energy of cultivators unable to compete with the foreign wheat-grower, while the transition in agriculture thus brought about further meant an increase of opportunity for the working farmer and the small holder-especially under conditions of intensive cultivation-notwithstanding the increasing discouragement for the gentleman farmer whose broad acres had been devoted in the past to the production of corn crops.

These newer possibilities of the situation became greater 
still in proportion as the industrial and middle classes regarded more and more in the light of necessaries what their forefathers would have considered luxuries, even if they had, in their day, been able to obtain them at all; and, in the result, although foreign competition caused a shrinkage in the area devoted to wheat, the needs of urban populations led to an increased demand for other food supplies of a type that once more widened out the scope for agricultural organisation.

\section{EXAMPLE OF DenMaRK.}

While these various conditions had been affecting Europe in general, Denmark was, more especially, stirred into action by the urgent need, following on the results of her conflict with Prussia, to improve her economic condition; and this she sought to do by organising her agricultural industries on such a basis that she could supply other countries, and more particularly Great Britain, with the butter, bacon and eggs that are now no less needed than wheat, flour and bread. Opportunity for agricultural expansion was thus opened out to Danish producers who, in the circumstances, could afford to disregard the competition of wheat from the American continent or elsewhere.

\section{Organisation For Production.}

Denmark, too, carried the general movement still further. Her peasant proprietors followed up organisation alike for credit and for collective purchase by organisation for production. Regarding agriculture as a business, they applied to it the same principle of a "factory" that Manchester cotton-spinners had already applied to their own industry, the main difference in such application being that the Danes worked together mainly on co-operative lines.

Once more we may find precedents for the course thus adopted. So far back as the fourteenth and fifteenth 
centuries it was the practice of peasants in the Alpine valleys of Italy to bring together their supplies of milk and treat them in common, for the production of cheese, in the house of each associate in succession. Here one does, indeed, get the principle of combination; but, in actual practice, the setting up of a factory, for dealing with the milk or cream produced within a certain radius, was a much more advanced form of combination.

It was in the United States that the modern type of dairy factory originated. The first was organised in the State of New York in I860, and by 1866 there were nearly 500 in operation. At the outset the factories made cheese only, but creameries, or butter factories, followed soon after, though these did not come into general vogue until I880.

Two years later the Danish peasant proprietors set up their first butter factory on strictly co-operative lines; and since that time the expansion of this principle, both in Denmark and in other countries, has been great indeed, thanks to the progress alike of science and of the spirit of association.

Science assisted, if it did not really establish, the movement through the invention, by Lehfeld, in 1876 , of the centrifugal cream separator, which allowed of a greater yield of cream and, consequently also, of butter, from the milk. Every farmer could not afford to have a separator of his own, and it was obviously better that, instead of each remaining independent of his neighbour, groups of them should co-operate to obtain the necessary appliances and appoint a skilled staff to make their butter for them in factories established for the purpose and under such conditions that the cost of production would be reduced to a minimum, while the supply of large quantities of butter of uniform quality would be assured.

In 1887 the Danes further set up their first co-operative bacon factory.

Combination for production to-day forms one of the most important phases of the agricultural organisation 
movement. It has undergone varied and widespread development, and is to be found in one form or another in almost every country where organisation has taken root. Everywhere it is regarded as an important means of cheapening cost of production, and hence, also, of giving the associated farmers an initial advantage on the world's markets.

\section{LIve STOck.}

The application of the factory system here in question, and the resort thereto on so extensive a scale by dairy farmers, led to greatly increased importance being paid to the subject of cattle-breeding since it was, of course, most desirable in their own and the general interest that the associated farmers should show a preference for such cows as were likely to give the largest supplies of the richest quality of milk.

So co-operation went a step further in the formation of new types of agricultural associations which (I) sought to promote a scientific system of cattle-breeding, based on biological laws and the results of heredity; (2) established breeding syndicates; and ( 3 ) organised a "control" system to keep account of the milk-giving qualities of each cow and enable the farmer to know, from definite data, which animals gave the best results.

In other words, science was once more adopted in place of rule-of-thumb, while in thus taking advantage of science, both in principle and in practice, the humblest peasant was, thanks to co-operation, placed on a footing equal to that of the most influential of land-owners or the largest of farmers.

So much was this the case in Denmark that, although peasants initiated the agricultural co-operative societies, landowners and large farmers found it to their own advantage, in various ways, to join them.

In addition to the co-operative societies in respect to cattle, others were established to improve the breed of pigs, 
horses, goats, and poultry. Bee-keepers' societies were likewise formed.

\section{CO-Operation for Sale.}

As a natural sequel to combination for production came co-operation for sale. Men who had joined together in order to produce to the best advantage might, also, well act together to sell to the best advantage.

There was, in the first place, the fact that good producers are not necessarily good business men-that they may be better employed in doing work on their farm or holding to which they are thoroughly suited than in looking after marketing details which, especially when a number of producers are already acting together, may much more suitably be left to some specially competent and trustworthy person selected for that purpose.

In the second place combination for sale meant, in the case of foreign producers, at least, that they could make up complete train loads of commodities from a particular district, and obtain the lowest rates for transport because the railway people had less trouble in handling large grouped consignments sent under what were, for them, the most favourable conditions in regard to loading, etc., than they would have had in dealing with a large number of growers each consigning his own particular lot independently of everyone else. Suffice it, in this connection, to speak of the butter and bacon trains in Denmark, the egg trains from Italy, and the fruit and vegetable trains from the South of France, all directed more or less to the English markets.

In the third place combination for sale offered to the wholesale and retail dealers a greater assurance of regular supplies of uniform quality; and in some instances these conditions gave to foreign produce a distinct advantage on our markets over English produce, of varied qualities, and consigned in irregular quantities by wholly independent growers or producers.

In some countries-and especially in Holland-combination for sale led to the setting up of co-operative auction 
marts, where produce or live stock was disposed of under conditions which gave a better prospect of fair prices than when the individual farmer had been left to make the best terms he could with an individual dealer.

Whether with or without these co-operative auction marts, it was found that combination for sale gave better returns to associated farmers who had already, as we have seen, had the advantages resulting from combination for credit and production.

\section{SUPPLEMENTARY Combinations.}

Once successfully established on the broad lines already mentioned, the spirit of co-operation in agriculture spread out in many other directions besides.

Co-operative insurance of livestock, for instance, was very widely adopted. Agricultural accidents were also insured against co-operatively. In some countries insurance against storms or hail was resorted to, and in most of those where agricultural organisation has been established at all, the societies obtain for their grouped members better terms. for fire insurance than could be got through an agent.

In Roumania there are agricultural credit banks which finance rural associations constituted for the special purpose of enabling peasants to lease land direct from the owners of large estates instead of through the middlemen who had previously exploited them.

Co-operative societies of viticulturists, also, are common to most wine-producing countries on the Continent.

\section{Mutual Help.}

Nor have the social advantages been less marked than the economic.

A new spirit is taking possession of the agricultural mind wherever the organisation movement has been established. A new rural democracy, inspired by fresh hopes and aspirations, and with vistas of new possibilities opened 
out, is coming into existence. Old traditions and ancient prejudices which had led each farmer or peasant to act for himself, to keep to himself, and to regard his neighbour with distrust are disappearing in favour of united action for common benefits.

Self-dependence may promote a feeling of independence ; but in the agricultural industry it has its disadvantages. Self-help is excellent so far as it leads a man to make the most of his opportunities; it is less commendable when it leads him to think of self only. From the latter point of view mutual-help is preferable; and it is this broader and still more praiseworthy principle that is at the root of agricultural organisation.

\section{INFLUENCE ON THE INDIVIDUAL.}

Co-operative credit, which is more especially based on the mutual-help principle, has conferred on the individual, not alone material advantages which he could not have secured for himself, but moral advantages that may be of still greater value to him as a man and a citizen.

The security on which a Raiffeisen rural credit society advances loans is the good character of the would-be borrower - his reputation for industry, honesty, sobriety, and trustworthiness in general. Without these qualities he stands no chance of getting a loan, since his associated neighbours controlling the society are not likely, under their obligation of unlimited liability, to run any risk in lending to persons in whom they have no confidence.

So to those who may be endangering their good character a direct incentive is offered to stop in time and mend their ways ; and the moral effect of such incentive on the individual, as the outcome of the organisation movement, is known to be great indeed.

\section{Other Advantages.}

Under the influence, again, of the new movement, men of diverse political and religious views, or of different social 
standing, work together in the furtherance of agricultural co-operation as though they had but one common object in view.

The popularisation of agricultural science by means of pamphlets, bulletins, periodicals, lectures, courses of instruction, schools of farming, shows, experimental fields, and an active propaganda generally are not only bringing about a more or less complete transformation in agricultural production, and advancing the prosperity of those concerned, but are improving the type of the agricultural workers subjected to these beneficial conditions.

New or revived village industries, supplementing agricultural industries proper, give more openings to rural populations and offer them greater inducements to remain in the country, while the business meetings and the social gatherings of the societies, together with the reading rooms, libraries and village halls set up, invest country life with greater attractions which, again, should help to check the migration to the towns, and must in themselves be regarded as preferable to the introduction into country life of urban amusements likely only to increase the desire for urban life.

Thanks, in short, to agricultural organisation, progress to-day is spreading in the backward rural districts in most countries of the world; and this progress means, not only an increase in material prosperity, but social, moral and intellectual development as well.

\section{WOMEN AND RURAL LIFE.}

In the work of social advance and the betterment of rural life women are taking, or are being invited to take, an important part.

Women's Institutes, supplementing the earlier Farmers' Institutes, have undergone great development in the United States and Canada, where they have become an active force in all matters appertaining to household and domestic science, to woman's work on the farm, and to the social conditions of the community in which they operate.

A.o. 
Addressing a general meeting of delegates of the Canadian Women's Institutes, Mr. James, Deputy-Minister of Agriculture for Canada, said :-

It is only a few years since we made the sensational discovery that a farmer had a wife and family. For the first time, I believe, since the beginning of civilisation, we have begun to occupy ourselves with a definite plan for farm women, from the point of view of science and education. I know of no movement that promises so well for the future and for the general well-being of the land as this. It is neither in the stables nor in the fields that we find the real centre of farm work; it is within the four walls of the home.

Institutions of a kindred type have, as will be shown later, since been organised in Belgium, where they have attained to a considerable degree of success.

In France, itinerant schools have been set up with the object of affording instruction in various agricultural and domestic subjects to young women in the rural districts, with a view (I) to giving to those instructed a greater inducement to remain in the country; and (2) to rendering them better qualified to take their part efficiently both in agricultural and in domestic life. The instruction given, either under the direction of departmental professors of agriculture or by skilled lady teachers, includes such subjects as dairy work, gardening, and care of animals, together with a wide range of household duties. Encouraged and subsidised by the French Ministry of Agriculture, the schools are also fostered by the agricultural co-operative societies, some of which have organised ladies' committees to help in the carrying on of the work.

\section{INFLUENCE OF CLERGy.}

Agricultural organisation has here been spoken of as being essentially of democratic origin, both the original founders and the prime movers in subsequent developments being mainly found among the class directly benefited.

In this respect the movement bears a strong resemblance to those great thrift, friendly and distributive co-operative societies which were no less created by the people for the people. 
All the same, one cannot deny that in some countries the great advance of agricultural organisation has been materially due to the influence of the clergy, and in many countries to the sympathetic support, if not the direct action, of the States concerned.

The Roman Catholic clergy in Belgium, for instance, went into the matter of agricultural organisation with a thoroughness that in itself deserved success. The knowledge they acquired of the science of agriculture would have done credit to agricultural-college professors. They learned all about the use of fertilisers at a time when the peasantry regarded artificial manures with the greatest suspicion; they enforced their arguments by cultivating experimental plots of their own; they gave sacks of fertilisers to doubting farmers in order that the latter, in turn, should make experiments on their own account ; they acquired a knowledge of agricultural machinery, and in some instances, at least, were themselves able to put such machinery right for farmers when it broke down ; they spread an active propaganda in support of credit banks, societies for purchase, production and sale, federations, insurance societies, etc. ; and, eventually, with the support alike of the landed gentry and of the Belgian Government, they succeeded so well that to-day there is not a single district of Belgium without its federation of agricultural societies operating under clerical guidance.

In the Catholic districts of Holland the movement has likewise received much active encouragement from the clergy ; in Italy the establishment of a large proportion of the credit banks there has been due to the Catholic clergy; in Austria the priests and the elementary school teachers give instruction or advice to the peasants in agricultural science and on the advantages of co-operation; and in Hungary like action has been taken by the clergy, who find that one incidental result of their activities has been an increase of sobriety, since the Hungarian peasant now spends at the headquarters of his society the time he once spent in the public-house.

As against these examples of clerical influence might, of 
course, be put those of countries like France and Denmark, where the prevailing forces in the spread of agricultural organisation have been essentially economic; but one sees nevertheless, how wide is the range of interests the movement embraces.

\section{State Action.}

While the attitude of Governments all the world over towards agricultural organisation has been essentially sympathetic-and naturally so, in view of the benefits it was certain to confer on the countries concerned-there has been much diversity in the particular courses of action taken.

In countries under Governments of a pronounced bureaucratic type, such as Austria and Hungary, the tendency has been in the direction of the State assuming control of practically the whole movement, not only ensuring the provision of ways and means but undertaking general direction and even small working details.

This policy may be a natural one in countries where the people have been taught to look for almost everything to their Government ; but State-aid carried to these extremes constitutes a "spoon-feeding" which one must regard as an undesirable substitute for either self-help or mutualhelp.

Without going to the same lengths, and while still allowing full scope for independent effort and democratic action, the State in many other countries has rendered invaluable aid to the movement by means of laws giving the societies a legal status; by affording them increased facilities in the scope of their operation; by establishing State, provincial or other central banks to aid in the financing of village credit banks; by affording practical encouragement to scientific research ; by organising systematic instruction in agricultural science; by making loans or grants to supplement associated effort; or by helping both to popularise the movement generally and to establish it on a still sounder 
footing as one of the most important forces of the day from the point of view of national progress.

In the matter more especially of co-operative credit, the ideal conditions are that the State should avoid having direct dealings either with individual cultivators or with local societies, and should establish relations exclusively with central banks undertaking the work of financing lesser federations of bank which, in turn, pass on the State assistance to the local credit banks providing for the wants of their individual members. This system has been adopted in Germany as the outcome of over half a century's experience. It represents a happy combination of State-aid and cooperative effort which, while ensuring an application of the former under the best conditions, still leaves full scope for the activity of the latter, with less risk of the demoralisation that must needs result when the State itself undertakes duties or details which had much better be left to others. 


\section{CHAPTER II.}

\section{EXAMPLES FROM OTHER LANDS.}

To give a full account of the progress made by the movement throughout the world would far exceed the limits of available space; and this fact will be the more evident if it is mentioned that no fewer than fifty States have now given in their adhesion to the International Institute of Agriculture established at Rome in 1905, and that the historical and statistical data published by the Institute's Bureau of Economic and Social Intelligence-data, that is, relating mostly to developments of agricultural organisation in one form or another in these different countries-already fill no fewer than eighteen Bulletins, each consisting of about 250 pages.

All that can here be attempted is to offer, mainly from these Bulletins, a few details concerning certain typical countries with a view less of satisfying the statistician than of convincing the reader that, where so much activity is being shown in lands which are often competitors of our own, it is not for England to lag behind in the march of economic development.

\section{Germany.}

The great expansion of the agricultural organisation movement in Germany is well shown by the following table, which gives the total number of agricultural co-operative societies existing in the German Empire in the years stated :-

\begin{tabular}{|c|c|c|c|c|c|}
\hline \multirow{2}{*}{ YEAR } & \multirow{2}{*}{$\begin{array}{l}\text { LOAN } \\
\text { AND } \\
\text { SAVINGS } \\
\text { BANKS. }\end{array}$} & \multicolumn{4}{|c|}{ Co-operative Societies. } \\
\hline & & $\begin{array}{c}\text { For collective } \\
\text { purchase. }\end{array}$ & Dairy. & Others. & Total. \\
\hline I 890 & 1,729 & 537 & 639 & ror & 3,806 \\
\hline I 900 & 9,793 & I, I I 5 & 1,917 & $8 I I$ & $x_{3,636}$ \\
\hline 1910 & 15,526 & 2,265 & 3,364 & 2,836 & $24,08 \mathrm{I}$ \\
\hline
\end{tabular}


The 15,000 banks are associated with and partly financed by 36 central banks, the total turnover of which in I909 was $£ 245,689,000$. The figure further includes 4,399 co-operative credit societies, affiliated to the Raiffeisen Organisation. In the case of 4,I54 of these societies supplying data, we get the following details for the year I909:-Total membership, 432,000; total amount of business done, $£ 60,059,000$; savings deposits, $£ 8,855,000$; withdrawals, $£ 6,290,000$; loans granted during year, $£ 4,544,000$; percentage of loans up to $£ 50,77 \cdot 25$.

Organisations for collective purchase of agricultural requisites, following on the need of the German farmer to meet the combinations of manufacturers and dealers by counter-combinations, has gone even further than the figures in the above table would suggest, since two-thirds of the mutual co-operative credit societies and many of the co-operative dairy societies also purchase for their members. Then the necessity further to counteract the influence of powerful trusts and syndicates in Germany seeking to control the market in fertilisers, feeding stuffs, machinery, oil, coal and almost every other agricultural requisite led the local societies to join together into federations. At first the larger bodies thus formed purchased for the associated societies on commission; but, following on some changes in the law brought about in I889, central purchase federations, having power to buy on their own account, and operating under commercial experts, began to be formed.

In I895 there were in Germany Io of these central co-operative purchase federations ; by I 900 the number had increased to 20 ; by 1905 to 25 ; and by the end of 1909 to 27 . The real increase, however, has been in the number, not of federations, but of " members," the latter consisting mainly of affiliated societies. Thus the membership of the federations, which stood at $\mathrm{I}, \mathrm{I} 8 \mathrm{I}$ in 1892 , rose to 2,785 in $\mathrm{I} 895$, to 7,659 in 1902 and to 10,348 in I909. The total for I909 included 4,0I4 rural banks which bought agricultural requisites for their members through the central purchase federations in the same way as the co-operative societies 
for collective purchase, the co-operative dairies and the other local bodies were doing. There are also 4,399 rural banks of the independent Raiffeisen Organisation which arrange purchases through the Central Agricultural Loan Bank. We thus get a total of 8,4 I 3 rural banks-in addition to the other organisations-affiliated to central societies for the purchase of goods, this total representing more than half of the I5,000 rural banks in Germany. At the end of Igog only I2 per cent. of the co-operative societies for purchase remained unconnected with the central purchase federations.

Included in the 10,348 members of the twenty-seven central federations are 3,787 "individual" members. These, it is explained, are mostly large farmers resident in districts where there are, as yet, no societies, or where, for some reason or other, societies cannot be formed.

The central federations act in concert with one another in making their purchases from producers or importers, and in this way they can not only give orders for exceptionally large quantities, but they have a better opportunity for overcoming the influence of traders' syndicates and combinations, and for obtaining concessions from which the smaller societies and their members directly gain. The federation of federations has, in turn, gone so far that there is an Imperial Federation of German Agricultural Co-operative Societies which at the end of Igro included :-

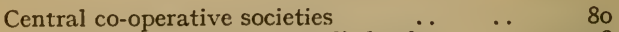

$$
\begin{aligned}
& \text { Co-operative agricultural credit banks } \quad \ldots \quad \text { 12,978 } \\
& \begin{array}{ccccc}
", & \begin{array}{c}
\text { sale and purchase societies } \\
\text { dairies }
\end{array} & \ldots & 2,194 \\
\text { Other co-operative societies } & \ldots & \ldots & \ldots & 2,050 \\
\text {. } & . & . & \text { 1,8II }
\end{array} \\
& \text { Total } \quad \ldots \quad \ldots \overline{19,113}
\end{aligned}
$$

This was an increase of 480 societies over the number for the previous year.

In Igog the purchases made by the central societies connected with the Imperial Federation, which includes 80 per cent. of the agricultural co-operative societies in the German Empire, amounted to $£ 7,397,000$. Adding to this figure the sum of $£^{2,4 I 5,000}$ expended for the Raiffeisen 
Organisation banks by the Central Agricultural Loan Bank, we get a total of $£ 9,8 \mathrm{I} 2,000$ as the value of the goods bought in a single year by the associated farmers of Germany on the principle of combination for purchase.

Detailed figures in regard to other societies affiliated to the Imperial Federation in Igog include the following :-

NATURE of Society. NUMber of SOCIETIES.

\begin{tabular}{|c|c|c|}
\hline f corn & .. & \\
\hline Milling . . & & \\
\hline Distilling & . & \\
\hline tarch factories & & \\
\hline$t$ or fruit and & veg & able: \\
\hline le of pota & $\cdots$ & .. \\
\hline egg & - & \\
\hline pou & & \\
\hline vin & prc & \\
\hline , ani & & $\cdots$ \\
\hline Animal bre & & \\
\hline $\begin{array}{l}\text { Insurance o } \\
\text { Supply of e }\end{array}$ & & .. \\
\hline $\begin{array}{l}\text { Supply of e } \\
\text { Co-operativ }\end{array}$ & & \\
\hline agricultura & & \\
\hline
\end{tabular}

NUMBER OF MEMBERS. I $2,6 I_{3}$ $\mathrm{I}, 048$ 3,218 1,056

5.345

1,308

9,484

$\mathrm{I}, \mathrm{I} 59$

5,962 22,612

3.565

In the case of most of the agricultural associations in Germany the liability of the members is unlimited, but the principle of limited liability is, nevertheless, being more and more adopted in societies created otherwise than for credit. In 1907 the number having limited liability was only II per cent., whereas by rgro the percentage had increased to $2 \mathrm{I} \frac{1}{3}$. Figures in respect to 23,737 societies on June Ist, I9Io, published in the Journal of the Board of Agriculture for July, IgI2, are as follows :-

\begin{tabular}{|c|c|c|c|c|c|}
\hline & & \multicolumn{2}{|c|}{ Unlimited Liability. } & \multicolumn{2}{|c|}{ Limited Liability. } \\
\hline $\begin{array}{l}\text { Credit Societies } \\
\text { Trading " } \\
\text { Dairy " } \\
\text { Other ", }\end{array}$ & $\begin{array}{l}\cdots \\
\cdots \\
\cdots\end{array}$ & $\begin{array}{r}\text { No. } \\
14,325 \\
1,258 \\
2,202 \\
867\end{array}$ & $\begin{array}{c}\text { per cent. } \\
92 \cdot 32 \\
55 \cdot 18 \\
66 \cdot 07 \\
31 \cdot 93\end{array}$ & $\begin{array}{r}\text { No. } \\
1,172 \\
1,019 \\
1,062 \\
1,832\end{array}$ & $\begin{array}{c}\text { per cent. } \\
7.55 \\
44.69 \\
31.86 \\
67.48\end{array}$ \\
\hline Total & $\cdots$ & 18,652 & $7^{8 \cdot 22}$ & $5,08_{5}$ & $21 \cdot 33$ \\
\hline
\end{tabular}




\section{France.}

Agricultural unions in France are mainly divided into two groups-associations and syndicates.

The agricultural associations comprise Societies of Agriculture, Agricultural Assemblies (comices), and Chambers of Agriculture. They devote their energies principally to science and research, improvement of livestock, agricultural legislation, etc. Of Societies of Agriculture there are 685 , and of agricultural comices $9 \mathrm{I} 7$.

"Syndicate" is a term which signifies, in France, not a group of financiers, as in England, but, in effect, the equivalent of our expression "trade union"; and it was under a law of March 2Ist, I884, giving the representatives of every industry in France almost complete liberty of association, that the agriculturists-who, at the last moment, were expressly included-got a charter which enabled them to organise the groups of societies, or " syndicates," comprised in agricultural organisation as developed in their country to-day.

While the industrial syndicates regarded the law of 1884 as the concession to them of the right to strike, the agricultural syndicates at first established themselves almost solely as distributive co-operative societies to which the associated farmers looked as a means of obtaining at reduced cost the requisites for their farm work. This they did more especially in the case of fertilisers, with the further advantage, in respect thereto, that the syndicate was better able to arrange for analyses and to guarantee quality; but combination for purchase of fertilisers led to similar arrangements being made also in respect to implements, machinery, seeds and breeding-stock. How the number of these syndicates has increased is shown by the following figures :-

\begin{tabular}{llllcc} 
YEAR. & & & \multicolumn{2}{c}{ SYNDICATES. } & MEMBERS. \\
I890 & $\ldots$ & $\ldots$ & $\ldots$ & 648 & 234,234 \\
1900 & $\ldots$ & $\ldots$ & $\cdots$ & 2,069 & 512,794 \\
I9I0 & $\cdots$ & $\ldots$ & $\cdots$ & 5,146 & 777,066
\end{tabular}


Of federations of agricultural syndicates there were 55 in I910, grouping 2,392 of the local organisations.

Co-operative societies for production and sale, and composed exclusively of farmers, number about 2,660 , classified as follows: Cheese-making, I,800; dairies (butter-making), 685 ; wine-making, 39; starch-making, 34 ; collective purchase and employment of agricultural machinery and implements, 23; oil-mills, 20; distilling, I7 ; milling and baking, I6 ; sugar manufacture, 8 ; fruit and vegetable preserving, 5; collective transport, $\mathrm{I}$; sauerkraut preparation, I; sale of eggs and farmyard produce, I; distilling flowers for perfumery, I; flax preparation, I; other co-operative societies, 8. Adding to these figures societies not composed exclusively of farmers, the total number engaged in production or sale is estimated at 3,260.

Agricultural credit has undergone great expansion in France of late years, mainly through the influence of State aid.

The law of 1884 prepared the way for co-operative credit banks, and the pioneer bank of this type in France was constituted in 1885 .

Increased facilities for the creation of rural banks on the Raiffeisen principle, though differing therefrom in some essential details, were conferred by the Méline law of November 5th, 1894. These further banks were to be based on the agricultural syndicates, and were to derive their members from them, but down to 1899 (when the number created was still only I36) they existed on their own resources without any credit from the State. Such resources were, however, found insufficient to allow of an expansion of the system adequate to the growing needs of rural life, and further action was considered necessary, in the special direction of State aid.

An opportunity for rendering this aid came in 1897, when the renewal by the State of the privileges conceded to the Bank of France was arranged on conditions which led to the State (I) receiving from the bank a sum amount- 
ing to $2,000,000$ francs $(f 80,000)$ a year, and (2) having placed at its disposal, without interest and up to the year I920, a sum of $40,000,000$ francs $(f I, 600,000)$, the whole to be applied to the extension of agricultural credit.

Following on these new arrangements, though not until after prolonged discussion, there was passed the law of March 3Ist, I899, which created the regional banks of mutual co-operative credit. These regional banks were to group the local banks into federations, discount their bills, and be the means of transmitting to them loans from the State funds in question to constitute their working capital. In Igor-that is, within two years of the passing of the Act-there were I6 regional banks at work, and by I9Io there were 96.

Meanwhile, various causes had led to the desire for a further extension of the credit system, among them, as set forth in the "Bulletin of the Bureau of Economic and Social Intelligence" for January, Igr2, being: (I) The newer and constantly-increasing needs of agriculture as an industry; (2) the progress made by the principle of co-operation for agricultural production; and (3) the growing necessity for small families to develop and consolidate small properties threatened by too minute a parcelling out or by the rural exodus.

So the existing system of agricultural credit at short date was supplemented by a system of long-date credit granted, under a law passed in I907, to co-operative societies, and, under another law passed in IgIo, to individual farmers.

In the former case the regional banks advance loans at the almost uniform rate of 2 per cent., and for periods not exceeding twenty-five years, to agricultural co-operative societies engaged in production, the purposes to which the loans may be applied being, however, restricted to the following: Production, manufacture, preservation or sale of agricultural commodities; acquisition, construction, installation, or adaptation of buildings, workshops, storehouses, or transport conveyances; and collective purchase 
or use of agricultural machinery and implements. Longdate loans to farmers are granted by the regional banksthrough the intermediary of the local societies - up to the amount of 8,000 francs $(£ 320)$, for the purpose of buying or improving small landed properties. The money lent is to be repaid, by annual instalments, in fifteen years.

How, under these circumstances, agricultural credit expanded in France during the period I900-10 is shown by the following figures:-

\begin{tabular}{|c|c|c|c|c|}
\hline \multirow{2}{*}{ YEAR. } & \multirow{2}{*}{$\begin{array}{l}\text { Number of } \\
\text { Regional } \\
\text { Banks. }\end{array}$} & \multicolumn{3}{|c|}{ AFFiliated Local Banks. } \\
\hline & & Number. & Members. & Loans granted. \\
\hline $\begin{array}{l}\text { r900 } \\
\text { I910 }\end{array}$ & $\begin{array}{r}9 \\
96\end{array}$ & $\begin{array}{r}87 \\
3,33^{8}\end{array}$ & $\begin{array}{r}2,175 \\
151,621\end{array}$ & $\begin{array}{c}\stackrel{f}{7_{\tilde{6}}, 000} \\
4,5^{28,000}\end{array}$ \\
\hline
\end{tabular}

The total sum which the regional banks had at their disposal in I9I0, including loans from the State, was $£ 2,287,000$, and of this amount $£ 2,017,000$ was assigned to the financing of local agricultural co-operative banks under the law of 1899 .

Down to the end of rgro long-date loans had been granted by the regional banks to productive agricultural co-operative societies, under the law of 1907 , as follows :-

Number of societies receiving loans

$\begin{array}{lllll}\text { Number of members .. } & \ldots & \ldots & \ldots & 16,497\end{array}$

$\begin{array}{llllll}\text { Paid-up capital } & \ldots & \ldots & \ldots & \ldots & £ 108,850\end{array}$

$\begin{array}{llllll}\text { Loans received } & \ldots & \ldots & \ldots & \ldots & \hbar_{1} 76,233\end{array}$

The total of I3I societies is made up thus :-

Dairies and butter factories $\quad$. $\quad$.. $\quad$.. 29

$\begin{array}{lllllll}\text { Wine societies } & \ldots & \ldots & \ldots & \ldots & \ldots & 29\end{array}$

$\begin{array}{llllll}\text { Cheese-making societies } & \ldots & \ldots & \ldots & \ldots & 26\end{array}$

Purchase and collective use of agricultural machinery and implements $\quad . . \quad \ldots$..

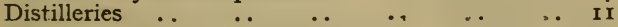

Wine and oil societies $\quad \ldots \quad$.. $\quad$.. $\quad$. 5

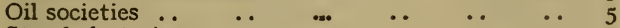

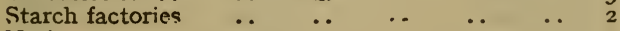

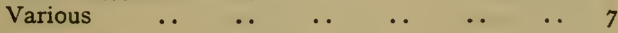

Total $\quad . \quad \ldots \quad \ldots \quad \ldots \frac{1}{13 I}$ 
The period for which, in practice, the loans are granted to the societies ranges from ten to twenty-two years; but mention is made of one small co-operative vine-growing society in the department of Var which obtained in I909 an advance of 16,400 francs $\left(£^{656}\right)$ for a period of fifteen years, and made so good a profit out of the high price of wine in IgIo that it was then able to repay the entire loan at once.

Agricultural insurance societies have greatly increased in number in France. In 1897 there were not more than $\mathrm{r}, 483$ in the country, and of these about one-half, of a rudimentary type, were in the single department of the Landes. In I9I0 there was a total of I0,73I societies, divided as follows: Cattle insurance, 8,428 ; agricultural fire insurance, 2,187; insurance against hail, 25 ; insurance against agricultural accidents, 7 ; cattle re-insurance, 58 ; fire re-insurance, 26.

Syndicates for live-stock improvement, to which the Government have made a grant of $£ 8,000$, are also being considerably extended.

The grand total of agricultural associations of all types, co-operative and non-co-operative, in France, according to the latest available returns, is 38,369 .

\section{DENMARK.}

The general position in Denmark is indicated by the following details in regard to the leading organisations in Ig09:-

\begin{tabular}{|c|c|c|}
\hline Co-OPERATIVE So & SOCIETIES. & NUMBER. \\
\hline $\begin{array}{l}\text { Dairies } \text {. } \\
\text { Bacon factories }\end{array}$ & & $\mathrm{r}, \mathrm{1} 57$ \\
\hline $\begin{array}{l}\text { Bacon factories } \\
\text { Purchase of requi }\end{array}$ & & $\begin{array}{l}34 \\
15\end{array}$ \\
\hline Export of cattle & .. & \\
\hline Export of eggs & 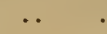 & \\
\hline Horse-breeding & .. & 270 \\
\hline Cattle-breeding & .. & 1,260 \\
\hline Pig-breeding & .. & \\
\hline Sheep-breeding & .. & 102 \\
\hline Controi societies & .. & sig \\
\hline Total & .. & 3,610 \\
\hline
\end{tabular}

MEMBERS.

I 57,000

95,000

65,000

8,400

52,000

$2 \mathrm{I}, 500$

31, 300

6,430

850

12,000

449,480 
In respect to dairies it might be mentioned that, in addition to the I,I57 co-operative, there were $238 \mathrm{com}$ mercial, and 90 estate, dairies. Out of 183,313 holdings, with $1,282,254$ cows, in Denmark, I54,568 holdings, with I,059,956 cows, were associated with the co-operative dairies.

About 880 dairies, mostly of the co-operative type, have combined to form twenty-one unions for the development of the industry through lectures, exhibitions, and other means; and twenty of the twenty-one unions have formed two federations which, in agreement with the union not connected with either, have appointed a committee to watch over common interests. The dairy unions also appoint " juries" of experts to test the milk supplied and endeavour to keep up its quality.

Some 840 of the dairy societies were, in r9o9, affiliated to a Collective Purchase Federation formed in Igor to enable the Danish dairies to obtain their machinery and other requisites under the most favourable conditions. The business done by this federation in Igog amounted to EI05,000.

For the export of butter there are federations of dairies whose officers devote themselves to the sale of butter independently of middlemen. There were, in I909, six of these federations, operating on account of 225 co-operative dairies, and the business done by them amounted to about $£ I, 758,000$.

Almost all the butter exported comes to the United Kingdom. The total quantity we received from Denmark in IgII was over 85,000 tons, valued at $£$ I0,500,000.

How the co-operative bacon factories have increased in number and in the amount of business done by them may be shown thus :-

NUMBER OF

YEAR. I 888

1890

1900

I 909
FACTORIES.

.. I

.. I0

.. 26

-. 32
Number of Pigs

SLAUGHTERED.

23,400

I 47,500

675,200

I, 362,500 
In addition to these co-operative bacon factories there are about twenty private ones working for exportation, and slaughtering 500,000 pigs in the year.

Co-operative societies for purchase are of the greater importance in Denmark on account of the necessity for importing large quantities of grain and feeding stuffs for livestock, the home supplies being wholly inadequate. In Igog the total purchases of the fifteen societies specially established for this purpose (apart from what is done in the same direction by other societies) amounted to $£ \mathrm{I}, 736,000$, of which sum about $£ I, 500,000$ was for grain and feeding stuffs, the remainder being for seeds and chemical manures.

Egg-export from Denmark is in the hands mainly of two large federations-the Danish Co-operative Society for the Export of Eggs, established in I895, and the Esbjerg Butter Packing Company, which began to export eggs in I899and seven co-operative bacon-curing factories. The system adopted for obtaining the eggs is based on the organisation of collecting centres, of which the Egg-Export Society has 550 , with a membership of 43,000 , the business done by this one society alone in Igog amounting to $£ 253,000$. The Esbjerg Company has 300 collecting centres. The total value of the eggs exported from Denmark in Igog was £505,000.

The Control Societies keep an account, in the case of each cow registered, of (I) milk yield, (2) proportion of butter-fat in the milk, and (3) the relation between yield and fodder, thus giving the farmer valuable information as to the stock specially suitable for breeding. They were first established in Denmark in I895. The number of cows registered in I 909 was 206,800 . Various forms of agricultural insurance -including fire, storm, hail and live-stock insurance-have also been developed.

\section{Holland.}

"Marvellous" is the phrase applied to the advance of agricultural organisation in Holland.

For the actual beginnings of the movement there we have 
to look, as in the case of other European countries, to the agricultural crisis that began to be felt about the year I88o. The changes in production, the competition of foreign supplies, the cheapening of sea transport and the altered conditions of international trade first brought home to the minds of the Dutch peasantry the need for association, while later on this need was emphasised, in their case, by the fact that certain producers in Holland were causing a bad name to be given to Dutch produce by reason of the inferior qualities thereof they were then sending to foreign markets.

It was, however, not until about 1890 that the movement began to be taken up in Holland in real earnest. Among the peasantry the idea of co-operative action in agricultural production and sale was, down to that time, almost unknown. All the same, it is mainly to the Dutch peasantry that the subsequent rise and expansion of the said idea in their country are due. The main lines of policy adopted by the Dutch Government were those of, first helping to propagate the principle of co-operation, and then leaving to the societies the fullest possible choice in deciding for themselves the form of their constitution according to one or other of four different methods of association sanctioned by the laws of Holland. The Government have also in recent years given small subventions in support mainly of credit and cattlebreeding societies.

So well has the movement spread in this short period, and under these particular conditions, that to-day the number of co-operative agricultural societies in Holland is I,34I, with a membership of about 135,000 .

Co-operative credit societies of the Raiffeisen type, and forming dependencies of three central banks, whose headquarters are at Utrecht, Eindhoven and Alkmaar, have more especially undergone a remarkable growth, the 46 banks, with 2,50I members, in I899 having increased to 582 banks, with 40,840 members, by 1909 .

Co-operative purchase, mostly in regard to fertilisers and concentrated foods for cattle, is carried on by the agricultural 
societies; but, though the societies are grouped in federations, the rule in Holland is for each branch to make its own purchases, independently of the federation.

Co-operation for sale is chiefly organised in connection with vegetables and fruit, of which very considerable quantities find their way to the English market. The organisation is carried out by local horticultural societies, some 250 in number, and of these no fewer than 80 have established public sales of the produce of their members.

Co-operation for butter production has been developed so far that there are now 686 co-operative dairies, of which 358 are worked by steam-power and 328 by hand. The majority are grouped in seven federations centralising purchase of necessaries, and in some measure also regulating the butter production, while the quality of the butter is guaranteed by a "Control" system which, while due to private initiative, receives a subvention from the State.

Other co-operative societies in Holland deal with stockbreeding and agricultural insurance.

\section{BELGIUM.}

In Belgium, as shown by the latest available figures, for I909, agricultural organisation would seem to have spread throughout the country with such thoroughness as to cover every possible interest.

Of the agricultural comices, which hold shows and exhibitions, carry on experimental farms, and answer mainly to our own type of agricultural societies, there were in Igog a total of 160 , with nearly 38,000 members, and they held in that year 6 district and 96 cantonal shows.

Agricultural "leagues" in Belgium are mostly village or communal organisations corresponding to our agricultural co-operative societies. They generally start with collective purchase of farm requisites, and afterwards occupy themselves with credit, insurance, live-stock improvement, etc. furthering these aims by affiliation with a cantonal, regional or national federation. The total number of leagues in 
Ig09 was 1,093 , and their membership was 71,395 . The I 85 horticultural societies, with a membership of 29,000 , complete their organisation with a series of regional federations, which, in turn, select delegates to a National Committee for the progress of horticulture.

Societies for the purchase of seeds, manures, foodstuffs and machinery (including the purchase sections of the comices and leagues) number I,I23, with a membership of 70,208 . Their purchases in I909 amounted to nearly $£ 7$ I8,000.

Of co-operative dairies in actual working in Belgium in I 909 there were 521 . These had 56,805 members, possessing I62,000 cows, and the total sales for the year amounted to

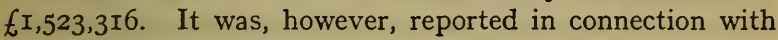
a National Dairy Congress held at Brussels in IgII that the general condition of the co-operative dairies in Belgium was not satisfactory. For four or five years the position had remained stationary, and in many provinces there was even a considerable decline. One authority at the congress, M. Collard Bovy, attributed such decline to bad organisation and bad management, while economically, he said, " no attention had been paid in Belgium to the fact that buttermaking was the least remunerative part of dairying, and that cheese-making and various other subsidiary industries which, under the guidance of technical advisers, might be developed in connection with the dairies, would be more lucrative."

Apart from dairy produce, several systems of co-operation for sale have been established, though societies which do not also engage in the purchase of requisites are said to be far from flourishing. Among the sale societies are 73 of beetroot-planters, described as " rather leagues of defence against the sugar manufacturers."

Of cattle-breeding societies there were 447 in I909. They had 18,705 members, and the number of cattle registered on the books of the societies was 56,727 . Goat-improvement societies numbered 425 , with 40,260 members, possessing 48,505 goats; pig breeders had formed I9 societies, with 
48,505 members; and there were also 56 rabbit-improvement societies, with $\mathrm{I}, \mathrm{I} \mathbf{6}$ members. Poultry societies totalled I48, with 6,820 members; and of bee-keepers' societies there were I97, with 5,032 members.

The I,I42 voluntary cattle-insurance societies had IOr,700 members on December 3Ist, I909, and the number of cattle insured was 294,583 . There are also horse, goat, and pig insurance societies.

Raiffeisen banks in Belgium numbered $6 \mathrm{I}_{4}$ in I908. They are grouped into regional federations, forming seven central banks. These central banks are the intermediaries through which the General Savings Bank can, in accordance with the powers granted to it, distribute credit to the rural banks, the central banks in turn guaranteeing the engagements of the local banks with the General Savings Bank. They also control the local banks and receive the surplus funds of some in order to grant loans from this source also to others. The loans to members of the rural banks amounted in I 909 to $£ 373,900$.

An especially important feature of the situation in Belgium is afforded by the great federations with which the smaller societies are almost invariably connected.

To the federation known as the "Boerenbond," founded in I89o by the Abbé Mallaerts, "Father of the Peasants," there are now affiliated 53I local associations, with 44,500 members. It claims to have undertaken the threefold mission of $(I)$ the defence of the religious, moral and material interests of the peasants; (2) the promotion of agricultural legislation; and (3) the advance of agricultural organisation ; and in the carrying out of this programme it seeks to interest itself in everything that concerns agriculture and the agricultural community. Among other things it publishes reviews, arranges lectures, holds conferences, conducts departments for collective purchase and sale, has a laboratory for the analysis of agricultural commodities, equips and inspects dairies, supplies agricultural machines, creates credit societies, organises agricultural insurance, holds holiday courses for managers and others connected with 
agricultural concerns, gives legal assistance, watches over the management of affiliated societies, affords expert guidance in cattle-breeding, interests itself in farm-women's clubs, seeks to check the exodus from the country districts, and does good work in many other ways besides.

Purchases made by the federation in IgIo, on account of its branches, included the following: Fertilisers, $£^{6} 6,334$; feeding stuffs, $£ 352,328$; seeds, $£ 5,670$; and agricultural machinery, $£ 3$,or6.

Of Raiffeisen banks affiliated to the Boerenbond in 1909 there were 297, with 2I,495 members.

The Agricultural Federation of East Flanders, founded in I89I, comprises 275 societies, with over 30,000 members. Constituting the head-quarters of all agricultural co-operative work in the province, it occupies itself with every agricultural interest, and carries on an active propaganda by means of pamphlets and a publication of its own, but more especially by frequent lectures.

West Flanders has also an Agricultural Federation of 72 societies, with over 7,000 members. In addition to collective purchase, the Federation organises about Ioo lectures annually, publishes a weekly organ, issues to members a weekly bulletin giving current prices of fertilisers and feeding stuffs, conducts a students' club for dairy managers, and organises credit, insurance, live-stock, dairy and other co-operative societies.

Farm-women's Clubs were started in Belgium in I905 by M. de Vuyst, Inspector-General of Agriculture, who, inspired by what he had seen of Women's Institutes in Canada, established at Leuze, on kindred lines, an organisation which was the first of its kind on the Continent of Europe. In I910 there were 75 of these clubs in Belgium, with a membership of 7,000 .

M. de Vuyst says, in a book he has published on "Le Rôle de la Fermière" (Brussels: Albert de Wit), that the main object of the clubs is to keep fresh the knowledge acquired in the agricultural schools, and to enable their members to become acquainted with the new processes introduced by 
agricultural science. In effect, however, the clubs concern themselves with the whole range of women's interests and duties both on the farm and in the home. The clubs have their libraries of books relating to agriculture, dairy work, poultry farming, domestic economy, health, etc.; they hold meetings at which addresses on a wide variety of subjects are given, the aggregatc attendance at these gatherings in I909 being over 12,000 ; they train women lecturers; they arrange visits to model farms, and they also organise shows, with a view to extending knowledge of the best methods of cultivation of stock, poultry breeding, or dairy management; while their various aims and objects are further fostered by the publication of periodicals dealing with women and country life in general.

In I909 a regional congress, attended by representatives of 60 clubs, was held at Namur, and in IgII the whole of the clubs established by women relatives of members of local societies affiliated to the Boerenbond grouped themselves into a federation which now constitutes one of the departments of that great organisation.

\section{BRITISH INDIA.}

Co-operative credit is the form of agricultural co-operation which has hitherto mainly been developed in British India, and even in this respect the progress made has been primarily due to State action.

India, with its bureaucratic Government, and with its many races of people of varying types of civilisation, differs materially from countries possessing representative Governments and having populations more likely to resort on their own account to organised effort for the obtaining of common economic advantages. Yet though the said bureaucratic Government has taken the initiative, it does not propose to adopt more "spoon-feeding" than may be absolutely necessary. According to Bulletin No. 3 of the Bureau of Economic and Social Intelligence, the Government has set itself the task of teaching the population of India the principles of co-operative credit, and also-while exercising no 
compulsion-of promoting the formation of credit societies, and guiding them in their work. But the Government, we are further told, " has recognised that its task is something more than this. It is its policy to create a popular movement, and gradually to convert the initiative of the State into active propaganda conducted by the people of India themselves, and even, as far as possible, to place the work of financing and supervising the societies in the hands of popular organisations."

As for the results, Mr. Henry W. Wolff, in the third edition of his book on "People's Banks," declares that " the opportunities furnished by the banks have whetted the popular appetite for more productive methods of husbandry "; that "the seed of co-operation has in India fallen upon good ground"; and that "the progress made is quite phenomenal."

This last-mentioned expression is fully warranted. The Co-operative Credit Societies Act, laying down the broad outlines of the system of co-operative credit to be promoted in the various Provinces of India, was not passed until I904, and in March 1905, there were in India only 35 rural and six urban credit societies; yet the position in I9IO-II, as shown by figures published in the "Statement Exhibiting the Moral and Material Progress and Condition of India during the year IgIo-II," issued from the India Office, was as follows :-

\begin{tabular}{|c|c|c|c|}
\hline Societies. & Number. & Membership. & $\begin{array}{l}\text { WORKING } \\
\text { CAPITAL. }\end{array}$ \\
\hline $\begin{array}{l}\text { Central } \\
\text { Urban... } \\
\text { Rural .. }\end{array}$ & $\begin{array}{r}59 \\
368 \\
4,894\end{array}$ & $\begin{array}{r}5,682 \\
62,598 \\
236,778\end{array}$ & $\begin{array}{c}t \\
331,600 \\
291,900 \\
730,200\end{array}$ \\
\hline Total & 5,321 & $305,05^{8}$ & $\mathrm{r}, 353,700$ \\
\hline
\end{tabular}

The central societies here referred to comprise (I) central banks, which exist primarily for the purpose of financing 
affiliated societies; and (2) central unions, which are federations for the purpose of inspection, control and mutual guarantee. In some instances, the functions of a central bank and a central union are combined in a single body, known as a central banking union. The central and urban societies are based on limited liability. Rural societies work with unlimited liability, " a principle," we are told, "which has no terror for the ryot, who has long been accustomed to it in his family relations." The chief purposes for which loans are obtained from the rural banks are purchase of cattle, payment of land revenue, and repayment of loans from money-lenders. Smaller sums are also advanced for non-productive purposes, such as expenditure on marriage and other ceremonies.

Of the $£ 730,000$ working capital of the rural societies, $£ 466,000$ represents loans from non-members and other societies, £96,000 share capital, £I05,000 members' deposits, $£ 23,000$ reserve, and $£ 40,000$ loans from Government. The financial support of the State is, however, being gradually withdrawn. In several provinces State loans have been altogether discontinued. "The movement has almost everywhere passed out of the experimental stage ; many of the societies are self-supporting and are winning more and more the appreciation and confidence of the people."

While agricultural organisation has thus far developed in India mainly on the lines of co-operative credit, the "statement " further says :-

Co-operative societies for productive and distributive purposes exist, but not as yet in any numbers. Some of the rural credit societies, however, have extended their activities in these directions: they market the produce of their members, purchase agricultural machinery for their use, etc. The Provincial Agricultural Department finds these societies admirable intermediaries for the propagation of improved methods of cultivation.

JAPAN.

The example of Japan is especially interesting as that of a nation which, having resolved to adopt "all modern 
improvements," in the way of social and economic progress, has naturally resorted to the main principles of agricultural organisation, and has also developed them at a rate and with a comprehensiveness hardly to be surpassed elsewhere.

This latter fact is well brought out by the following Table, which gives the total number of agricultural co-operative associations in Japan in the years mentioned :-

\begin{tabular}{lr|cc} 
YEAR. & NUMBER. & YEAR. & NUMBER. \\
I900 & 21 & 1905 & 1,671 \\
1901 & 263 & 1906 & 2,470 \\
1902 & 512 & 1907 & 3,363 \\
1903 & 870 & 1908 & 4,361 \\
1904 & 1,232 & 1909 & 5,149
\end{tabular}

The figures for I909 give the position on June 3Ist, whereas the others are for December 3Ist in the years mentioned. The former thus show an increase for six months only. The total of 5,I49 is made up thus :-

\begin{tabular}{|c|c|c|c|c|c|c|c|}
\hline \multicolumn{6}{|c|}{ Societies. } & \multicolumn{2}{|c|}{ NumbEF } \\
\hline Credit & . & . & . & . & . & .. & 1,864 \\
\hline Sale... & .. & .. & . & .. & .. & .. & 187 \\
\hline Purchase & .. & .. & .. & .. & .. & .. & 744 \\
\hline Production & & .. & .. & .. & .. & .. & 64 \\
\hline Sale and $\mathrm{p}$ & urchase & & .. & .. & . & . & $44^{\circ}$ \\
\hline Sale and $p$ & roducti & & .. & .. & .. & .. & II 3 \\
\hline Purchase a & and pro & duction & & . & . & .. & $4^{8}$ \\
\hline Sale, purch & hase an & d prod & uction & .. & .. & . & 200 \\
\hline Credit and & sale & .. & .. & .. & .. & .. & 29 \\
\hline Credit and & purcha & ase & .. & .. & . & .. & 699 \\
\hline Credit and & produc & ction & & .. & .. & . & 8 \\
\hline Credit, pur & rchase a & and sal & & .. & .. & .. & 538 \\
\hline Credit, pur & rchase a & and pro & oductior & & .. & . & 18 \\
\hline Credit, sale & $e$ and $p$ & oroduct & ion & & .. & . & 3 \\
\hline redit, sale & e, purch & hase an & ad produ & uction & .. & $\cdots$ & I94 \\
\hline & & & otal & .. & .. & $\cdots$ & 5,149 \\
\hline
\end{tabular}

The estimated number of members of these societies on June 3oth, Igog, was 445,092 .

As indicating the eagerness of the Japanese to profit by the experience of other nations, it might be mentioned that, at the request of the Central Association of Japanese Agriculturists-a like request subsequently being received from the Home Department of the Bureau of Local Affairs, Tokyo-the author of "The Organisation of Agriculture" 
assented to the translation of his work into Japanese, and he has since been officially informed that copies of the book, in that language, have been circulated among the local authorities in Japan.

\section{The United States.}

Agricultural organisation and agricultural co-operation have alike been developed in the United States under conditions peculiar, to a certain extent, to that country, yet with such success that, although definite figures are lacking, competent authorities estimate that the total number of societies there is about 75,000, while the total membership is put, approximately, at $3,000,000$. The distinction between "organisation" and "co-operation" is not always clear, while a good deal of agricultural organisation is to-day being developed, or projected, in the United States on capitalist rather than co-operative lines; but in either case the fundamental principle of, at least, combination in agriculture is involved.

At first there was a reproduction of the ordinary type of agricultural societies familiar to European states, and these, with their spread of scientific or technical knowledge, their stock improvement and their shows, etc., did much good in the days when agriculture in the United States was still comparatively undeveloped, and provided mainly for local markets.

Then the farmers began to combine on a much broader basis for the attainment of legislative and other advantages.

They created a " Farmers' Alliance " which seemed likely to become a powerful body, and might have done so but that it collapsed because it was unduly political. Permanent success was, however, gained by what is known as the "Grange" movement.

Originally founded in 1867 , this further movement aimed at advancing the general interests of farmers in almost every phase of their activities, included therein being the popularisation of agricultural science, the formation of co-operative agricultural societies, the improvement of 
agricultural production, combination for sale, tariff, sanitation and other legislative questions, and problems of national life in general. The basis of the organisation is formed by local Granges. These "secret societies " (for such they are in effect, being somewhat akin in their working to the Freemasons' societies) elect representatives to County Granges which, in turn, send delegates to State Granges, and these, again, choose the members of a National Grange, whose annual congress is the equivalent of a Farmers' Parliament for the United States, and is the most influential body of agriculturists in that country.

In regard to the various phases of agricultural co-operation in the United States, it is a noteworthy fact that while there has hitherto been comparatively little development of the principles either of agricultural credit or of collective purchase, which have been primary causes for the spread of agricultural co-operation in many other countries, there has been a remarkable expansion of that principle of combination for sale which elsewhere has been regarded as the particular form of the general movement that presents greater difficulty than any other.

It is in the western States, in connection with the fruit industry, that co-operation for marketing has undergone the greatest degree of expansion. A variety of causes have contributed to this result, among them being (I) the fact that the great production of fruit-more especially in California-made it necessary that markets should be sought, not alone in other States, but in other countries; (2) the need for having as full and complete a knowledge of these markets as possible; (3) the necessity for consigning to them under such conditions as not only to secure the best terms for transport, but also to guarantee the sending of produce in large quantities of uniform qualities, and likely, therefore, to secure uniform prices; and (4) the obvious advantage in having all these things done through powerful co-operative societies, each acting for a large group of growers, instead of leaving every individual among them to make the best terms he could with the middlemen who had 
previously controlled the situation, and this, too, with such monopolistic tendencies that a desire to escape from their "exaggerated claims" is said to have been one of the primary reasons for the eventual resort to the system of organisation for sale.

Upon how big a scale some of these societies operate may be shown by a few facts concerning the California Fruit Growers' Exchange.

This central body, the headquarters of which are at Los Angeles, is elected by fourteen district associations, themselves representing about roo local societies of fruit-growers. The local societies collect the fruit from their associated members and see to the packing and the forwarding of it, in complete truck loads, to one or other of seventy-five paid agents established near the chief markets of the United States and Canada, or in London. In the event of the producer not having specified (as he is at liberty to do) to whom his consignments are to be delivered, the agents arrange the sale and get the best possible terms. At Chicago and Omaha there are general agents who direct the operations of the local agents and keep in close touch with the markets, advising daily by telegraph or telephone. Information as to markets is also regularly supplied by the staff of agents.

In I909 the number of fruit-growers connected with this one organisation was between 10,000 and 12,000 ; the consignments of fruit made by the society amounted to I $4,500,000$ boxes; the accounts showed an aggregate profit of $£ 4,575,000$, while in addition to the increased net returns in the price of their products the growers saved about 50 per cent. in their expenses as compared with what their expenditure would have been under former conditions.

Another society, the Peninsular Products Exchange of Maryland, which does an annual business of about $£ 400,000$, is said to spend $£ 2,000$ a year on gaining information as to the different markets.

In co-operative production the chief success attained in the United States has been in regard to co-operative dairies. 
The total number is about $x, 900$, and the value of the output of those in the central northern region, particularly in the State of Minnesota, is alone put at about $£ 6,000,000$ a year.

Then the American farmers, finding, as is said, that the struggle against the "tyranny" of the commercial interests controlling the grain elevators near the railway stations in the central and western regions was " a matter of life and death to them," formed co-operative societies and erected elevators of their own; they have their co-operative societies for life insurance and sickness insurance; they overcame the difficulties which arose in the insuring of farm property or farm produce through the ordinary companies by forming societies for co-operative fire insurance; they have adopted a system of co-operative telephones, one society alone having 760 miles of telephone line; they have organised co-operative live-stock associations with a view to making a particular township or county noted for the production of some special breed or breeds of cattle, and they have also established societies for the "control" of dairy cattle.

In addition to the furthering of these various economic interests, rural betterment and the revival of country life are aspirations which have been especially cherished in the United States. The agricultural societies associated with the Grange movement sometimes unite in district or even in State federations, to which the name of Leagues for Rural Progress is given. The object of a representative body of this type, The New England Conference for Rural Progress, is said in the rules to be " to promote the interests of agriculture and of rural life in the New England States by securing the co-operation and federation of the various State and inter-state organisations and agencies which are working for rural betterment and agricultural advancement in New England."

A more important development in this direction came, however, with the appointment, in I908, by President Roosevelt, of a commission to study the urgent problems of 
American rural life. In his letter of instructions to the members of this commission Mr. Roosevelt said :-

In the United States . . . the farmers in general are better off to-day than they ever were before. . . . But practically the whole of this effort has hitherto been directed towards the increasing of crops. Our attention has been concentrated almost exclusively on getting better farming. .... Agriculture is not the whole of country life. The great rural interests are human interests, and good crops are of little value to farmers unless they open the door to a good kind of life on the farm.

This problem of country life is in the truest sense a national problem. . . . The farmers have hitherto had less than their full share of attention along the lines of business and social life. There is too much belief among all our people that the prizes of life lie away from the farm. I am, therefore, anxious to bring before the people of the United States the question of securing better business and better living on the farm, whether by cooperation between farmers for buying, selling and borrowing, by promoting social advantages and opportunities in the country, or by other legitimate means that will help to make country life more gainful, more attractive, and fuller of opportunities, pleasures and rewards for the men, women and children on the farms.

Among the recommendations made in their report by the members of the commission was one that- "Before all things an efficient movement in favour of co-operation among the farmers is to be desired, to put them in a position to sustain the struggle against the other economic classes they have business relations with."

On the question of co-operative agricultural credit mention has already been made of the fact that hitherto little advance has been made in the United States ; but there is gratifying evidence that the financial interests there are preparing to recognise more fully the claims of agriculture to their own encouragement and support, the subject of "Agricultural Development and Education," introduced by Mr. George E. Allen, educational director of the American Institute of Banking, having been one of the matters discussed at a convention of the New York State Bankers' Association held at Buffalo on June I3th and I4th, IgI2.

In anticipation of this discussion, and in view of the 
possibility of some action being taken by the Association to encourage agricultural development in New York State, several articles on the subject were published in the issue of Moody's Magazine for June, IgI2, among them being one on " The Importance of Improved Agriculture: The Banker's Opportunity," by Mr. W. C. Brown, President of the New York Central Railroad. Commenting especially on the failure in the United States to increase the production of the nation's farms by increasing the number of bushels per acresuch failure being attributed to " careless, uninformed methods of seed selection, fertilisation and cultivation "Mr. Brown said that the railroads, both in the east and the west, were co-operating with the State agricultural colleges and other institutions having departments of agriculture in running trains and arranging meetings of farmers for the purpose of preaching the great gospel of better methods, which also meant more profitable farming; but no organisation, he declared, could wield a more potent influence in stimulating and directing this movement than the New York Bankers' Association. He especially advised them to-

Lend money liberally, if assured that it will be used intelligently and economically in increasing the productivity of the farm by drainage and by fertilisation; because these things will double the value of the farm, double the prosperity of the community, and in turn double the deposits and increase the dividends of your bank.

While public authorities, experiment stations and agricultural colleges can contribute much in the way of stimulating interest in this agricultural awakening by disseminating accurate knowledge and the results of scientific research, the most important feature of the work is personal counsel and advice from those who thoroughly understand its economic significance and in whose judgment the farmers are accustomed to place most confidence. No body of men is so favourably situated, or is better equipped by experitence and influence to further this movement than the bankers of this State.

To take advantage of this opportunity is to exercise constructive statesmanship of the highest order; and the imagination can conceive of no higher duty, no broader patriotism, and no more far-reaching philanthropy, than to take part in this vitally important work.

In the further issue of Moody's Magazine for September, 
I9I2, there was published an article on "Banks for the Farmer," by Mr. Myron T. Herrick, the American Ambassador to France, preceded by an editorial Note stating that Mr. Herrick " has been making a special study on behalf of the United States Government of the farm financing systems of Europe with the object, we understand, of assisting in the preparation of legislation for the introduction of similar systems " in the United States. It is further mentioned in the Note that Mr. Edwin Chamberlain, of the American Bankers' Association, was returning from Paris in order to address the Savings Bank Section of that Association at Detroit, on September I2th, on " European Land and Rural Credit Facilities."

\section{Mr. Herrick says in his article :-}

The course of the industrial development of the United States thus far has been such as to stimulate the growth of urban population, partially at the expense of the rural districts, until the overcrowding in our cities has become a matter of serious concern. The pressure of population in the cities has materially lowered the standard of living of large numbers of people whose ability to participate intelligently in the industrial and political affairs of the community is thus lessened. On the other hand rural life provides the proper environment for the development of a high order of manhood and womanhood. The tendency of farm life is to produce a virile citizenship-a class of men and women who are actively responsive to their civic duties. It is, therefore, of the greatest possible importance to the social, political and economic welfare of the country that everything possible be done to promote its agricultural interests.

Heretofore, he proceeds, the conditions of the United States have been so favourable to farming that agriculture has been regarded as an industry needing little consideration, the necessity for the wise development and conservation of agricultural resource being overlooked in the eagerness to attain commercial and industrial supremacy. The availability of virgin fertile land made the farmers careless in their methods; but the time has come when there must be adopted methods of cultivation that will yield the greatest amount consistent with economical production. $\mathrm{Mr}$. Herrick gives figures from the United States census of IgIo 
to show the present unsatisfactory, if not actually " alarming," status of agriculture there, and he proceeds :-

Much is now being done by the National Government, the States, various associations and individuals to diffuse and magnify the interest in farming, to disseminate technical knowledge of agriculture, to encourage higher standards of cultivation, to eliminate waste, and to make rural life more attractive. All this is excellent and necessary, but it also is essential to provide some means by which farmers can secure at low rates the funds they need to increase the productivity of their land ; otherwise, much that is being done to educate farmers in scientific methods will be without practical result.

Some of the older countries, France and Germany, for instance, not only taught their farmers how to make their land yield maximum crops but set up the financial machinery by which they could borrow easily and cheaply the money they need to put into operation the things that are taught ; and-

The history of agriculture in France, Germany and other countries proves conclusively that one of the essential factors in the development and maintenance of scientific farming is the existence of facilities whereby landowners can obtain funds on favourable terms... Whatever else may have been done in France, Germany and other countries to raise the standard of farming, it is clear that little would have been accomplished had the financial needs of farmers been ignored.

Mr. Herrick comments on the disadvantages under which the American farmer suffers when in need of funds by the use of which the output of the farm can be increased; he gives details as to what is being done on the Continent of Europe to develop agricultural credit, and concludes :-

The details of the organisation of these societies and companies have been fixed by the social and economic conditions of the country in which they are located, but American ingenuity surely is equal to the task of elaborating and of adapting to conditions here the principles that underlie the foreign agricultural credit institutions. An intelligent regard for the future status of agriculture in this country, and, by consequence, of social and economic progress demands that well advised and active measures be taken to perfect arrangements whereby farmers, to finance legitimate operations, may have access to the broad, steady security market now open only to municipalities and to large industrial and railroad corporations. Fortunately, the necessity of having cheap money to finance scientific farming is widely 
recognised. Both the Republican and Democratic national platforms of this year very properly recommend and urge the investigation of foreign agricultural credit organisations as a basis of legislation in this country.

\section{An International Federation.}

Down to 1904 the agricultural co-operative societies of Europe in general were content to discuss questions of international policy through the International Co-operative Alliance, which deals with co-operation in all its various phases in the different countries of the world. At the Buda Pest Congress of the Alliance, however, held in the year mentioned, the representatives of the German and Austrian rural co-operative societies dissented from the passing of a resolution hostile to the granting by the State of financial aid to co-operative undertakings, and they carried their dissent so far as to withdraw from the Congress altogether. Three years later, on the initiative of the Imperial Federation of German Agricultural Societies, there was formed at Lucerne an International Confederation of Agricultural Cooperative Societies which was to consist exclusively of national federations of co-operative agricultural societies and deal only with the special interests of that type of organisation.

The new body held congresses at Vienna, in 1907 , and Piacenza, in I908, to discuss matters of policy, and by the end of rgro it had received the adhesion of national or central federations in the following ten countries:-Germany, France, Austria, Hungary, Italy, Holland, Switzerland, Bulgaria, Servia and Finland. These national federations represent a total of no fewer than 33,000 agricultural co-operative societies.

At the conferences already held by the Confederation the subjects discussed have mainly related to co-operation for production, sale and credit, and the lines of both national and international policy that should be taken thereon. In regard to production attention was called to the fact that the manufacture of fertilisers by agricultural co-operative societies had assumed large proportions in Italy, and the 
suggestion was made that co-operative factories of the same kind in various countries should make such mutual arrangements as would facilitate the sale of their output, and give to the co-operative societies in general a still greater degree of independence in providing for the needs of their members, The view adopted, however, was that, while it certainly was desirable that the different countries should exchange experiences, with the object of concerting measures in common to counteract the action of trusts or combinations likely to be hostile to agriculturists, it was not at present expedient that the societies should enter on the risks and uncertainties of international co-operative trading.

It was further suggested that steps should be taken by the Confederation to facilitate the interchange of capital between rural credit societies and other agricultural co-operative bodies, both nationally and internationally; and though difficulties in the way of international action were once more foreseen, the fact that the proposal was brought forward at all is further suggestive of the direction that is being taken by the minds of leaders of agricultural organisation on the Continent of Europe.

\section{INTERNATIONAL INSTITUTE OF AGRICULTURE.}

How universal are the efforts now being made to place the interests of agriculture on a sounder scientific and economic basis can best be shown, perhaps, by some further details respecting the International Institute of Agriculture, to which reference has already been made.

The Institute was established, with headquarters at Rome, under an International Treaty, dated June 7 th, I905, in order, among other things, " to study questions concerning agricultural co-operation, insurance, and credit in all their forms, and to collect and publish information which might be useful in the various countries for the organisation of agricultural co-operative insurance and credit institutions." The Treaty was ratified by forty Governments, and ten others have since given in their adhesion. Bulletins are published by the Institute on "Agricultural Statistics," 
"Agricultural Intelligence and Plant Diseases," and " Economic and Social Intelligence," while the various other works issued by the Institute include the first of two series of "Monographs on Agricultural Co-operation in Various Countries." A former member of the staff of the Agricultural Organisation Society, Mr. J. K. Montgomery, B.A., B.Sc., is a member of the literary staff of the Institute's Bureau of Economic and Social Intelligence. The full list of States adhering to the Institute is given in the official list in the following order:-Germany, Argentine Republic, Austria, Hungary, Belgium, Brazil, Bulgaria, Chile, China, Costa Rica, Cuba, Denmark, Ottoman Empire, Egypt, Ecuador, Spain, United States, Ethiopia, France, Algeria, Tunis, Great Britain and Ireland, Australia, Canada, British India, New Zealand, Mauritius, Union of South Africa, Greece, Italy, Eritrea and Italian Somaliland, Japan, Luxemburg, Mexico, Montenegro, Nicaragua, Norway, Paraguay, Holland, Peru, Persia, Portugal, Roumania, Russia, Salvador, San Marino, Servia, Sweden, Switzerland, Uruguay.

The MORAL FOR OURselves.

Co-operation in agriculture has hitherto been so widely associated mainly with Denmark that many English people have failed to realise the extent to which the fundamental principles involved have already spread throughout the world, however much the application thereof may vary according to the national circumstances or conditions of the lands concerned.

It has here been sought to show (I) what these fundamental principles are, and, (2) by a few typical examples, how they are being applied abroad in actual practice; and the moral we are left to draw is that when so many other countries are seeking to re-establish their agricultural, their economic and their rural conditions on a firmer and better-organised basis, it is incumbent upon ourselves not to fall behind in the march of the nations along these allimportant lines of material and social progress. 


\section{CHAPTER III.}

\section{THE POSITION AT HOME.}

IN order to appreciate more fully the significance for ourselves of the agricultural organisation movement which is thus spreading throughout the world, it is desirable to obtain a clear idea of the position that agriculture still occupies among our national enterprises, notwithstanding all that has been said concerning agricultural depression, the decline of agricultural population, and the comparatively greater advance of textile and other industries.

\section{AGRICULTURE AS AN INDUSTRY.}

As regards persons employed in the United Kingdom, figures given in the Board of Trade (Labour Department) Abstract of Labour Statistics [Cd. 6228] show that in Igor the premier position was still occupied by agriculture, the total number of persons employed therein, as compared with the figures for various other leading industries, being as follows :-

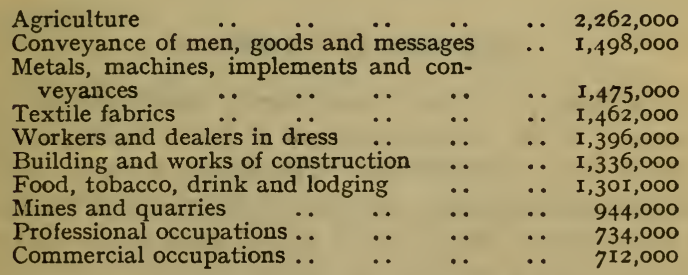

In the Board of Agriculture and Fisheries Report on the Agricultural Output of Great Britain (IgI2)-dealing with 
the result of enquiries made in connection with the Census of Production Act, I906-the number of persons permanently employed, throughout the year, on the farms of Great Britain only, and excluding all holdings of one acre or less, is given for 1908 as $1,673,000$, divided into 500,000 occupiers and $I, I 73,000$ permanent labourers. In addition to this total, however, one must take into account the considerable number of persons temporarily employed at various seasons of the year, as pickers or otherwise. The number of " hoppers," for instance, is estimated at I6r,000.

Large, again, as are the figures in regard to the number of those " employed on agriculture," as such, one must further bear in mind that there is a wide range of subsidiary industries whose workers would not be classed under the head of " agriculture," though in supplying agricultural implements and machinery, fertilisers, feeding stuffs and other requisites, they are, from the industrial standpoint, no less concerned in agriculture, and are no less living on agriculture, than the farm occupiers and the permanent labourers themselves. If, also, we add to those who are thus engaged, directly or indirectly, in the production of agricultural necessaries the further classes concerned in the distribution of such necessaries when they have been produced, we shall see that the interests involved in the agricultural industry as a whole, and in the widest sense of the term, are practically illimitable in their extent.

\section{Agricultural Production.}

In the Board of Trade Report already mentioned the total " output " of the agricultural land of Great Britain in I 908 is stated to be $£ 150,800,000$. This figure, however, represents the value at market prices of products sold off the farms for consumption, the actual "sales" thus dealt with not including crops grown for the feeding of stock or for maintaining the fertility of the land. The total value, for example, of "farm crops" actually grown in 1908 is 
estimated at $£ \mathrm{I} 25,000,000$, whereas the total value of those sold, and representing the " output," is given as $£ 46,600,000$. Nor do the figures in the Report include either the produce of land occupied in smaller lots than one acre or the considerable but unknown amount of produce grown under glass.

Not only is this figure of $£$ r $50,800,000$ admittedly incomplete in itself, but there is difficulty in comparing it with the " output " of other industries reported on under the Census of Production Act, (I) because " estimated value of the materials used" is not deducted in the case of the agricultural output, though it is in that of the other industries, and (2) because the figures given for the agricultural output are for Great Britain only, whereas those for the other industries are for the United Kingdom.

Subject to these reservations, I give the following table, showing the gross output (in I908) of agriculture in Great Britain as compared with the net output (in 1907) in Great Britain and Ireland of a few other typical industries :-

\begin{tabular}{|c|c|c|}
\hline Agricultur & & $I_{50} \stackrel{t}{800,000}$ \\
\hline Mining and quarrying & - & I $8,759,000$ \\
\hline Textile trades & .. & $96,063,000$ \\
\hline Engineering, etc. . & $\because$ & $84,214,000$ \\
\hline Building and contractin & g trades & $42,954,000$ \\
\hline Clothing trades & .. & $39,710,000$ \\
\hline Iron and steel trades & & $39,578,000$ \\
\hline Chemical and allied trac & & $20,879,000$ \\
\hline ides other than & engineering & $20,287,000$ \\
\hline Shipbuilding & .. & $20,167,000$ \\
\hline
\end{tabular}

From the point of view, therefore, both of persons employed and value of output, and even without including subsidiary or dependent enterprises and occupations, agriculture must still be regarded as our leading industry.

\section{FOREIGN IMPORTS.}

This fact is the more remarkable when we take into account the enormous extent of our importations of food supplies. These included in the year IgII the following items:- 
ARTICLES.

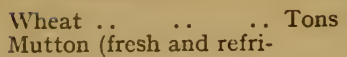

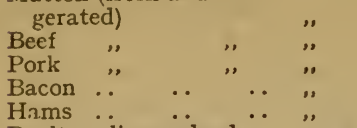

Quantities. $4,905,454$

266,873

$368, \mathbf{1} 22$

27,647

$2+3,437$

$47,74 \mathrm{I}$

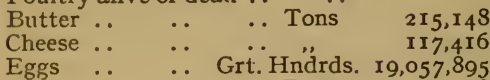

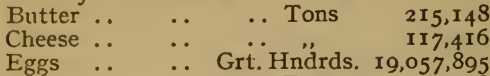

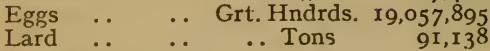

Margarine $\quad \ldots \quad \quad .$. Tons

Apples (raw) .. $\quad .$.

Grapes .. $\quad . \quad$.. ,

Pears ...

Onions ..

Potatoes

Tomatoes
47,220

166,631

29,289

$8,598,722$

163,120

68, I 18
35,069
Value. $£ 38,927,680$

$9,588,646$

$x \mathrm{x}, \mathrm{x} 36,223$

$\mathrm{I}, \mathrm{I} 2 \mathrm{20}, 764$

$\mathrm{I}_{4}, 463,4 \mathrm{I} 4$

2,927,610

918,197

24,602 , I I I

$7,139,942$

$7,965,609$

$4,25 I, 75^{8}$

$2,46 \mathrm{I}, 32.5$

$2,232,992$

785,326

544,706

I, 222, 278

$\mathrm{x}, 307,446$

I, 125,252

The sum total of the figures in the last column is £I32,72I,279.

It will be seen that the largest item in the table is in respect to imports of wheat, the value of which amounted to, in round figures, $£ 39,000,000$, and that the next largest item is for butter, which was imported to the extent of $£ 24,600,000$. One must, however, remember that when the British farmer can get a good market in some urban centre for his new milk, it pays him better to dispose of it in that form than to attempt to compete with the foreigner in turning his cream into butter. It should further be remembered (I) that many of the commodities imported could not be produced at all in this country; (2) that others come to us at a time when, owing to the difference in seasons, our own supplies are not yet ready ; (3) that we could not meet the whole of our requirements in regard even to necessaries within the range of our climatic or other conditions; and (4) that in the increase of our output in commodities which we could, and should, produce on a large scale for ourselves a great work can be done by agricultural organisation.

Still more important is the fact that, although wheat production has greatly declined in the United Kingdom, increased attention is being paid in this country-under the 
" transition in agriculture"is materially owing to this cause that the agricultural industry has maintained the aforesaid standard, notwithstanding the substantial nature of the foreign imports.

This last-mentioned fact is deserving of detailed consideration.

\section{FARM CROPS.}

In the Board of Agriculture Report on the agricultural output, the gross value, at market prices, of the wheat produced in Great Britain in 1908 is given as $f_{10,370,000 .}$ The value of wheat imported into the United Kingdom in the same year was $£ 38,296,000$. Here, therefore, the foreigner had the advantage. But in regard to the two other chief corn crops we get the following values :-

BARLEY.

E

Output in Great Britain ‥ $\quad$ 9, I 77,000

Imported into U.K. . . . . $6, \mathrm{II}_{4}, 000$

Excess of output over imports .. $\overline{3,063,000}$
OATS.

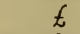

$13,264,000$

$4,163,000$

9, IOI, 000

The British farmer, again, held his own in respect to the following crops, the chief among those that are used for fodder :-

Crops.

Turnips and swedes $\quad . \quad \quad \ldots \quad 23,768,000$

$\begin{array}{lllll}\text { Mangolds } & . . & \ldots & \ldots & 8,995,000\end{array}$

Clover and "seeds" hay $\quad \ldots \quad 3,507,000$

Meadow hay $\quad . . \quad \ldots \quad \quad \ldots \quad 6,2 I_{3}, 000$

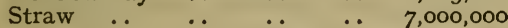

VALUE.

$t$

$23,768,000$

$7,196,000$

I $2,712,000$

$19,106,000$

I $2,660,000$

\section{MARKet Garden Produce.}

Then we have the fact that in recent years there has been a great increase in the growing of market garden produce on both a large and a small scale.

The growing of vegetables, partly for fodder but mainly for human consumption, is a development of modern farming of which due account must needs be taken, though there is a lack of exact figures as to quantities and values 
owing to the absence of information concerning small plots of land of less than one acre, not included in the recognised "farming area" of the country. The number of such plots was given in the Allotments Return, published in 1895 , as 579,133 . Whatever the present number, it is certain that the vegetables grown on them, for sale as well as for consumption by the occupiers and their families, would, in the aggregate, greatly increase the official "output" figures. Taking, however, the figures as recorded for the year Ig08 we get the following items :-

Crops.

Potatoes.

$\begin{array}{llllr}\text { Cabbages } & \ldots & \ldots & \ldots & 3,918,000 \\ & & & & \\ & & & \end{array}$

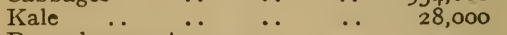

Brussels sprouts $\quad \ldots \quad$.. $\quad$ I0,000

Broccoli and cauliflowers $\quad \ldots \quad 28,000$

$\begin{array}{lllll}\text { Carrots .. } & \ldots & \ldots & \ldots & \text { I29,000 }\end{array}$

Onions .. $\quad \ldots \quad \ldots \quad \ldots \quad 18,000$

$\begin{array}{lllll}\text { Rhubarb.. } & \ldots & \ldots & \ldots & 18,000\end{array}$

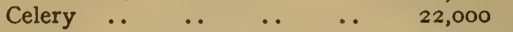

VALUE.

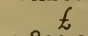

$9,892,000$

760,000 26,000 56,000 80,000 I 59,000 I06,000 I 81,000 72,000

The values of a large number of other crops includeMustard, $£$ I07,000 ; asparagus, $£ 42,000$; parsnips, $£ 36,000$; lettuce, $£ 34,500$; sea kale, $£ 32,000$, and beetroot, $£ 26,000$. Considerable areas are devoted to the growth of crops for seeds. The gross value, for instance, of 5,400 tons of clover, mangold, turnip, swede, vetches and trefoil seed produced on 13,700 acres in 1908 was $£ 132,000$. There is, again, a large number of crops not of sufficient individual importance for separate tabulation. Still another series consists of crops indefinitely described as flowers, grass, green crops, salad crops, root crops, herbs, bulbs, etc. The amount of land devoted to these two groups of crops in 1908 was 30,000 acres, and the gross value of the produce from them was estimated at $£ 352,000$.

FLOWERS.

The cultivation of flowers for sale on the market has likewise undergone considerable expansion of late years. "In many parts of England," says the Board of Agriculture 
Report, " its importance as a means of exploiting land which would be less profitably devoted to ordinary farm crops is well recognised." The total area in Great Britain thus used for the cultivation of flowers and shrubs is estimated at 4,000 acres, and the gross value of the production is put at £I2I,000.

\section{FRUIT.}

From the same source we learn that the extent of land returned in 1908 as occupied by orchards was 250,297 acres, of which 27,433 acres bore small fruit as well as tree fruit. The area devoted to small fruit alone was 57,447 acres, so that altogether the acreage of small fruit, on holdings exceeding one acre, was 84,880 ; but the total would be substantially increased if plots of less than one acre on which small fruit is grown for sale were added.

Returns for 1908, when the fruit crops were considerably below the average, give the following values :-

\begin{tabular}{|c|c|c|c|c|c|}
\hline \multirow{2}{*}{\multicolumn{4}{|c|}{ Small Fruit :- }} & \multirow{2}{*}{$£_{1,036,000}$} & \multirow{2}{*}{$£$} \\
\hline & & & & & \\
\hline Raspberries & & .. & 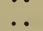 & 309,000 & \\
\hline Black currants & & .. & .. & 84,000 & \\
\hline Red and white & currant & & .. & 69,000 & \\
\hline Gooseberries & & & .. & 208,000 & \\
\hline Other kinds (in & cludir & mixed & & 252,000 & \\
\hline Total sn & tall frui & & . & ․ & $1,95^{8,000}$ \\
\hline ORCHARD FRUIT & :- & & & & \\
\hline Apples $\ldots$ & . & . & .. & $I, 490,000$ & \\
\hline Pears & . & . & .. & 90,000 & \\
\hline Cherries .. & . & . & .. & 194,000 & \\
\hline Plums $\quad .$. & & & $\cdots$ & 357,000 & \\
\hline Other kinds (in & cluding & nuts : & and & & \\
\hline mixed) & .. & $\cdots$ & .. & 406,000 & \\
\hline Total or & chard $\mathrm{f}$ & ruit & $\cdots$ & ・. & $2,537,000$ \\
\hline Total al & fruit & .. & - & .. & 4,495 \\
\hline
\end{tabular}

Cider ANd PeRry.

In the values of apples and pears, given in the foregoing list, are included those of fruit used for making cider, perry and cider-perry. The quantities of these beverages produced on over-one-acre farms in the chief cider-making counties in 
I908, the total values, and the values of what was sold (that is to say the commercial " output," the remainder being used for domestic consumption), may be shown thus :-

Beverage. Produced. Value.

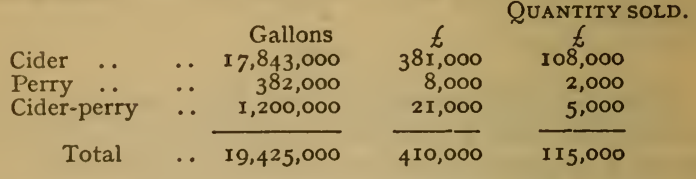

In addition to the production on farms, there is a considerable output from cider and perry factories, estimated for I907 at 2,708,000 gallons, of a value of $£$ I53,000, and in-

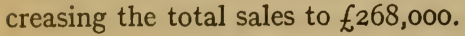

CROPS UNDER GLASS.

While the Report states that " the great extension which has in recent years taken place in the cultivation of crops under glass has, of course, considerably increased the total output of the land," it confesses that complete statistics in respect thereto are not at present available. In regard, however, to the one item of tomatoes, the value of the crops included in 45 returns from 22 counties is put at $£ 43,000$. From the returns giving the extent of glass under which the crops are grown, it appears that on 20 acres an average of over 600 tons of tomatoes was cut, being an average yield of over 30 tons, valued at $£ 830$, per acre.

Next to tomatoes, cucumbers, grapes and chrysanthemums are most largely grown under glass. Other crops include strawberries, peaches, lettuces, radishes, beans, rhubarb and narcissi.

The returns in which the area of the glass and the value of the produce of all crops grown thereunder were shown give a total of I55 acres, with an output of $£$ I50,000, or $£ 968$ per acre.

\section{ANimals.}

In the department of live stock, the number and the value 
of animals sold off the farms of Great Britain during I908-9, were as follows :-

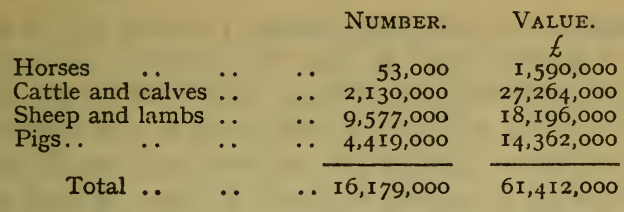

\section{Wool.}

The total value of the wool produced in Great Britain in I 908 is estimated at, in round figures, $£ 3,100,000$.

\section{DAIRY PRODUCE.}

The quantities and values of dairy products sold by the farmers of Great Britain in 1908 are calculated as under :-

Quantity.

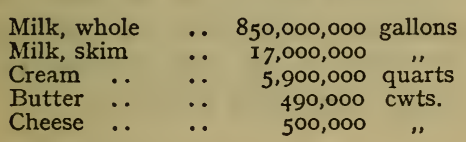

Total value.. $\quad$.. $\quad . . \quad$..

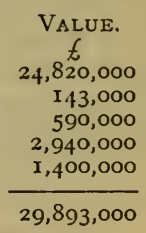

Here one sees by actual figures how the British farmer looks to gain, in regard to dairy produce, from the sale of whole milk, in regard to which foreign competition is a negligible quantity, rather than from butter and cheese, where the foreigner has a much better chance. It will be observed that although we imported in IgII butter to the value of $£ 24,600,000$, British farmers sold, in I908, whole milk of a still greater value, while as against their own $850,000,000$ gallons in 1908 , the total quantity of fresh milk imported into the United Kingdom in that year was only Io,460 gallons, though in I9II the imports of fresh milk from France and Holland amounted to 120,000 gallons. 


\section{POULTRY AND EgGs.}

Inasmuch as a very large quantity indeed, in the aggregate, of poultry must be kept by cottagers and town or suburban residents not coming within the scope of the official returns, statistics relating only to the number on farms of over an acre in size can give no adequate idea of the sum total of poultry in Great Britain. It may be, as the Report suggests, that the greater part of the less-thanone-acre production thus excluded is consumed by the poultry-keepers themselves; but one of the essential objects of the co-operative poultry societies of to-day is to enable "small " as well as " large " poultry-keepers to market their surplus stocks to advantage.

Still, taking these inadequate official returns as they stand, one learns from them that the total value of the output of eggs and poultry from the over-one-acre holdings in Great Britain is estimated at about $£ 5,000,000$. To this figure must be added the value of the considerable supplies raised in Ireland. The home production, however, is still so far short of the demand that, as reference to the table already given will show, the value of the eggs imported into the United Kingdom in IgII was nearly $£ 8,000,000$.

\section{The Situation in Brief.}

The final outcome of a comparison between food imports and home production is to show that, great as are the former in magnitude, they are still materially less than the food supplies we raise for ourselves.

This fact was well shown by Mr. R. H. Rew, C.B., one of the assistant secretaries of the Board of Agriculture, in a paper on "The Nation's Food Supply," which he read at the I9I2 meeting of the British Association. Dividing home production from imports, deducting exports, and omitting sugar, tea, coffee and cocoa, for which there is no corresponding home production, Mr. Rew gave the following 
figures in regard to items which may fairly be regarded as comparable :-

Produce.

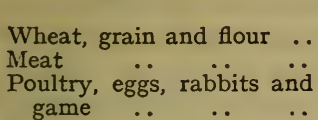

\begin{tabular}{|c|c|c|c|c|}
\hline (ish & & & & \\
\hline & & .. & $9,000,000$ & $3,000,000$ \\
\hline Dawy & & & $42,000,000$ & $35,000,000$ \\
\hline Fruit & & & $6,000,000$ & $16,000,000$ \\
\hline Vegetables & & • & $20,000,000$ & $4,000,000$ \\
\hline Total & & & $E^{1} 80,000,000$ & $£ 167,000,000$ \\
\hline
\end{tabular}

If the total value of the imports is deducted from that of the home production, there will be found a balance of $£ \mp 3,000,000$ in favour of the latter; but this balance would be substantially increased if there could be added to it the value of the home production on small holdings and gardens not included in the official returns.

While, therefore, the agricultural position in Great Britain to-day may still be discouraging for the gentleman farmer of the olden type, who finds it so difficult to compete with the wheat imports from other countries, the facts and figures here presented show that the situation still affords plenty of encouragement to working farmers, market gardeners, dairy farmers, live-stock breeders, and small holders producing other crops or other alternatives to wheat-growing.

As against restriction of opportunities in some directions there has, in fact, been a widening out of opportunities in others ; though the later developments have applied mainly to "smaller" types of producers, and that, too, under conditions which render especially desirable and necessary an ever-increasing resort in Great Britain, as in other countries, to agricultural organisation.

\section{NEED FOR ORganisation.}

Most of the fundamental reasons for agricultural organisation which apply to the countries of the world in general, 
apply equally well to this country; but there is here this further consideration, - that in improving their own agricultural position, and in extending the volume of their own output, many of these other countries-including most of those on the continent of Europe, together with Canada, Australia, South Africa and Argentina-are looking to British markets as a means of disposing of their own surplus production.

Thus the more that agricultural organisation spreads abroad, the more will foreign competition increase on our own markets, and the greater will be the need for the British farmer to defend his own interests by himself also resorting to the same principle.

This is not the place in which to discuss disputed questions in regard to protective duties. It might, nevertheless, be pointed out that, even assuming such duties should be imposed in the interests of British farmers, they might fail in their purpose unless, with the help of agricultural organisation, the British farmer secured, as far as possible, the same economic advantages as the foreigner had gained by that means, since the savings effected by the foreigner, together with his better system of marketing, might still enable him to compete successfully with our own growers when these were producing at greater cost and marketing under less satisfactory conditions.

The phases of agricultural organisation more especially called for in Great Britain are: (I) economic production ; (2) combination for transport ; and (3) scientific marketing.

\section{Production.}

Apart from that question of credit which, as I have shown, formed the initial stage of the movement in Germany in the middle of the nineteenth century, the beginnings of agricultural organisation in general are to be found in combination for the purchase of agricultural necessaries with a view both to economy in production and to a guarantee of good qualities. 
Such need has more especially been found in regard to the purchase of artificial fertilisers.

The magnitude of the manufacturing industry to which the use of these now indispensable requisites in farming has led in Great Britain is suggested by the following figures for 1907 , taken from the Board of Agriculture Report on the Agricultural Output :-

\begin{tabular}{|c|c|c|c|c|}
\hline & & . & $\begin{array}{l}\text { Tons. } \\
203,000\end{array}$ & $\underset{278,000}{t}$ \\
\hline sphates & .. & . & 603,000 & $1,320,000$ \\
\hline Sulphate of ammonia & & . & 260,000 & $2,823,000$ \\
\hline Other manure & .. & .. & 492,000 & $2,250,000$ \\
\hline Total & .. & & $55^{8}$ & 0 \\
\hline
\end{tabular}

Imports of fertilisers into the United Kingdom in the same year amounted to a total of 296,000 tons, valued at $£ I, 703,000$. Deducting net exports from the home production, and omitting the figures for Ireland, the Board of Agriculture Report calculates that the value of the artificial fertilisers available for use on farms in Great Britain in 1907 was between $£ 2,900,000$ and $£ 3,900,000$.

The world's consumption of nitrate of soda in IgII is shown by Messrs. W. Montgomery \& Co., in a report on the fertiliser industry in that year, to have been $2,394,000$ tons, as compared with $2,24 \mathrm{I}, 000$ in I9IO, an increase of $4.82 \mathrm{per}$ cent. An analysis of the European consumption in I9II as compared with IgIo gives the following figures:-

\begin{tabular}{|c|c|c|c|c|}
\hline COUNTRY. & I9II. & rgro. & INCREASE. & DECREASE \\
\hline 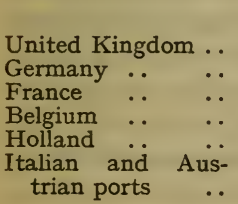 & $\begin{array}{r}\text { Tons. } \\
\text { I } 32,000 \\
724,000 \\
332,000 \\
294,000 \\
141,000 \\
56,000\end{array}$ & $\begin{array}{r}\text { Tons. } \\
\text { I } 20,000 \\
751,000 \\
320,000 \\
274,000 \\
131,000 \\
50,000\end{array}$ & $\begin{array}{c}\text { Per cent. } \\
\text { I0 } \\
-3 \\
3 \frac{3}{4} \\
7 \frac{1}{4} \\
7 \frac{1}{2} \\
\text { I2 }\end{array}$ & $\begin{array}{c}\text { Per cent. } \\
\text { - } \\
\text { - }\end{array}$ \\
\hline
\end{tabular}

Manufactured feeding stuffs available for consumption in Great Britain in I907, as given in the Board of Agriculture Report, are valued as follows :-

A.O. 


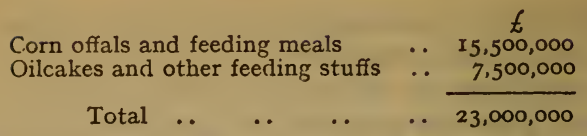

These figures sufficiently confirm what has already been said as to the results of advanced scientific methods of agriculture in leading to the creation of great industrial and commercial interests whose main concern in the agriculture on which they have flourished has naturally been the particular extent to which the supply of its needs would tend to their own benefit.

Taking further into account what British farmers must pay in the course of a year for seeds, implements, machinery and other necessaries, it will be found obviously to their advantage, as an ordinary business proposition, to resort to joint action in order (I) to buy wholesale instead of retail ; (2) to obtain effective guarantees of good quality; and (3) to protect their own interests generally against powerful combinations on the part of manufacturers or middlemen traders.

All these things have a direct bearing on cost of production, and the same consideration is involved in the setting up of co-operative dairies, cheese factories, etc.

\section{TRANSPORT.}

In Great Britain, where agricultural production in general is on a smaller scale, and much of the home produce goes direct from the place of origin to the place of consumption, there is not the same opportunity for making up train-load lots as in countries which not only produce on a very large scale but regularly make up such lots for shipment to this country; though it must be remembered that, while the foreign produce received here in these large quantities thus secures the lowest rates for transport, the material consideration is, not the amount they have paid for the journey from the port of arrival to (say) London (which amount forms part only of a through rate, and is influenced by bulk of consignment, packing, etc.), but the sum total of the charges for 
their transport from point of despatch, the said total requiring to be covered by the market receipts before there can be any question of profit on the sale.

No one suggests that the rates for the transport of foreign produce should be raised in order, as it were, to "protect" the British farmer against the foreigner ; but there have been suggestions that the rates charged to the British farmer should be lowered.

To this it has been replied (I) that the railway companies cannot afford to charge the same rates for small consignments of produce, collected from wayside stations, inadequately packed, and involving a proportionately higher cost for transport, as they charge for large consignments carried under the most economical conditions from the point of view of working expenses; (2) that these differences in charges do not constitute an undue preference ; and (3) that the railway companies already have on their books lower rates by which British producers can send if only they will, where necessary, combine their consignments so as to make up the specified lots in respect to which these lower rates are available.

Combination brought about through agricultural organisation should allow of greater advantage being taken of these existing opportunities, and also-when the facilities thus already available have been exhausted-place the associated producers in a better position to offer representations to the railway companies in regard to other matters on which they may desire to make their views known.

There is the more need for such combination for transport since in dealing with markets where competition-whether foreign or home-often reduces the chances of profit to a minimum, it may be of no less importance to secure the lowest possible railway rates than it is to effect all practicable economies in production.

\section{Scientific Marketing.}

Regarding agriculture in the light of a business enterprise, much-though not everything-must needs depend 
on the prices obtained for the commodities sold on the market.

In the making up of the final accounts, undue cost either of production or of transport may nullify the profits that would otherwise have been obtained from market returns in themselves fair and reasonable; but assuming that, by means of combination, the growers have kept (I) cost of production and (2) cost of transport to a minimum, they may still have unsatisfactory returns if the market prices should be inadequate, or if there should be too many middlemen, each wanting his profit or commission. Left to their own resources, and acting as individuals, the producers may fail to grow the qualities suited to particular markets ; they may err on the side of growing too many varieties of a certain commodity, and they may show such a deficiency of knowledge in picking, grading and packing that, notwithstanding their greater nearness to home markets, they will fail to overcome the competition thereon of foreigners who, thanks to effective organisation, send their commodities to us in a way more likely to secure the favour of purchasers.

These considerations especially apply to the fruit and market gardening industry, which, owing to the perishable nature of the commodities concerned, are in greater need of effective organisation than any other branch of agriculture or horticulture.

Under established conditions growers throughout the greater part of England generally attempt to solve the problem of marketing by consigning to one of three markets -London, Manchester or Liverpool ; and, as the result of this practice, a glut may be brought about on any one of these markets, with the inevitable result of unsatisfactory prices, when but few supplies are going direct from the growers to numerous smaller markets the wants of which are catered for by middlemen dealers, who thus obtain profits which ought, rightly, to come into the pockets of the producers.

Scientific marketing thus means, in the first instance, improved methods of distribution. 


\section{MORE MARKeTS WANTED.}

Writing on the subject of markets in its issue of March 3oth, I9I2, the Flower, Fruit and Vegetable Trades Journal said :-

With the increased acreage under cultivation, the fruit industry demands more and better markets in London and the provinces. It is absurd that in London alone there should be so few wholesale markets. Those existing are inadequate, shut in, and overcrowded, the worst case being that of Covent Garden Market. The time has come when there should be founded open markets in the inner circle of the London suburbs. Markets in such places would prove a great boon to suburban dealers and greengrocers, and also to those growers who at present have to send their vehicles right into the crowded heart of London. . . . Many more markets might well be established in the great industrial centres in the north.

\section{MARKETING METHODS.}

Whether, too, there be any glut on the leading markets or no, and whatever the market to which produce is consigned, there is the consideration that the individual grower is, in any case, generally at the mercy of the commission agent with whom he deals.

Our marketing methods were subjected to very severe criticism at a conference of fruit-growers in the Commonwealth of Australia held at Hobart, Tasmania, in October, IgIr. One speaker, Mr. W. D. Peacock, whose firm, he said, had exported in a year 196,000 cases of their own, apart from consignments on commission, gave an account of his experiences in England, saying, among other things :-

The trouble in London was that there were so many people receiving fruit, and so many putting it on the market at the same time. There was no co-operation in any shape or form. With regard to Covent Garden itself, it was a commercial disgrace. There was really no system there, and it was an absolute impossibility for any man to follow his fruit through there and know exactly what he made. There was no system and many of the brokers kept no books. . . . All through he had not the slightest doubt he was being got at, on Covent Garden, and he had no doubt he was being got at now.

In discussing marketing methods in general, and in pointing more especially to the want of an outlet of such a nature 
as to ensure that honest and best returns will be received for the produce sent to market, an organiser of the Agricultural Organisation Society reports :-

I know instances of men posing as commission agents who are not on a level from the point of view of honesty with the ordinary hawker, though to judge by their beautifully-got-up letter-paper one would really think they were men of great importance and thoroughly to be relied upon. In one case that I know of a grower sent $£ 40$ worth of goods to a man of this type, and has not yet received a single penny. Another salesman had a ton of fruit sent to him, and after a good deal of writing the grower obtained $£ 4$, though the current market price was $£$ I8. These are not the worst cases I know of ; I could give scores of others.

If, instead of consigning to distant markets, the grower disposes of his produce to a higgler who comes to his door, to an agent who buys the crop as it stands, or to a dealer in the market of the neighbouring town, he may still receive less than he might obtain through an agricultural co-operative society specially organised for the purposes of sale, while the said society would save him the time he would otherwise have to devote either to going to market or in hawking round his produce in his own neighbourhood, thus enabling him to devote more attention to his proper work of production.

\section{Utilisation OF SURPLUS Stocks.}

In addition to more markets and improved marketing methods, there is a great need in England for some organised system under which, in times of over-production, sur lus stocks can be kept back from markets already over-supplied and on which they would only lead to a lowering of prices all round, and be converted, instead, into bottled fruits, dried vegetables or other saleable commodities on which, apart from the consideration just suggested, additional profits might be made. The same course should be adopted in regard to lower grades of produce which would equally prejudice the market prices but might well be used for these other useful and remunerative purposes. 


\section{The "Back to the Land" Movement.}

Various schemes in regard to the conditions under which land should be held by cultivators in this country are now under discussion, and the problem of tenancy (whether under private or public authorities) versus peasant proprietary is engaging considerable attention.

Here, however, we are concerned only in the fact that, whether the producers settled, or about to settle, on the land are owners or only tenants of their holdings, it will be equally necessary that they should be enabled to raise, consign and market their produce under the most favourable conditions; and, speaking generally, it will be impossible for them to do this without the help of co-operation.

Much has been heard about settling more people on the land through the action of the State. If the people so settled propose to do no more than raise supplies for their own consumption they may do so with complete success. If they propose to raise supplies for sale, and if, in doing this, they remain individual units, each paying an unduly high price for his necessaries, consigning otherwise than at the lowest railway rates, and selling under such conditions that the chances will be all against him, then the result of the State experiment may be little less than a complete failure.

\section{Shortcomings of State Aid.}

In addition to encouraging more people to settle on the land the State has at different times given much active support to agricultural research with a view to increasing and improving production; but increased production for sale is not of much use without adequate opportunities for successful distribution of the commodities produced, and here the action of the State has stopped short.

It may well be said that marketing is not the work of the State, and that there would be difficulties in the way of the State undertaking it. But the shortcomings of State action in this respect can well be made good by the efforts of an independent organising body, able to act without the dis- 
advantages that would needs arise when the State sought to deal with questions as to the business relations between producers, dealers and consumers.

Agricultural organisation is thus not superseding, but supplementing, State action. It is simply the logical, though indispensable, sequel thereto.

\section{RURAL HoUSING.}

Another subject which has attracted considerable attention of late is that of rural housing.

There are not sufficient cottages in the country districts, and one of the principal reasons why more are not built is that labourers cannot afford to pay the rents which would have to be paid to ensure a reasonable return on construction -and especially on the construction of the superior type of cottages that may alone be built under what are declared to be unduly exacting rural bye-laws.

The alternative would seem to rest between $(x)$ an alteration in the bye-laws, so as to allow of cheaper cottages: and (2) the payment of higher wages which would permit, in turn, of higher rents. The adoption of the former remedy may be hoped for in course of time; that of the latter is objected to by the farmers on the ground that they cannot afford to pay higher wages.

If, however, by means of agricultural co-operation, the farmers are enabled to effect material savings in production and on transport, and, at the same time, secure a better return from sales, they should then be well able to give the higher wages which would enable their labourers to pay reasonable rents for decent cottages.

\section{CREdit.}

Many, if not most, of the arguments advanced in favour of the fundamental principles of agricultural credit, as adopted in Germany, Denmark and other foreign countries, apply with equal force to Great Britain, and they do so with this additional consideration as regards ourselves- that here the agriculturist's opportunity of securing credit through the 
local joint-stock bank is decreasing owing to the tendency for such local banks to be acquired by and amalgamated with great banking concerns in London which operate them more from the point of view of London City, or international, finance, and have a less intimate knowledge of, and a leśs sympathetic feeling towards, the farmer and his needs than the private bankers whose place they are taking.

In Great Britain, therefore, further facilities are wanted, not alone for small holders, but for large sections of farmers as well; and once more we find good reason why Great Britain, no less than the other countries of the world, should have an efficient scheme of agricultural organisation. 


\section{CHAP'TER IV.}

\section{THE MOVEMENT IN IRELAND.}

IT was in Ireland that, thanks mainly to the practical patriotism and untiring zeal and devotion of Sir Horace Plunkett, the principle of agricultural co-operation was first established in the United Kingdom.

Ireland had suffered no less than other countries from the various conditions affecting agriculture in Europe generally of which I have already spoken, besides having difficulties and disadvantages essentially her own; and, struck by the state of things he saw around him in Ireland on his return from a prolonged residence in the United States, Sir Horace (then Mr.) Plunkett conceived the idea, in I889, of taking action with a view to bringing about an economic improvement in Irish conditions on the lines of combined action.

At that time agricultural co-operation was, of course, far less developed in European countries than is the case to-day, and the only precedent which Sir Horace was then able to find for the New Movement he proposed to start was the one furnished by the Co-operative Movement in England, which, however, originally founded by the Rochdale Pioneers, was mainly concerned in the creation of consumers' societies for the supply of household or other requisites. So, in company with Lord Monteagle and Mr. R. A. Anderson, his first two associates in the campaign on which he started, Sir Horace became a regular attendant at the congresses of the Cooperative Union in England and a no less persistent seeker for information at the headquarters of the Union in Manchester. From such champions of co-operation as Vansittart Neale, Tom Hughes and George Holyoake much sympathy and encouragement were received. An Irish section was set up by the Co-operative Union which, also, contributed to 
the initial expenses of the propaganda, and from 1889 to 1894 the "New Movement " in Ireland was little more than a reproduction of what was then an old movement in England.

Experience soon convinced Sir Horace that the regeneration of Ireland's economic condition was not to be brought about by the establishment of co-operative stores alone, and that advancement of the agricultural interests on which that country depended in so material a degree should be sought chiefly by an adoption of the principle of co-operation in production, more especially in regard to those butter supplies to the provision of which the agricultural and climatic conditions of Ireland were especially adapted. In this way there was evolved by Sir Horace Plunkett a scheme for the creation of co-operative dairies in Ireland some time before he learned that such dairies were then already an established institution in Denmark.

In 1893 the English Co-operative Wholesale Society began to start creameries of its own in Ireland. "In the profits and management of these concerns," as Sir Horace said, when addressing the Economic Society of Newcastle-on-Tyne on October 27th, I898, " farmers had no share. This was so diametrically opposed to the principles of co-operation, as we understood them, that the two movements became independent of each other."

In April, I894, the movement for agricultural co-operation had so far expanded-although the number of local dairy societies was still comparatively small-that a new organisation, under the title of the Irish Agricultural Organisation Society, and looked upon as " the analogue of the Co-operative Union in England," was formed to carry on a work of promotion and supervision which had become, as Sir Horace told, " too onerous and costly for a few individuals to bear." Men of all creeds and parties joined it, and undertook to supply funds for what was regarded as a five years' experiment, though one which, as the result proved, was to be so successful that the Society became established on a permanent basis. 
Apart from the initial idea in regard to co-operative stores, agricultural co-operation in Ireland had thus resolved itself at the outset into an application of the co-operative principle to the dairying industry. On this point Sir Horace further said, in his address to the Newcastle-on-Tyne Economic Society :-

We selected for our first essay the dairying districts of the South for several reasons. If we had begun in the more advanced parts of Ireland, while failure would have been fatal, success would not have carried conviction as to the applicability of our scheme elsewhere. Moreover, the dairying industry was just then undergoing a complete revolution. The market was demanding, in butter as in other commodities, large regular consignments of uniform quality. The separator and other newly-invented machinery were required to fulfil these conditions. The factory system was superseding home production, and the only way in which farmers could avail themselves of the advantages of the new appliances which science had invented, but which were too costly for individual ownership, was by combining together to erect central creameries, to own and work their machinery themselves at their own risk and for their own profit. No better advice could just then be given to the Irish farmers than that they should follow where the Danish farmers had led.

The difficulties of the task, however, were formidable in the extreme. It was far from sufficient to convince the farmers of the economic advantages of co-operative action. The real difficulty began with an attempt to clear their minds, not only of suspicions of sinister motives on the part of their advisers, but also of their innate distrust both of one another and even of themselves, and the chances of success appeared to be entirely against the pioneers of the movement. On this point Sir Horace Plunkett observed in his Newcastle address :-

The superior persons who criticised our first endeavours at organising dairy farmers told us that the Irish can conspire but cannot combine; the voluntary association for humdrum business purposes, devoid of some religious or political incentive, was alien to the Celtic temperament, and that we should wear ourselves out crying in the wilderness. Economists assured us that, even if we ever succeeded in getting farmers to embark in the enterprise, financial disaster would be the inevitable result of the insane attempt to substitute, in a highly technical 
manufacture, democratic management for one-man control. We admitted the force of these objections, but having an unbounded faith in the latent capacities of our countrymen, and knowing that success in this first application to a great national industry of organised self-help would open up prospects of amelioration in every department of Irish agricultural life, we determined to persevere until practical demonstration had proved us right or wrong.

Fifty meetings were attended by Sir Horace Plunkett before a single co-operative creamery had resulted therefrom, and nearly two years elapsed before a second was formed. For a long time he found the work of organising a wearisome business. On one occasion his audience consisted of the dispensary doctor, the village schoolmaster and the local sergeant of police. In some reminiscences of those days, published in the Irish Homestead, Mr. Anderson (who sometimes accompanied Sir Horace and sometimes held meetings of his own) wrote :-

It was hard and thankless work. There was the apathy of the people and the active opposition of the Press and the politicians. It would be hard to say now whether the abuse of the Conservative Cork Constitution or that of the Nationalist Eagle of Skibbereen was the louder. We were "killing the calves," we were "forcing the young women to emigrate," we were "destroying the industry." Mr. (Sir Horace) Plunkett was described as a "monster in human shape," and was adjured to "cease his hellish work." I was described as his " Man Friday" and as "Roughrider Anderson." Once when I thought I had planted a creamery within the precincts of the town of Rathkeale, my co-operative apple-cart was upset by a local solicitor, who, having elicited the fact that our movement recognised neither political nor religious differences, that the UnionistProtestant cow was as dear to us as her Nationalist-Catholic sister, gravely informed me that our programme would not suit Rathkeale. " Rathkeale," said he, pompously, " is a Nationalist town-Nationalist to the backbone-and every pound of butter made in this creamery must be made on Nationalist principles, or it shan't be made at all." This sentiment was applauded loudly, and the proceedings terminated.

On another occasion, mentioned by Sir Horace in his book, "Ireland in the New Century," a project for the conversion of a disused mill into a creamery had to be abandoned because the stream of water connected with the mill passed 
through a conduit lined with cement originally purchased from a person who occupied a farm from which another man had been evicted.

These early difficulties were overcome in course of time, and the new Society not only gained greater support, but was enabled to broaden out its sphere of operations and take up other important branches of agricultural co-operative action besides the co-operative dairies, and notably so in regard to the formation of agricultural credit societies, which were to render an invaluable service in providing Irish cultivators with a ready means of obtaining small sums for reproductive purposes without having to submit to the merciless exactions of the "gombeen man " or other local moneylender or trader.

Expansion of the Society's activities followed more especially on the proceedings of a committee of representative men of all parties which Sir Horace Plunkett was the means of constituting in the Parliamentary recess of 1895 (hence known as "The Recess Committee "), to consider what measures could best be adopted to promote the development of agriculture and industries in Ireland. The Committee caused inquiries to be made in Continental countries as to the methods by which Ireland's chief foreign rivals had been enabled to compete successfully with Irish producers even in their own markets, and a report on this subject was issued in August, I896, accompanied by a recommendation that there should be created a Department which, adequately endowed by the Treasury, and having a president directly responsible to Parliament, would administer State aid both to agriculture and to industries in Ireland upon certain specified principles. This recommendation was based on what had been found to be a policy adopted in certain Continental countries, while the proposal to amalgamate agriculture and industries under one Department was, as Sir Horace Plunkett explains in "Ireland in the New Century," " adopted largely on account of the opinion expressed by M. Tisserand, late Director-General of Agriculture in France, one of the highest authorities in Europe upon the administration of State aid to agriculture." 
A Department of Agriculture and Technical Instruction was duly created under the authority of an Act of Parliament passed in 1899, and the organisation of this Department included, in turn, a Council of Agriculture and two Boards of which one was concerned with agriculture and inland fisheries and the other with technical instruction. The Department relieved the Society of the cost of a considerable amount of the technical instruction it had previously given as a necessary adjunct to the work of organisation, to which it was now enabled completely to devote itself, and further agreed to defray the expenses of the I. A. O. S. in organising and supervising agricultural credit societies and subsequently also certain other kinds of societies. The grant in respect to these expenses for the year ending February 28th, I906, amounted to $£ 2,000$. There then came into force a new arrangement under which a grant was made to the general expenses of the Society on the basis of its income from voluntary sources, though the amount to be given was in no case to exceed $£ 3,700$. This arrangement lasted only until the end of 1908 , when the Department ceased to give a grant to the Society, which, however, still continues to receive a small grant from the Congested Districts Board, fixed in that year at $£ 35^{\circ}$ per annum. To the question of grants from the Development Fund to the Irish Agricultural Organisation Society reference will be made in the chapter that follows.

The present position of agricultural organisation in Ireland is shown approximately by the following table, taken from the report of the Irish Agricultural Organisation Society for the year ending June $30 t h$, IgII :-

\begin{tabular}{|c|c|c|c|c|c|}
\hline- & $\begin{array}{l}\text { Number } \\
\text { of } \\
\text { Societies. }\end{array}$ & $\begin{array}{l}\text { Member- } \\
\text { ship. }\end{array}$ & $\begin{array}{l}\text { Paid-up } \\
\text { Share } \\
\text { Capital. }\end{array}$ & $\begin{array}{c}\text { Loan } \\
\text { Capital. }\end{array}$ & Turnover. \\
\hline $\begin{array}{l}\text { Dairy societies } \\
\text { Auxiliary societies not } \\
\text { separately registered }\end{array}$ & $\begin{array}{l}312 \\
79\end{array}$ & 44,792 & $\underset{144,251}{£}$ & $\underset{120,35^{8}}{£}$ & $\begin{array}{c}£ \\
\mathbf{x}, 999,313 \\
\ldots\end{array}$ \\
\hline Agricultural societies & 165 & 16,743 & $6,68 \mathrm{I}$ & 36,545 & 124,720 \\
\hline Credit_societies & 237 & 19,190 & 一 & 55,884 & 55,855 \\
\hline
\end{tabular}




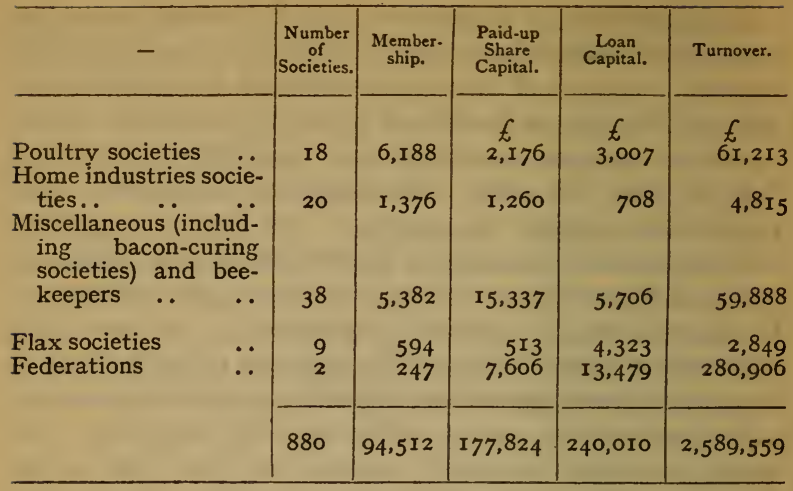

These figures, however, are not complete, inasmuch as particulars of membership were not obtainable from 2I creameries, I5 agricultural societies, 26 credit societies, I poultry society and 8 miscellaneous societies; and particulars of turnover were not obtainable from 18 creameries, 3 I agricultural societies, 57 credit societies, 5 poultry societies, I3 home industries societies, 4 flax societies, and 30 miscellaneous societies. The societies failing to furnish statistics include new societies, societies not carrying out any operations during the year, etc.

Since the Society started, the total turnover has been close on $£ 22,000,000$, included in this figure being $£ I 6,316,000$ on account of butter sales, and $£ 4 \mathrm{I} 2,000$, the total amount of loans granted by credit societies. On its work the Society has spent, altogether, over $£ 100,000$; but it is estimated that on the co-operative creameries alone the additional gain through the organisation is now $£ 400,000$ a year.

It will be seen that the leading position in regard to agricultural organisation in Ireland is still occupied by the co-operative creameries, the success of which, indeed, had led capitalists to set up proprietary creameries on their own account, so that already in 1907 the Irish Agricultural Organisation Society was able to report that the available 
ground for dairies had been almost completely covered by those of the one type or the other. ${ }^{1}$

Apart from the difficulties presented by what may be called the " human factor," the founders of the co-operative dairies had much trouble, more especially at first, in obtaining efficient managers. Then it was necessary to ensure the provision of adequate machinery, notably so in the case of pasteurising plant; much guidance was needed by some of the societies in regard to the keeping of the creamery accounts; strict cleanliness in handling the milk had to be vigorously insisted upon, and then when the creameries had been established, were working satisfactorily, and were producing large quantities of butter of the right quality, there came the further question of marketing on such lines as would ensure the best returns. With a view to overcoming this final difficulty, there was formed in 1892 an Irish Co-operative Agency Society, Ltd., to assist the co-operative creameries in marketing their butter.

The main feature in connection with the Irish co-operative agricultural societies for the supply of requirements is the extent to which they carry on their trade through the federated body known as the Irish Agricultural Wholesale Society, Ltd. One of the first achievements of this organisation was the breaking up of a "ring " of artificial manure manufacturers, with the result that prices were reduced by about 20 per cent. The " ring " was afterwards re-formed, and the Wholesale Society had a renewal of the same difficulties for a time; but these were eventually overcome. Trouble was, however, still experienced in regard to the implement manufacturers. In the sale of seeds of guaranteed purity at the lowest prices the Agricultural Wholesale Society has rendered good service to the Irish farmers. The greater part of co-operative trade in agricultural requirements in Ireland is, in fact, done through the Society, which has depots in Dublin, Belfast, Sligo, Foynes, Thurles,

1 The position in Ireland in this respect compares strongly with that in England, where the principle of co-operative dairies has undergone but comparatively little development because of the greater advantage derived by the farmer from sending his milk to the towns.

A.O. 
Cahirciveen, Cork and Waterford, and agents in the principal cities in Great Britain for the marketing of eggs, honey, etc. It also has a Banking Department which grants loans to trading societies experiencing difficulty in arranging for financial accommodation. The progress which has been made by the affiliated societies since 1906 is shown by the following table :-

\begin{tabular}{|c|c|c|c|c|c|c|}
\hline YEAR & .. & & Societies. & $\ldots$ & .. & SALES. \\
\hline 906 & $\cdots$ & . & 79 & $\cdots$ & & \\
\hline $\begin{array}{l}1907 \\
1908\end{array}$ & .. & & $\begin{array}{l}79 \\
91\end{array}$ & $\because$ & $\ddot{x}$ & 65,637 \\
\hline $\begin{array}{l}1909 \\
\end{array}$ & $\because$. & $\because$ & $\begin{array}{l}91 \\
105\end{array}$ & $\because$. & ". & $\begin{array}{r}13,35 \\
\text { ro } 4,326\end{array}$ \\
\hline & .. & & II8 & .. & & 123,508 \\
\hline & .. & . & 138 & .. & .. & r 32,929 \\
\hline
\end{tabular}

Credit societies play a still more important rôle, perhaps, in Irish agricultural organisation to-day than the creameries which preceded them in order of establishment. Ireland is better adapted than Great Britain for a widespread system of credit societies on the Raiffeisen model by reason of the fact that the peasantry there are on a more equal, and, financially, somewhat lower, footing than is the case with our own more diversified classes of agriculturists. Aided alike by advances from the Department of Agriculture and the Congested Districts Board and by generous treatment at the hands of the joint-stock banks, the credit societies have conferred very great advantages on the Irish peasantry, and not on them alone but, also, on the farmers in a higher social position who have, in turn, resorted to the same principle.

Action has also been taken in various directions to promote the co-operative sale of produce; though here there is a good deal of scope left in Ireland for further activity; the poultry and egg industry has been more successful when carried on by societies established for general trading purposes than by societies devoting themselves exclusively to this business, while the home industries societies have been an especially interesting development of organised effort in Ireland. 
While the table given on pp. $79-80$ is, notwithstanding its incompleteness, sufficiently suggestive of important economic benefits gained by the Irish people as the result of agricultural organisation, the moral results have been no less remarkable than the material results.

The Irish peasant has been not only saved by his credit societies from the merciless grip of the "gombeen man," but he has had instilled into his mind the principle of selfhelp through mutual help; he has been taught by the same credit societies the commercial value of a good name; he has learned to sink distrust and suspicion of his neighbour and adopt, instead, a spirit of comradeship towards him ; he can lay aside religious and political differences in order to discuss with those around him matters concerning their common welfare, and he is being subjected to important educational influences, either through the village libraries that are being set up, or through the instruction in improved methods he gets from organisers or other experts.

Then the social gatherings-dances, concerts, lectures and entertainments-organised by his co-operative agricultural societies, whether in the village halls specially provided by them or otherwise, are bringing fresh life into many an out-ofthe-way place where great need for it had hitherto existed.

So the New Movement has not only enabled the Irish peasantry to conduct their farming operations on improved lines but it has, from the point of view of what may be called its " human aspect," created in them a New Spirit which is, at the same time, making them better men and women, and giving them a New Outlook on life in general.

The experiences of societies affiliated to the Irish Agricultural Organisation Society and, also, the point of view from which their members regard the work that is being carried on, may be illustrated from the following typical examples, taken from a pamphlet issued in IgII under the title "Agricultural Co-operation in Ireland: A Plea for Justice by the I.A.O.S." :-

"It is impossible to estimate the amount of good done and the benefits conferred on the farmers of this district since the society 
was establiched by the I.A.O.S. The fields or the farms of members of the society are, as it were, miraculously changed in appearance in root, grain, and hay crops, and particularly in the pasture that follows. This arises solely from the use of pure seeds and highly classed artificial manures, these things having been obtained hitherto from publicans and grocers, who have no knowledge of seeds or manures; neither knowing how or where to purchase, they themselves the victims of low-classed artificial manure manufacturers and indiscriminate seed-vendors." -Jonesboro' Co-operative Agricultural Society, Co. Armagh.

"The co-operative movement has saved at least 30 per cent. to the farmers of this district in the purchase of artificial manures and other agricultural requirements."-Cam Co-operative Agricultural Society, Co. Roscommon.

"We made a profit on our trading during the first two years of $£ 220$, and during that time saved $£ 400$ to our neighbours in the price paid for cakes, coal, twine, manures and seeds, etc., besides giving them better quality than they were getting when paying higher prices."-Castledermot Co-operative Agricultural Society, Co. Kildare.

"The I.A.O.S., by teaching the farmers to combine for business purposes, has benefited the district to the extent of, approximately, $£ 700$ a year, not to speak of the social advantages, which are incalculable."-Tisara Co-operative Agricultural Society, Co. Roscommon.

"We can now purchase through our own society as much in the way of farm implements, seeds, manures, spraying material and general requirements, of a far superior quality, for $16 s$., as we could hitherto buy of inferior goods for 20 . In the sale of eggs we now receive $16 s$. for the same quantity which we used to sell for I2s."-Inniskeel Co-operative Agricultural Society, Co. Donegal.

" On the trade of $£ 20,000$ which we expect to do this year the members will be benefited to the extent of at least $£ 2,500$, and probably much more, as compared with the results that would be obtained by each member selling his farm produce and buying his requirements without the assistance which the society affords." -Achonry Co-operative Agricultural and Dairy Society, Co. Sligo.

"The members have benefited to the extent of 20 per cent. on their turnover, which is $£ 4,000$ per annum. This has come about by the raising of the price of milk by $I d$. per gallon in a few years, not to speak of the good done by showing the farmers of the district what they can achieve by co-operation in other industries." - Galteemore Co-operative Agricultural and Dairy Society, Co. Tipperary.

"During our thirteen years working .. . our suppliers have benefited to the extent of $f 19,000$ by adopting the cooperative creamery system of butter-making in preference to 
the old disorganised system of every man for himself."-Boyle Co-operative Agricultural and Dairy Society, Co. Roscommon.

"Education of various kinds has been spread, the value of union and fraternity has been demonstrated, the suitability of a good strain of milching cows and the proper method of feeding housing, etc., to provide a big milk supply, have been proved. The farmers' income has been increased by increasing his receipts per cow, whilst his expenses in marketing his produce have been diminished."-Glenmore Co-operative Dairy Society, Co. Kilkenny.

"The work of the I.A.O.S. in this district has been beneficial in so far that it has released its members from the grip of the auctioneer and professional moneylender who, as a rule, exact from their unfortunate customers from 15 to 20 per cent. interest, while the I.A.O.S. obliges these with ready cash at the modest charge of 5 per cent."-Cullamore Credit Society, Co. Tyrone.

"Since the introduction, in 1907 , of this form of credit by the I.A.O.S. into this district, it has effected a saving of at least $£^{I}, 000$ to the 200 farmers who comprise the society." - Culumbkille Credit Bank, Co. Longford.

"A farmer in the district got a loan, part of which ( $£ \mathrm{I}$ Ios.) he used in purchasing an old cow. To-day he owns seven or eight good cattle. To value at its true worth this little Bank one should interview the borrowers, who will explain, with natural pride, the help the I.A.O.S. has conferred upon them." Derrylohane Agricultural Bank, Co. Mayo.

"Immense benefit has resulted to the whole neighbourhood from the introduction of this lace industry in bringing in thousands of pounds, and enabling the people, who formerly were without means to do so, to improve their dwellings and the general conditions of life."-Ballysakeery Co-operative Home Industries Society, Co. Mayo.

"The I.A.O.S. has imbued the farmers with a spirit of selfconfidence, of pushfulness and enterprise, of order and method, as well individually as collectively." - Hollyford Co-operative Agricultural and Dairy Society, Co. Tipperary.

"Since the establishment of our society the farmers of the district are taking a keener and more business view of agricultural matters than formerly."-Devon Road Co-operative Creamery, Co. Limerick.

"The work of the County Committee has been made smooth and effective in our district, as the County Instructor found an organised body of farmers prepared and anxious to receive instruction."-Glenlough Agricultural Society, Co. Longford.

"In our committee we have Orangemen and the other extremists, who have learned to trust one another and work together for their common good. An improved feeling between all creeds and classes exists in this locality, attributable in a large 
degree to lessons they have learned by co-operation."-Whealt Co-operative and Dairy Society, Co. Fermanagh.

"Our beautiful co-operative hall stands proudly as an example of what can be attained by organised co-operative effort." Cushinstown Agricultural Bank, Co. Wexford.

"Besides teaching how to combine for their mutual financial betterment, the I.A.O.S. has had much to do with the visible social betterment of our rural community."-Enniscorthy Co-operative Agricultural Society, Co. Wexford.

"The work of the I.A.O.S. has created a new era of prosperity for the many farmers in this district." - Athlone Co-operative Poultry and Farm Produce Society, Co. Westmeath.

"Our society, which was organised by the I.A.O.S., has been of far greater benefit to the poor congest of this district than any Government Board has been for the last fifty years, although some of these Boards have spent thousands of pounds of public money here."-Templecrone Co-operative Society, Co. Donegal.

Still wider possibilities in the development of all this good work are being opened out by the establishment in Dublin of " The Plunkett House," in which the work is now carried on. It is the outcome of a movement set on foot in 1908 for presenting to Sir Horace Plunkett a testimonial in recognition of his services to agricultural organisation in Ireland, the substantial amount raised being, at the request of Sir Horace, devoted to the purchase of a large house which would serve as a headquarters for the study of rural sociology in addition to providing accommodation for the staff of the Irish Agricultural Organisation Society. A scheme for " A Country Life Institute: A suggested IrishAmerican Contribution to Rural Progress," was put forward in Igog by Sir Horace, in a Plunkett House pamphlet issued under this title. The aim of the Institute is therein stated to be :-

"To advance the well-being of the large and scattered agricultural population by bringing together information as to the progress of rural communities, by encouraging the scientific study and investigation of the conditions which contribute to their social and economic advancement, and by spreading knowledge and stimulating public opinion on the vital importance of a strong farming and rural community to the maintenance of the National life as a whole." 
Sir Horace Plunkett's schemes include, in fact, not only the spread of agricultural organisation in Ireland, but a comprehensive reconstruction of rural life in its various phases with a view to retaining people on the soil, and to rendering existence in the country districts at once more pleasurable and more profitable. It was his ideas on this subject that inspired those views thereon of Mr. Roosevelt of which mention is made on pp. $45-46$

There has now, also, been established in Ireland an organisation known as " The United Irishwomen," which, operating in affiliation with the Irish Agricultural Organisation Society, is to supplement the activities of the sterner sex, and operate on lines akin to those of the hundreds of Women's Institutes at work in Canada, devoting its own energies more especially to (I) agriculture and industries ; (2) domestic economy; and (3) social and intellectual development. It is felt that in all three departments there is much that women could do for the betterment of rural conditions in general, and the scheme in question, first started by Mrs. Harold Lett, at Bree, co. Wexford, on June I5th, I9Io, has since developed into a central union and branches under the control of an executive committee meeting in Dublin. Details concerning this most interesting movement will be found in a sixpenny pamphlet on "The United Irishwomen: Their Place, Work and Ideals," published by Maunsel \& Co., Dublin. 


\section{CHAPTER V. \\ EVOLUTION OF THE AGRICULTURAL ORGANISATION SOCIETY.}

\section{A.-EARLIER EFFORTS.}

So far as can be ascertained, the initial effort in the direction of bringing about a general resort in Great Britain to agricultural organisation, on co-operative as distinct from commercial lines, was made by the Council of the Central and Associated Chambers of Agriculture, which, on December 9 th, I89I, appointed a Committee " to consider and report by what means the organisation of the Chambers could be utilised so as to promote the co-operative principle for the benefit of all its members in the purchase of farming requisites." This Committee, of which Mr. W. Lipscomb was the chairman and Mr. R. H. Rew was secretary, presented, on January 3 Ist, I893, a report which was adopted by the Council and circulated among the associated Chambers. The "conclusions" given in the report are of some interest as showing the point of view from which the subject of agricultural co-operation was regarded at that date. They were as follows :-

Your Committee, having regard to the opinions expressed by Mr. Greening and Mr. Martyn, and to other facts which have been laid before them, do not consider that any scheme taking the whole country for its area, and directed from one centre, could be usefully adopted, but that the several districts of the associated Chambers and Clubs throughout the kingdom would in most cases provide suitable areas for co-operation.

Your Committee desire to call attention to the fact that there are already existing in some localities agricultural co-operative associations which might be utilised, and where such do not exist your Committee have been given to understand that the Agricultural and Horticultural Association would be prepared to accept the single subscription of the secretary of an associated Chamber 
or Club to enable all the members to secure the benefits of membership of that Association.

Your Committee are of opinion that the basis of " Cash with Order " is essential to the success of any scheme for co-operative purchase, and that an annual subscription per member of $5 s$. is all that is needed. The articles in regard to which co-operative purchase can be most advantageously adopted are manures, feeding stuffs, seeds and implements.

Your Committee have been strongly impressed by the information laid before them, with the advantages which may accrue to farmers by the adoption of the principle of co-operation. It is evident that with careful management the risk of failure is small, as is proved by the fact that, so far as they have been informed, no agricultural co-operative association formed for the purpose of purchasing farming requisites has failed. Your Committee, therefore, very strongly urge the consideration of this subject on the members of the Central and Associated Chambers of Agriculture, in the belief that not only might articles of guaranteed quality be procured at prices less than individual purchasers can as a rule be charged, but that by incorporating this object among the primary functions of farmers' associations an incentive to combination will be provided, and a greater union of the agricultural community will be secured.

Your Committee recommend that they be re-appointed, so as to enable them to give further consideration to the subject when the views of associated bodies have been more fully expressed. They are further of opinion that, if successful in the establishment of co-operative associations for the purposes of purchase, such organisations would almost certainly conduce to their utilisation for purposes of sale, especially of those products for which the price now paid by the consumer is so strikingly in advance of that received by the farmer.

These recommendations attracted some degree of attention among the Associated Chambers and Farmers' Clubs, but the Committee was not re-appointed, and the matter remained practically in abeyance, as far as the Central Chamber was concerned, until March $3 \mathrm{rd}$, I896, when, as will be shown later on, further action was taken. Meanwhile there had been important developments in other directions.

\section{National Agricultural Union.}

On December 7 th, 1892 , there was held in St. James' Hall, Piccadilly, a "National Agricultural Conference" which was described in The Times as the outcome of "perhaps the 
most striking movement in the world of agriculture which has taken place in our time."

About two months earlier the Lancashire Federation of Farmers' Associations had suggested to the Central Chamber of Agriculture that a national conference should be held in London to consider the subject of the then seriously depressed condition of agriculture. The Central Chamber sent out a circular on the subject to its affiliated organisations, and " never did an idea catch on," The Times further declared, " with greater spontaneity; never did a movement of the kind take such wide and general root in so short a time." An organising committee was formed, of which Mr. R. H. Rew, who was then associated with the Central Chamber, was appointed secretary, and the conference was held, on the dates mentioned, " ( $\mathrm{x}$ ) to direct public attention to the present grave conditions of agricultural affairs, and (2) to ventilate the grievances under which agriculture labours, and to consider suggestions for their removal." No fewer than 240 societies, clubs or organisations interested in agriculture, directly or indirectly, sent representatives; peers, M.P.'s and great landowners, either as delegates or because of their occupying distinguished positions in the agricultural world, attended to take part with farmers and agricultural labourers in considering how a national problem could best be solved ; and a gathering of about 2,000 persons would have been larger still if more could have been accommodated.

Various remedies for the "sore straits" into which, in the view of the conference, agriculture had fallen were urged, these remedies including currency reform, relief in regard to taxation, changes in land tenure, etc.; but a resort to Protection, in order to counteract foreign competition, was the proposal that evoked the greatest degree of enthusiasm. A resolution in favour of imposing on foreign imports " a duty not less than the rates and taxes levied on home production" was met by an amendment, proposed by Mr. Bear, and seconded by Mr. Yerburgh, M.P., declaring that, as it was of paramount importance that the agricultural 
classes represented at the conference should present an undivided front to the country, it was desirable that discussions on questions which, like Protection, were certain to cause strong division among those classes, should be deferred, and that those questions in respect of which agriculturists were practically unanimous should be pressed forward instead. The amendment was, however, defeated by a large majority, and the carrying of the Protection resolution was greeted with loud cheers. Another of the resolutions passed by the conference endorsed the principle of $\mathrm{Bi}$ metalism. Still another, proposed by Lord Winchilsea, was as follows :-

" That, in view of the present crisis, it is imperative forthwith to establish an Agricultural Union, composed of all persons of different classes who are interested in the land of the United Kingdom, in order (I) to give effect to such resolutions as may be passed by this conference; (2) to frame such measures as may from time to time be needful in the agricultural interest; (3) to organise its members into a compact body of voters in every constituency pledged to return without distinction of party those candidates agreeing to support such measures; (4) to promote the co-operation of all connected with the land, whether owners, occupiers or labourers, for the common good."

If, said Lord Winchilsea, in proposing his resolution, the agricultural interest were organised in the way he advocated, he believed they would be able to return a member for every county constituency in the United Kingdom.

The formation of a National Agricultural Union on the lines advocated by Lord Winchilsea was the one practical outcome of this altogether unique National Agricultural Conference, the story of which deserves to be now recalled because it shows so clearly what were the ideas then prevalent as to the way in which agricultural conditions could best be met ; though a leading article in The Times of December 8th warned the conference that it was " not by such means" as Protection and Bimetalism that the British agricultural classes could hope to recover any portion of their prosperity, saying, further :-

They are confronted with a great economic crisis largely 
brought about by causes quite beyond their own control. They are in a situation not unlike that which visits the commercial community when some great change in the traditional course of business has brought loss, and, it may be, ruin to hundreds through no fault or error of theirs. In such cases men of intelligence and resource recognise that there is only one way by which they can hope to recover any part of their former welfare. They acknowledge that the change is due to the operation of economic principles; they study those principles and set to work to readjust their business as speedily and as completely as possible to the novel conditions which regulate its course. The Agricultural Conference unhappily seems to have made up its mind to defy the recognised laws of economic science instead of endeavouring to adapt their farming methods to them.

Some years were to elapse before this alternative policy of action based on sound economic principles was adopted, and in the meantime active efforts were made by Lord Winchilsea and his supporters to gain wide-spread adhesion to the National Agricultural Union, the specific objects of which comprised the following items :-

I. Reduction in local taxation of agricultural property.

2. Abolition of preferential railway rates on foreign to the prejudice of British produce.

3. Old age pensions.

4. Amendment of the law relating to the adulteration of food and the Merchandise Marks Act.

5. Amendment of the Agricultural Holdings Act.

6 . Increased facilities for the obtaining of small holdings.

This programme was accepted by 230 members of the then new Parliament, in which Lord Rosebery was Premier, and Lord Winchilsea realised his aspirations to the extent of seeing formed an Agricultural Party which represented all shades of political opinion.

Among the agriculturists of the country, however, there was developed a feeling that something more than Parliamentary action or agitation was needed to improve their position. Complaints were then being more especially made against the railway companies, whose alleged undue preference of foreign over British produce was a much-discussed grievance which, as will be seen, had found expression in the second item on the National Agricultural Union programme. 


\section{Action by Great EASTERn RaIlway.}

It was this particular phase of the controversy that lead to an invitation being addressed by Lord Claud Hamilton, chairman of the Great Eastern Railway Company, to Lord Winchilsea and a few leading agriculturists representing the district served by the Great Eastern Railway to meet the directors and the principal officers of the company at Liverpool Street Station on October 2oth, 1895, with a view to ascertaining in friendly conference whether the railway company could do anything to help the agricultural interest. Lord Claud Hamilton was accompanied at the conference by the deputy chairman, Colonel Makins, and various of the company's officers, while the agriculturists were represented by, among others, the Earl of Winchilsea, Sir Walter Gilbey, president of the Royal Agricultural Society, Mr. M'Calmont, M.P., Captain Pretyman, M.P., and Mr. T. Hare, M.P.

On the part of the railway company it was pointed out that while there should, in the interests of all parties concerned, be a certain co-operation between the railways and the producers, it was also essential that each side should have its distinct organisation. The railways had organised a carrying service, and it was for the producers, in turn, to organise their consignments for delivery to the railways and for subsequent sale. The greater economy to a railway company in dealing with large or bulked instead of an equivalent weight of small and separate consignments was pointed to, and the fundamental principle was laid down that, if the railways were to help agriculture, agriculture should, in turn, facilitate the operations of the railways. To this end Lord Claud Hamilton recommended that there should be opened at leading stations in the agricultural districts served by the Great Eastern Railway Company depôts to which the farmers of the locality could send their produce in order that, through combination, they could secure the lower rates for large collective consignments.

On the part of the agriculturists these proposals were 
cordially approved, and a few days later it was announced that a co-operative association was being formed for the purpose, among other things, of establishing depôts, as suggested.

At a further conference, a fortnight later, Lord Claud Hamilton announced that, as a means both of enabling farmers to send supplies direct to consumers and of solving the problem of returned empties, his company had decided upon the adoption of a new system for the carriage of farm or market-garden produce. Provided that the senders packed the produce in wooden boxes to be purchased from the company-such boxes having so small a value that there would be no question of returning them-and fulfilled certain specified conditions, the company would carry the produce from close on roo of their country stations at substantially lower rates, to include delivery to the consignees.

This " box system," as it came to be known, met at first with much favour. In March, I896, it was announced that the Great Eastern Railway Company would apply the system to the whole of their stations in agricultural districts, that is to say, to 300 stations instead of 100 ; and that, with the help of their station masters, they had, with a view to putting producer and consumer into more direct communication, compiled a " List of Producers in Cambridgeshire, Essex, Hertfordshire, Norfolk and Suffolk" who were willing to supply farm and dairy produce to householders in the towns. The list contained 600 names and addresses and stated the different kinds of produce which could be supplied.

Other leading railway companies (as will be shown later on in the Chapter dealing with "Transport Questions") followed the example set by the Great Eastern alike in endeavouring to secure combination among the farmers for the purposes of joint consignment, in the establishing of the "box" system, and in endeavouring in other ways to forward the interests of agriculturists.

In regard, however, to combination, it was subsequently stated that although some of the companies went to a great 
amount of trouble, and also to considerable expense, the result of their efforts in this particular direction was little better than a complete failure.

\section{British Produce Supply Association.}

In the meantime, Lord Winchilsea had matured his plans for a British Produce Supply Association which, formed under the auspices of the National Agricultural Union, and registered in March, I896, was looked upon by the more sanguine of its supporters as likely to lead to a " new era" for the British farmer.

The objects of the Association were thus explained by Lord Winchilsea in an article entitled "Co-operation for Farmers," published in the "British Producers' Handbook": -

The object of the Association is to assist the producer in the disposal of his produce at every stage from the farm to the market. This it proposes to do in the following ways:-

I. By establishing depôts for the direct sale of agricultural produce, and by selling also, on commission, through salesmen of its own stationed in London and in the principal provincial markets. By this means the farmer, instead of being obliged to consign his produce to salesmen of whom he often knows little, and whose returns he has no means of checking, can send it to an Association established in his own interest, and thus have a satisfactory guarantee that it makes all that it is worth.

2. By establishing from time to time depôts at convenient centres in country districts, where produce can be collected and consigned to whatever market furnishes the best demand at the moment. This arrangement will, it is hoped, in due course enable the Association to obtain from railway companies the same rates for the carriage of home produce which are now granted almost exclusively to foreigners.

3. By establishing, in connection with one or more of the depôts according to the nature of the district, an abattoir or a butter factory, which will answer the double purpose of effecting a further and important economy in the treatment of meat or butter produced in the locality, and of serving as models for the imitation of associations of farmers in other parts of the country which might desire to follow in the footsteps of the parent Society, and, while erecting their own abattoir or butter factory, as the case may be, to avail themselves of its services for the ultimate disposal of their produce in the market.

4. It aims at gradually organising a better system for the collection of produce in rural districts surrounding the depôts, a 
system which may, of course, be made available as an outlet for many rural industries not immediately connected with agriculture, but scarcely less valuable as a means of providing occupation for labourers and their families during the winter.

Registered as a limited liability company, the Association started with a capital of $£ 50,000$. At first the raising of $£ 250,000$, to allow of operations being carried out on a much larger scale, was contemplated; but the original plans were modified for reasons thus explained in an article on "A British Produce Supply Association," which I was privileged to contribute to The Times of March I6th, I896:-

The reason for this limitation is the idea that, inasmuch as the initial efforts will be largely experimental, it would be better not to attempt too much at once, and to keep in the background for a time a much more ambitious scheme which might be developed all the better later on, if the promoters had from the first gained experience from actual working on a smaller scale. But the Association will, none the less, start under favourable auspices. The directors are the Earl of Winchilsea (President of the National Agricultural Union), Lord Kesteven, Mr. R. R. B. Orlebar, Mr. R. H. Rew (secretary of the Central Chambers of Agriculture), and $\mathrm{Mr}$. Cornelius Thompson (late chairman of the committee of the Civil Service Supply Association), while the following, among others, have expressed approval of the objects in view :The Duke of Portland, the Marquis of Huntly, Earl Brownlow, the Earl of Denbigh, the Earl of Jersey, Earl Stanhope, Lord Herries, Lord Wantage, the Marquis of Hertford, Mr. James Lowther, M.P., Mr. J. K. W. Digby, M.P., Mr. M. D'Arcy Wyvill, M.P., Mr. Alexander Henderson, Mr. W. More Molyneux, Mr. R. H. Wood, Mr. James Rankin, M.P., Mr. W. H. Hall, and Mr. R. A. Yerburgh, M.P. The secretary is Mr. William Broomhall, and the offices (pro tem.) are at 30, Fleet Street. As we understand, the public is not to be asked to subscribe until experience has proved the practicability of the scheme.

For the collection of produce in the country, an agent of the Association was to be stationed at some convenient market town where, with funds provided weekly by the Association, he would purchase supplies direct from the farmers, who were to be guaranteed better prices than they would be likely otherwise to obtain locally, and be saved the trouble of themselves sending their produce away. The agent would have a depôt at the local railway station, and he would there bulk the consignments and get the advantage 
of lower railway rates. It was expected also (to quote further from the article in The Times) that "the Association's agent would be a sort of technical educator, inasmuch as he would point out the faults of the produce he could not purchase, and would distribute leaflets and printed instructions as to what the Association wanted, and how things should be done. Hitherto," it was added, "with purely local prices, one farmer has had no inducement to offer better commodities than another, but this will be altered when the Association's agent practically takes the London market into the country." Butter obtained from cooperative dairy factories (the Association doing all it could to encourage the starting of more of such factories), and sent to London, would be graded and sold under a brand which would be a guarantee of purity and of British production. In addition to the abattoirs at which the Association would kill its own meat, bacon factories were to be established.

In regard to sale, the Association was to start with a depôt of its own in London, to be followed by others in Birmingham, Leeds, Manchester, and other large towns.

In the country operations were begun at Sleaford (Lincolnshire), where a local Association was formed. In London some commodious premises were taken in Long Acre, in convenient proximity to Covent Garden and other markets, and these were fitted up on the "stores" system, with the addition of a club room for the use of shareholders and of members of the British Produce League, which had been established to encourage the use of British products and the employment of British labour. It was hoped that the wholesale dealers would support the movement when they realised "the practical benefits that the Association aimed at securing in the interests of the British agriculturist"; but it was intimated that, if the "trade" held aloof, the Association was "fully prepared to deal on a widespread basis direct with the consumers."

The Long Acre depôt was opened in October, 1896, and at the outset a good business was done; but difficulties 
began to be experienced from the start, and they increased almost daily in magnitude.

Producers in the country sold their best qualities to the ordinary traders, and expected that an Association started in the interests of agriculturists would give them a good price for their second-rate qualities. They felt hurt when their supplies were rejected, and still more so when the local agent started on his educational work of teaching them what they ought to do. One or two other local Associations were formed, and model rules were drawn up, in the hope that still more would follow; but the progress made in this direction was very slight.

In London itself, Society had shown much sympathy towards the scheme while it was being projected; but dwellers in the West End found it inconvenient to deal with a depôt so far away as Long Acre, and when it was sought to overcome their objections in this respect by the opening of a West End branch, they would still make no allowance for those who could not supply exactly what they wanted, while the plea that it was "British grown" did not incline them sufficiently to accept produce that was not to their liking.

The wholesale traders equally failed to show their patriotism in studying the interests of the British agriculturist when those interests seemed to conflict with their own business. Failing to make satisfactory arrangements with the salesmen in various wholesale markets, so that produce which could not be disposed of at the depôt might be sold on commission, the Association obtained stalls of its own in Covent Garden Market and the Central Meat Market; but once more it was faced with troubles and difficulties.

In the result heavy losses were sustained. They amounted at times to as much as $£ 250$ a week ; and it became evident that failure could not be averted. The original Association -which, it will have been seen, in no degree represented co-operative effort-was dissolved, and a new one took over what was left of the business; but the idea of having direct dealings with farmers in the country districts was almost 
completely abandoned. Lord Winchilsea died on September 7 th, I899, his health having broken down as the direct result of his excessive zeal in the interests of British agriculture.

\section{REASONS FOR FAILURE.}

With the wisdom that comes after the event, the reasons for the failure of the well-intentioned efforts on the part alike of Lord Winchilsea and of the railway companies can easily be given.

Inquiry into the conditions under which the organisation of agriculture had been successfully carried out in other countries showed that a beginning had invariably been made with the simplest forms of combination, and more especially with combination for the joint purchase of agricultural necessaries. In this way the advantages of cooperation could be brought home to cultivators, who were gradually educated in the theory and practice of combination without having their suspicions aroused and their mutual distrust stimulated by proposals that they should at once alter their old conditions of trading in accordance with that system of combination for transport or sale which really constitutes, not the beginning of agricultural organisation, but one of the most difficult and most complicated of all its many phases.

In the circumstances it was not surprising that the earlier efforts here in question should have failed to secure the desired results. While, also, they so far influenced public opinion as to modify the popular view that " the railways were the chief stumbling-block in the way of the development of British agriculture," and to show that the most practical means of effecting this development would be found in agricultural organisation, these initial failures left the impression that it was hopeless to attempt to secure that remedy here because, as was said, "British farmers won't combine." Thus the task to be attempted later on by others who were convinced that British farmers would combine if only they were approached in the right way was rendered 
even more difficult than it would otherwise have been. None the less had it been made evident that the task was one to be accomplished, if at all, by an independent organisation, working on purely propagandist lines, and not only undertaking duties far beyond the scope of a railway company's activities, but also avoiding the risks and complications of actual trading.

Before this was done, however, there was to be a renewal of efforts by the Central and Associated Chambers of Agriculture.

\section{CHAMBERS OF AGRICULTURE INQUIRY.}

On March 3rd, I896-that is to say, in the same month as that in which Lord .Winchilsea's British Produce Supply Association was registered, and at a time when agricultural organisation was very much " in the air "-the Council of the Central and Associated Chambers resolved, by a majority of $2 \mathrm{I}$ to 8 , " That this Council recognises the desirability of promoting combination for the sale and distribution of farm produce, and for the purchase of farm requisites " ; while in the following November the Council further resolved, "That a Committee be appointed to enquire into the extent to which the principle of co-operation has been applied in this and other countries to the sale of agricultural produce; whether it is feasible and desirable to promote its further extension; and, if so, what means are best adapted to that end." The Committee was constituted thus:-The Rt. Hon. J. L. Wharton, M.P., the Rt. Hon. (now Sir) Horace Plunkett, M.P., Mr. D'Arcy Wyvill, M.P., Mr. R. A. Yerburgh, M.P., Mr. W. H. Barfoot-Saunt, Mr. J. Bowen-Jones, Mr. T. Latham, Mr. W. Lipscomb, Professor Long, Mr. Clare Sewell Read, and Mr. S. Rowlandson, with the subsequent addition of Lord Wenlock, Mr. F. E. Muntz and Captain Stuart-Wortley, R.N., while Mr. R. H. Rew, who took an active part throughout in this further phase of the movement, was once more appointed to the position of secretary. At the outset of their enquiry the Committee invited the 
assistance of various authorities on the questions within the terms of their reference, and the following attended the meetings held, and gave the Committee the benefit of their experience :-Mr. M. R. Margesson, British Produce Supply Association; Mr. R. A. Anderson, Irish Agricultural Organisation Society: Mr. Algernon Fawkes, late agent to Lord Vernon; Mr. F. E. Walker, Escrick Dairy Factory ; Mr. R. T. Haynes, South Shropshire Farmers' Trading Association; Mr. Alec Steel, Eastern Counties Dairy Farmers' Society; and Mr. H. Cecil Wright. The Committee further convened a conference on agricultural co-operation, held in the rooms of the Society of Arts on December 8th, 1897. Representatives attended from many different associations, and among those who were also present were Mr. (now Sir) T. H. Elliott, C.B., Secretary, and Major Craigie, Assistant-Secretary of the Board of Agriculture. The main purpose of the conference was to consider " the question of the desirability and feasibility of extending the principle of co-operation for the purchase of farming requisites and the sale of agricultural produce, and the means best adapted to that end." It was thought that the chief object in view had been attained by the practical nature of the speeches made, while the direct outcome of the proceedings was the passing of a resolution as follows :-

That this conference considers it is desirable to establish some form of communication between the various British and Irish co-operative agricultural organisations, and respectfully requests the Central Chamber of Agriculture to initiate this movement by calling representatives together on a future occasion.

The report eventually issued by the Committee included a detailed account of agricultural co-operation ( $\mathrm{I}$ ) in Great Britain, (2) in Ireland, (3) on the Continent, and (4) in the United States, Canada and Australasia ; and it further gave certain conclusions at which the Committee had arrived. Corroboration was found for the view previously expressed by the Central Chamber, "that cooperation for purchase and co-operation for sale form two separate problems, and that the solution of the one is easy 
while that of the other is extraordinarily difficult." The Committee endorsed the recommendation that local associations for the co-operative purchase of farming requisites should be increased, and thought that "in many cases the functions of such an association would form a fitting branch of an existing Farmers' Club or Chamber of Agriculture." In regard to co-operation for sale they considered that, notwithstanding the admitted difficulties, associations of producers in particular districts for the joint disposal of certain classes of produce would be advantageous ; and they proceeded :-

It is not to be expected, however, that such associations will arise spontaneously. They are only likely to be started, even where they may be most desirable, as the result of an organised and systematic mission to explain the principle of co-operation, the probable advantages of its adoption in each particular case, and the constitution, rules, and procedure which must be accepted and followed if the harmonious and successful working of cooperative associations is to be assured. In short, work similar to that done in Ireland by the Irish Agricultural Organisation Society would need to be done in this country by a purely propagandist body.

The Committee hesitate, however, to recommend an addition to the numerous agricultural associations already existing, the more so as they are of opinion that the end would be better attained by utilising to some extent the machinery of the Central Chamber of Agriculture, which already stands in some respects in an analogous position to the Irish Agricultural Organisation Society.

Finally, the Committee recommended the Council of the Central and Associated Chambers of Agriculture to constitute a "Co-operation Section," which should comprise all deputies and subscribing members of the Chamber desirous of joining it, and should have power to take action, within defined limits, and without committing the Chambers as a whole, for the promotion of the principle of co-operation in agriculture.

In the light of subsequent developments, one may well wonder what the history of agricultural co-operation would have been if the movement had been directed and controlled by the Central Chamber of Agriculture as here suggested. 
In effect, however, the great services which the Chamber had already rendered in helping to direct public attention still further to the general subject were not to fructify into a definite carrying out of the scheme projected, and the actual establishment of agricultural co-operation as a national movement was to be brought about under widely different conditions.

\section{British Agricultural Organisation Society.}

In I900, there was formed at Newark, Nottingham, by Mr. W. L. Charleton, a British Agricultural Organisation Society based on lines akin to those of the Irish Agricultural Organisation Society.

\section{The Agricultural Organisation Society Formed.}

Within a year of this British Agricultural Organisation Society being established, the decision was arrived at to unite it with the National Agricultural Union, and form a new body, to be called the Agricultural Organisation Society. Mr. R. A. Yerburgh, M.P., one of the earliest of Lord Winchilsea's supporters, a member of the Central Chamber of Agriculture's Committee on Co-operation for Purchase, and then President of the National Agricultural Union, accepted the position of President of this new body on the understanding that it adopted co-operation as its fundamental principle $;{ }^{1}$ and it is in accordance with this understanding that the operations of the Agricultural Organisation Society, brought into existence as the final outcome of the series of events here narrated, have been conducted ever since.

\section{B.-PROGRESS AND DEVELOPMENT.}

Registered in April, I9or, under the Industrial and Provident Societies Act, the Agricultural Organisation

$1 \mathrm{Mr}$. Yerburgh had previously marle it a condition of his acceptance of the presidency of the National Agricultural Union that that body should abandon "Protection and Politics." 
Society-otherwise the "A. O. S." - was constituted as a non-party and non-trading body, whose main purpose was to " secure the co-operation of all connected with the land, whether as owners, occupiers or labourers, and to promote the formation of agricultural co-operative societies for the purchase of requisites, for the sale of produce, for agricultural credit banking and insurance, and for all other forms of co-operation for the benefit of agriculture." The Society adopted, in fact, on its own account, the principle which had been enunciated by Sir Horace Plunkett at the inauguration of the Irish Agricultural Organisation Society, in I894, when he said:- "The keynote of our proposals is in the proposition that the farmers must work out their own salvation, and, further, that this can only be done by combination among themselves."

While, however, public opinion was, by this time, fully prepared to endorse the soundness of the argument, it greatly doubted the possibility of carrying the proposals into effect. It sympathised with the idea of combination among British farmers, but assumed, from the recent experiences, that those who made further attempts to attain the realisation of that idea would simply be following up a forlorn hope.

There did, also, appear to be a certain amount of presumption on the part of the new Society.

The National Agricultural Conference of December, I892, had brought together the greatest authorities in the British agricultural world, and these had proposed their remedies and blessed the formation of a National Agricultural Union ; but the remedies were found to be of no avail and the National Union came to nought.

Lord Winchilsea had organised his British Produce Supply Association with a capital of $£ 50,000$, had secured the support of leading members of London Society, had started operations on an ambitious scale, and had then-failed.

The railway companies, with all their powerful resources, had in turn sought to promote combination among the farmers, and they, too, had-failed.

Notwithstanding these failures, an unpretending little 
Society which, at the outset, occupied two small rooms in a block of offices situate in a side street in Westminster, and had at first hardly enough funds with which-apart from the voluntary efforts of an active committee-to pay rent, a secretary, a typist, and the charwoman, and distribute leaflets in addition, had started on no less formidable a task than, not merely inducing British farmers to combine, but practically reorganising their industry, with possibilities of exciting the prejudices, or of arousing the opposition, of powerful commercial interests concerned to the extent of many millions in the allied industries on which agriculture was more or less dependent. Yet the said Society, based on sound principles, and increasing in strength as the years went on, was to attain to such success that it represents to-day a national movement which has not only already achieved important results, but, with the process of reconstitution it has just undergone, should enter upon a fresh and greatly expanded career of practical usefulness alike to agriculture and to the country in general.

The first secretary of the Society was Mr. A. T. Matthews, who had acted as secretary to the National Agricultural Union. Mr. J. Nugent Harris, the present secretary, began his connection with the Society in July, I9or, when he was appointed as dairy expert. Three months later, on Mr. Matthews resigning his post as secretary, Mr. Harris succeeded him in that position.

\section{EARLY DAYS.}

At the outset there was naturally a great amount of spade work to be done in preparing the foundations of a system of agricultural organisation designed, at first, to cover not only the whole of England and Wales, but Scotland as well; though, as will be told in detail in the section on "Devolution," the work of carrying on organisation in Scotland from the London headquarters through a small staff, controlling inadequate finances, was so arduous that the A. O. S. readily joined in the setting up, in 1905 , of a separate organisation for Scotland. 
In these early days even that very word " co-operation," which constituted the fundamental principle of the movement, was misunderstood, and is, in fact, still widely misunderstood even to-day. There were, in Igor, already in existence many Farmers' Trading Companies, Farmers' Auction Marts, Farmers' Insurance Companies and other combinations with the prefix "Farmers" ; but although some of these were genuine co-operative bodies, they were mostly limited liability companies whose gains benefited shareholders not themselves necessarily agriculturists or interested in agriculture apart from the dividends they received. When such combinations failed, or did wrong things, they brought discredit on co-operation because they had quite wrongly annexed that designation; but they were not really co-operative societies in the sense implied in the following explanatory statement contained in a letter sent to the Press by the A. O. S. :-

The best way to form an agricultural co-operative society is to register under the Industrial and Provident Societies' Act, and so to frame the rules that the amount of the nominal capital is not fixed ; that shares can be allotted at any time to any farmer apply. ing for them ; that the interest payable upon the capital is limited to a small percentage, usually 5 per cent., thus preventing the concern from becoming a mere investment for capitalists; and that the bulk of the profits is divided amongst the members as a bonus upon the amount of their sales through, and purchases from, the society.

Then, however hopeless the prospect of the Society's success may have appeared to many persons, considerable interest was attracted to it even in the first year of its existence. This interest was especially stimulated by the issuing of the following statement (subsequently modified in certain of its details) as to the actual lines on which it was prepared to carry out the fundamental principles already mentioned :-

x. By sending down organisers to address meetings and to give advice as to the proper course to be pursued in the formation of local societies.

2. By providing model rules which have been found by experience to be the best working rules for all similar societies. 
3. By sending down lecturers, when desired, to affiliated and other societies.

4. By acting as an information bureau to affiliated societies-

(a) For expert advice.

(b) For legal matters (especially as regards Industrial and Provident Societies).

(c) For co-operative account keeping.

5. By arbitration in disputes arising from the rules and administration of affiliated societies.

6 . By assisting in all ways possible the furtherance of combined action between the various affiliated societies in trading matters.

7. By publishing leaflets and circulars from time to time dealing with the various forms of agricultural co-operation, and furnishing trade information.

This was, in the circumstances, an ambitious programme for a young Society, and the work of the early days was naturally imperfect in many directions by reason of insufficient staff and means and the difficulties presented by having both to face the prejudices of generations and to win over the agricultural mind to entirely new ideas. All the same, a certain degree of success was secured from the start, and the progress made, however slow, was sure.

At the end of the first year of its operations, there were already in affiliation 33 societies, some of which had been formed by the British Agricultural Organisation Society, previously to the registration of the A. O. S., though most of them had been established subsequently thereto.

\section{Financial Position.}

In addition to affiliated societies, the membership included individual subscribers to the funds; yet even with this support the question of finance presented serious difficulties, so much so that in the report for 1903 it was said :-

Out of the small income, a little more than $€ 700$ per annum, which is at the disposal of the Committee, we have to provide a secretary, suitable offices, clerical assistance, trained organisers to give expert advice to local societies, and to furnish, without stint, information by means of printed matter, etc. This can only be done by the employment of men with special knowledge and experience, and to secure their services due remuneration and travelling expenses are obviously necessary. 
The insufficiency of funds was, in fact, at this time, and for some years afterwards, a constant nightmare to those concerned in the task which had been undertaken, and a great debt of gratitude is due to those who so loyally supported the Society in this anxious period by money and by personal service. The work had to go on, whatever the difficulties, and it was impossible to retrench in face of the ever-increasing need for further expenditure to meet new developments or even the natural expansion of what had already been taken in hand.

\section{Methons of Operation.}

How the A. O. S. started on its task of organising the agricultural industries of the country may be illustrated by some references to its second annual report, for I902; and it will further be seen therefrom how materially the methods of the Society differed from those that had previously been adopted in this country.

A very good beginning indeed had been made in the Midlands. Five societies had been registered there; a conference on organised co-operation in agriculture had been held at Worcester under the auspices of the Agricultural Sub-Committee of the Worcestershire County Council and the A. O. S., and the movement was being eagerly discussed on all sides. In the way of accomplished results it was reported that certain of the societies had come into considerable prominence owing to the vigorous action they had taken in breaking up some rings formed by dealers who had sought to control the green pea and cherry markets. One of these societies had acquired the apples and pears in a number of orchards, had had the fruit gathered by trained fruitpickers, and, utilising a large warehouse, had made up, not only such consignments as the railway people preferred to handle, but consignments properly graded and packed, and likely, therefore, no less to satisfy the dealers. Plums, damsons, and blackberries, together with potatoes, carrots, and other vegetables had been graded and dealt with in the same way, the declared experience of the society being that 
" highly-graded produce, of which the dealer can be assured a continuous supply of a uniform quality, will command a considerably higher price in the market than mixed produce, however good; and as no one man can possibly pack and grade the crop of his own place, unless he is a very large grower, co-operation offers the true means of competing with foreign products."

\section{Progress in WALES.}

The report for the same year (1902) shows that " remarkable progress" had been made in Wales. There were then in the Principality eleven co-operative agricultural societies, most of which had been formed mainly for the co-operative purchase of agricultural requirements. Four had directed their attention to live stock improvement, procuring pedigree bulls and boars, and others, which had sought to organise collective sale, had been successful in combating a "ring" among the poultry salesmen. One society, not registered until February, I902, had nearly 400 members by the end of the year, had had a turnover of $£ \mathrm{I}, 600$ and had made a profit of $£ 200$ in dealing with fertilisers, seeds, etc., though it had done so in face of the keenest competition; and it had just taken over from a local dealer some premises which contained a gas engine and a mill for grinding maize, barley, etc. A store-keeper had been appointed, a trade agent was to be engaged to act as an organising secretary, a weekly pig market was to be started; a comprehensive live stock improvement scheme was being planned; the store already mentioned was to be further used as an eggcollecting depôt ; and steps were being taken to improve the breed of members' poultry, a stock of the best winter-laying birds having already been obtained. The other societies were operating more or less on similar lines, and it was reported in regard to the general movement in Wales that, by the formation of these societies, a saving of from 20 to 25 per cent. had resulted to the farmers who were members of them, while a further effect had been experienced in the bringing down of prices all round wherever the starting of 
a society was projected. On the other hand the societies had had to meet " a most powerful trade opposition," and it was thought better to establish firmly and consolidate the societies already existing in Wales rather than respond too eagerly to the requests daily coming to hand for the formation of new societies.

One further result of the work in Wales that might be mentioned was the remarkable change in the quality of the seeds, fertilisers, etc., supplied to the districts where the agricultural co-operative societies had been in operation for any length of time. In the days prior to organisation as an active force in agriculture, Wales and Ireland were alike the common dumping grounds for the refuse and the "cleanings" of seeds and for the poorest qualities of fertilisers from England and Scotland ; but the tests, analyses or guarantees instituted or insisted on by the societies, together with the rejection of inferior supplies, led to changes in methods from which farmers outside the organisation movement benefited -as they are doing to a still greater degree to-day-no less than those who had given it their support. ${ }^{1}$

\section{Advantages of the New ORganisation.}

These examples may serve to illustrate the general lines on which the Society started its operations. There was already in existence a considerable range of societies which had been formed (as distinct from commercial undertakings) to promote in various ways the interests of agriculture, horticulture and allied industries, but none of them fulfilled the same purpose in enabling the British farmer to (I) produce to the best advantage; (2) transport to the best advantage; and (3) sell to the best advantage. The Society took up the practical side of agriculture just where the

1 In the gardens of the Royal Agricultural College, Cirencester, there is an experimental plot which gives a practical illustration of the result of using so-called " grass" seeds consisting mainly of cleanings. In one section, planted with cock's-foot grass, the crop produced included wild geraniums, thistles and several turnips. In another section the sheep's fercue grass, which should alone have been seen, was almost entirely obscured by an abundant growth of thistles, plantain, mustard, ox-eyed daisy, hawk weed and medick. 
teachings of science left off, and the economies effected in the joint purchase of agricultural necessaries by a group of producers in Worcestershire or elsewhere; the better control they got of the market ; the obvious superiority of properlygathered and properly-graded consignments on a larger scale; the realising of better prices from sales-these and other advantages, steadily increasing in range and extent as the work underwent still further development, were object-lessons in agricultural combination which could not fail to produce a good effect even where the aforesaid earlier efforts had failed; while the policy followed by the founders of the movement was to establish small local societies, and allow these to form the real basis of an organisation eventually to assume national proportions, rather than to work in the opposite direction by starting a national movement first and the local societies last.

In 1904 the Society enlarged the scope of its operations by absorbing the Co-operative Banks Association, and in 1909 came the taking over of the organisation work of the National Poultry Organisation Society, concerning which more will be said in the section dealing with "Eggs and Poultry."

\section{JOINT BOARDS.}

Down to I908 the agricultural co-operative movement was operated on independent lines by the central societies of England and Wales, Scotland and Ireland respectively; but a conference held in Dublin on June 12 in that year by representatives of the three bodies decided, in the words of a pamphlet subsequently issued by Sir Horace Plunkett, "that some permanent machinery should be established whereby mutual consultation in matters relating to organisation, and united action in matters relating to trade, could be resorted to whenever the work of organising the farmers of these islands seemed likely to be furthered thereby." To this end there were appointed two boards, the one a Joint Board for Agricultural Organisation, and the other a Joint Board for Agricultural Co-operative Trade. The former 
consisted of representatives of the three central soceities, and the latter of representatives of the Agricultural Cooperative Federation, the Eastern Counties Farmers' Cooperative Association, the Scottish Agricultural Organisation Society, the Farmers' Supply Association of Scotland, the North-Eastern Agricultural Co-operative Society and the Irish Agricultural Wholesale Society. Sir Horace Plunkett was appointed chairman and Mr. R. A. Anderson hon. 'secretary of each Board, with Mr. R. M. Drysdale, Mr. F. C. Smith and Mr. John Portnell joint secretaries on trade.

Meetings of the Joint Board for Organisation, held in I908, dealt with various important subjects, including cooperative credit and the relation of the State to agricultural organisation.

It was considered that the matters on which action by the Joint Board for Trade might most successfully be taken were (I) the acquisition of agricultural necessaries of the best qualities at the lowest prices; (2) the marketing of produce in the most economical manner; and (3) the interchange of commodities between the different societies themselves. The Board held three meetings in I908, appointed a sub-committee to report on the conditions in respect to co-operative trade in (a) fertilisers, (b) implements and machinery, (c) feeding stuffs, (d) seeds, and also held an important conference with the Fertiliser Manufacturers' Association. In April, I9o9, the question of the manufacture and supply of feeding cakes was discussed and referred to the sub-committee.

At recent meetings of the Joint Boards a number of important questions have been discussed.

\section{The Plan of Campaign.}

The system on which the business of the A. O. S. was conducted may be briefly indicated as follows :-

I. Advertisement :

(a) Holding of meetings at which addresses on agricultural co-operation were given by the President and members of the Committee, or by members of the staff. 
(b) The issue of leaflets, circulars, reports, etc.; the publication of the "A. O. S. Journal," and communications to the Press.

(c) A system of expert correspondence on matters relating to agricultural co-operation.

II. Organisation of Agricultural Co-operative Societies :

(a) When invited so to do, the A. O. S. sent an organiser to a district to explain the methods of forming and working an Agricultural Co-operative Society.

(b) The A. O. S. supplied its "Model Rules," and attended to the legal formalities of registration by acting as a medium between the Society and the Registrar of Friendly Societies.

III. The assisting of co-operative societies in the following directions :-

(a) Visits by organisers from time to time, or attendance at annual or other general meetings, opportunities being thus afforded for the giving of advice or direction by members of the central staff.

(b) The publication in leaflets, circulars, and in the "A. O. S. Journal " of articles on co-operative subjects and on matters of importance to the administration of societies.

(c) The giving of expert advice by means of correspondence.

IV. Acting as a medium between co-operative societies and Government Departments, County Councils, Railway Companies and other bodies, and watching, in their progress through Parliament, any Bills which might affect the interests of agricultural co-operative societies or their members.

V. General organisation.

In the carrying on of the work on these lines, the societies were also brought into contact with each other by means of district and other conferences, the Joint Board for Trade, etc., these having the effect of encouraging the exchange of experience and information among the societies themselves.

In later years was to come, as will be told in due course, recognition by the State, the carrying out of a " devolution " policy, the building up of many different departments (each of which will here call for separate treatment), removal of offices, and increase of staff, all contrasting strongly with the conditions that prevailed in the Society's early days.

A.O. 


\section{C.-STATE AID AND PUBLIC APPROVAL.}

While the Agricultural Organisation Society had started as a propagandist institution entirely dependent on voluntary contributions, the importance of the work it was doing received early official recognition of a character which, in the circumstances, was especially gratifying and encouraging.

\section{The BoARd of Agriculture.}

At a conference on agricultural co-operation arranged by the agricultural students of the Aberystwith University, and held there on December Ist, I902, the late Mr. R. W. Hanbury, then President of the Board of Agriculture, said :-

I am not only personally in favour of agricultural co-operation, but I think it is an object that ought to be assisted as far as the Government can reasonably assist it. I do not say it is a panacea for all the evils and troubles of agriculturists. . . . The troubles of agriculturists have got to be removed by applying a great number of remedies, and especially those remedies which are suitable to all places. Although co-operation is not the cure-all, although it is not a panacea, upon my honour I believe it comes nearer to being such than a good many of the remedies we sometimes hear of. ... It is the best form of self-help. ... Let farmers consider that theirs is a business. . . . I should like to see the farmers of this country a great deal better organised than they are. . . . You should put pressure upon any Government, by whatever name it may be called, to do justice to this great industry. I therefore ask you, as farmers, to organise and bring pressure upon any Government to see that justice is done.

Mr. Hanbury also attended the first public meeting of members and subscribers held at the Westminster Palace Hotel on April 29th, I902, on which occasion he said, in the course of another most sympathetic speech-

He did not know that pecuniary assistance could be given to the A. O. S. from the State, but he wished by his presence to show that his department was ready to take an interest in their important work, and hoped that the work of both would be brought into closer touch. They would be pleased to render help and information in every way, and he himself would like to become a member. 
By the death of Mr. Hanbury, in I903, the Society lost a good friend; but the late Earl of Onslow, who succeeded him as President of the Board of Agriculture, attended the public meeting of the A. O. S. held at Grosvenor House on May 26th, I903, and declared that he most heartily endorsed the sentiments expressed by his predecessor, adding, "I have the deepest interest in this Association and I intend to do all I can to assist the good work it has in hand."

Lord Onslow's successor at the Board of Agriculture, the Right Hon. Ailwyn Fellowes, was among the speakers at the annual meeting in 1905 , and said he considered that the work which had been done by the Society deserved the sympathy and support of everyone. To his mind there was no better form of co-operative organisation than that which the Society advocated, and the Board over which he presided wished them " all luck and all success." They would find in that Board a body which was absolutely with them in almost all their wishes as regarded agriculture in this country, and they would certainly do all they could to assist them.

When Earl Carrington, now the Marquis of Lincolnshire, succeeded to the office of President of the Board of Agriculture, he was no less sympathetic towards the A. O. S. than his predecessors had been. In a speech he delivered at the annual meeting in Igo6 he said that-

When the taxation of the country and the income tax were reduced, and they had a little money in the till, then with the greatest pleasure he would tackle the Chancellor of the Exchequer and put it before him in the most forcible language that of all the demands which were being made upon him there was not one that deserved more sympathetic and more practical, hearty support than that of the Society of which Mr. Yerburgh was the head. He was glad to have had an opportunity of showing his entire sympathy with, and his practical support of, the co-operative movement, and he could assure them that every member of His Majesty's Cabinet hoped to see a great development of the work of the Society in the future.

Mention should be made, also, of the cordiality shown towards the Society, and the practical help given in many 
ways, by all the leading officials of the Board of Agriculture, and more especially by the Permanent Secretary, Sir Thomas Elliott, whose ever-ready assistance has been of great service in furthering the Society's propagandist work, and helping to place the Society itself on a firmer footing. Most useful, also, were the leaflets issued by the Board of Agriculture from time to time dealing with the A. O.S. or with particular phases of its activities, together with the further references thereto in the Board's official journal.

\section{The Home Office.}

In I903, also, the Home Office granted the prayer of a memorial from the A. O.S., asking for the removal of certain disadvantages under which creameries in Great Britain laboured as compared with creameries in Ireland, by reason of the special exemptions granted to the latter as regarded the employment of women on Sundays.

\section{The TREasury.}

Equal success attended the presentation, again in 1903 , of a joint memorial to the Lords of the Treasury from the Co-operative Banks Association, the Agricultural Organisation Society and the Irish Agricultural Organisation Society for the removal of certain restrictions regarding the registration of Agricultural Credit Societies designed in the interests of small cultivators and the rural labouring class.

It was asked that in view of the essentially "friendly" character of these village societies, coupled with the fact that no profit or dividend is divided amongst their members, there should be an amendment of such regulations as prevented the societies from being registered as, and sharing in the privileges of, ordinary friendly societies. The amendments desired were- (a) Abolition of the $£^{\mathrm{I}}$ fee for registration and of the ros. fee for amendment of rules, these fees, it was pointed out, being " prohibitive to the very poor people it was sought to encourage in the direction of economic self-help"; (b) exemption from stamp duty, as per 
clause 33 of the Friendly Societies Act, and (c) priority of claims against the estates of officers, as per clause 35 of the Friendly Societies Act. All three proposals were acceded to by the Treasury.

\section{Board of Education and County Councils.}

Indirectly, a certain degree of State-aid was obtained in I 902 through an important concession by the Board of Education.

As the result of several conferences between Mr. C. G. Watkins, secretary to the Education Committee of the Bucks County Council and the A. O.S., a representation was made to the Board of Education, on behalf of the Agricultural Sub-Committee of the County Council in question, that instruction in the "Principles and Practice of Agricultural Co-operation "-which subject was not included in the branches of science and art with respect to which grants were then being made by the Board of Education under the Technical Instruction Act of I889-was required by the circumstances of the district.

Mr. Yerburgh also waited specially on the then Permanent Secretary to the Board of Education, Sir George Kekewich, in respect to this application, and there was reason to believe that the representations he made had much to do with the granting of the desired concession by the Board. Following thereon, the Education Committee of the Bucks County Council employed, for three months, one of the organisers of the A. O.S. to give instruction in the methods of agricultural organisation, a society being formed as the result of his labours. A circular letter was issued by the Board of Agriculture to the County Councils of England and Wales, bringing the concession under their notice, and several councils, obtaining like sanction, utilised the services of the Society or took other steps to promote the teaching of the principles and practice of agricultural co-operation.

In Wales, where the interest in the movement had, by this time, become exceptionally keen, the County Councils of 
Carmarthen, Cardigan and Pembroke sent in August, I902, a deputation of 18 delegates to Ireland, where nine counties were visited and close enquiry was made into the working of agricultural co-operation there. The Secretary of the A. O. S. accompanied the deputation, and helped in organising the tour. The Irish Agricultural Organisation Society also gave a good deal of assistance. Much of the success of the tour was due to the untiring efforts of the hon. secretary, Mr. H. Jones-Davies.

In a report subsequently presented for the consideration of their respective County Councils the delegates placed on record their conviction " that the principles of agricultural co-operation, as established on the model of several European countries, and as successfully applied in Ireland, are eminently adapted to further the present condition of agriculture in west Wales, and that their adoption is highly desirable in the farming interest." The delegates thought the comparative failure of the butter factories hitherto established in that part of Wales was mainly attributable to the fact that the elementary principles of agricultural co-operation had not been applied to their formation and subsequent conduct, and they made a long series of recommendations to their Councils with a view to securing the dissemination of these principles in the general interest of agricultural industries in their districts.

The example set by those of the English and Welsh County Councils which had taken up the teaching of the principles and practice of agricultural co-operation was speedily followed in Ireland, so that in this respect, at least, England led the way. County Councils were, indeed, finding that agricultural co-operation was but the logical outcome and practical application of such agricultural instruction as they were already, in many instances, so actively engaged in imparting. The position was put very clearly by one of the County Council instructors in Ireland, who said :- "When farmers have been taught by lecturers and experts everything they can teach them about artificial manures, farm seeds, and feeding stuffs, the farmers naturally want to be 
placed in a position to procure these articles of the very best quality and at the lowest prices."

Among other developments of this action on the part of the County Councils mention might be made of the delivery of lectures under the combined auspices of the Worcestershire County Council and of the local co-operative societies; the inclusion, in I903-4, of "Farmers' Clubs and Co-operation" and "Co-operation in Dairy Work" among the subjects discussed in a series of "Informal Talks" included in the Notts County Council Education Committee's scheme of technical instruction; the formation of a society at Frampton-on-Severn as the result of a lecture on agricultural co-operation arranged by Mr. Turner, director of agricultural education for the Gloucester County Council, the lecturer being an A. O. S. organiser; the delivery in Buckinghamshire of further series of lectures on "The Benefits of Cooperation," by an A. O. S. organiser, in 1907 and I908, under an arrangement with the Bucks County Education Committee; and the lectures arranged by the County Councils of Cambridge, Lancashire and Wilts.

As will, however, be shown later on, the statement made in the second annual report, for the year I902, to the effect that "County Councils have not, as a rule, realised the importance of thorough organisation in agricultural matters," remained, generally speaking, still applicable, notwithstanding various gratifying exceptions thereto.

\section{Colleges.}

From various colleges came much support for the movement, more especially in regard to educational matters.

At the University College, Aberystwith, some courses of lectures on "Agricultural Co-operation" were begun in I902 by Professor D. D. Williams, and in the following year Mr. Augustus Brigstocke, honorary representative for South Wales, and also a member of the Committee, presented to the governors of the college two scholarships of the value of $£$ ro each to enable diploma students to pursue these courses of lectures. 
The Agricultural Department of the University College of North Wales, Bangor, organised a series of "extension lectures" on "Agricultural Co-operation," the outcome of which was the formation of two new societies.

The Council of the University College, Reading, took part in the holding, in that town, on March 21st, I903, of a conference attended by Mr. Hanbury, Sir Horace Plunkett, Mr. Yerburgh, and others, at which a resolution affirming the desirability, in the interests of agriculture, of encouraging "the study and adoption throughout Great Britain of those principles of agricultural co-operation which have been for many years so successfully established in foreign courntries, and more recently in Ireland and several parts of England and Wales."

The present Director for Agriculture of the Reading College, Mr. R. Hart-Synnot, is most sympathetic and recently issued a circular letter to the principal newspapers in the counties of Hants, Dorset, Wilts, Berks and Oxon in support of agricultural co-operation.

Co-OPERATIVE UNION.

To the Co-operative Union and its late secretary, Mr. J. C. Gray, the Committee expressed themselves, as early as I902, " much indebted and very grateful for the advice and guidance given in matters of great importance" to the movement. These acknowledgments were renewed in I903. At the Igo4 Congress of the Co-operative Union the following resolution was passed :-

That this conference notes with satisfaction the growth of co-operation amongst agriculturists, as evidenced by the numerous co-operative societies established during recent years for the purpose of supplying farmers and others with the machinery, implements, manures, seeds, etc., required in their business, and also for distributing their produce on a co-operative system. Believing it desirable that a closer connection should be maintained between all branches of the co-operative movement in this country, the Congress pledges itself to assist in the development of co-operation in this direction by encouraging the Agricultural Organisation Society in its work, and by using its influence towards the establishment of mutual trading relations 
between the Co-operative Wholesale Societies and the Agricultural Societies.

The present General Secretary, Mr. Whitehead, continues the policy of his predecessor, Mr. Gray.

\section{FARMERs' Associations.}

Another feature of the good progress made was the number of societies formed as offshoots of existing farmers' associations, - a fact which fully confirms what has already been said as to the supplying of needs not met by the earlier agricultural organisations, however valuable the services they rendered in other directions. Of the 46 societies formed between January Ist, I905, and June 3oth, I906, seven originated with existing farmers' associations, and eleven more of these bodies were, on the latter date, considering proposals for the formation of co-operative societies. At a meeting of the Yorkshire Union of Agricultural Clubs and Chambers of Agriculture on June I9th, I906, it was resolved that clubs affiliated to the Union should be urged to form co-operative agricultural societies and a committee was appointed to carry this resolution into effect.

\section{The Press.}

To the Press of the country the A. O. S. is indebted for an almost general support, the exceptions being very few, and including various trade papers which thought that the interests of their own particular class of readers might be prejudiced by the movement. The articles published from time to time in London and provincial papers had a powerful effect in making the movement better known, and securing for it a still greater measure of public sympathy and encouragement.

The publication, in I904, through Mr. John Murray, of "The Organisation of Agriculture," a book which represented a substantial expansion of a series of four articles published in The Times at Easter in that year, giving details concerning the development of agricultural organisation in 
other countries and the position at home, was also considered to have served a useful purpose.

\section{Small Holdings Grant.}

Notwithstanding all this wide-spread approval of its objects and work, the Society continued down to Igog to be entirely dependent on voluntary contributions for the means by which that work could be carried on, and its powers of usefulness were severely restricted by the inadequacy of its finances. At the end of Igo8 the A. O. S. was the central body of $28 \mathrm{I}$ affiliated societies, viz., societies for the supply of requirements or sale of produce, I2I ; small holdings and allotments societies, III ; dairy societies, I3; agricultural credit societies, 20 ; farming societies, 3 ; auction markets, 3 ; industrial societies, 2 ; fruit-grading societies, 2 ; together with one motor service society, one milling society, the Agricultural Co-operative Federation, the Central Cooperative Bank, the Agricultural and General Co-operative Insurance Society, and the Scottish Agricultural Organisation Society. These affiliated societies had then a membership of about I5,000, and their turnover for the year was estimated at $£ 770,000$, while the financial position, in I908, of the parent Society, which was pioneering the whole movement and seeking to establish it on national lines, stood thus :-

$$
\begin{aligned}
& \text { Receipts- } \\
& \begin{array}{lllll} 
& & \ldots & s . & d
\end{array}
\end{aligned}
$$

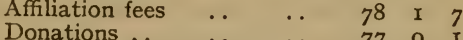

$$
\begin{aligned}
& \text { Guarantee fund called up.. } \quad 670 \quad 77 \quad \begin{array}{lll}
77 & 0 & 1
\end{array} \\
& \begin{array}{llllll}
\text { Other receipts } & \ldots & \ldots & 478 & 8 & \text { 10 }
\end{array} \\
& \begin{array}{llllll}
\begin{array}{c}
\text { Total receipts } \\
\text { Total expenditure }
\end{array} & \ldots & & 2,526 & \text { I5 } & 6 \\
& & 2,477 & \text { II } & 8 \\
\hline
\end{array}
\end{aligned}
$$

Some degree of relief, however, was to come to the A. O. S. in the form of a grant from the Board of Agriculture, made under the following circumstances. 
In April, 1905, the President of the Board of Agriculture appointed a Departmental Committee to enquire into the administration and working of the Small Holdings Act, 1892. The members of this Committee included the President of the A. O. S. (Mr. R. A. Yerburgh, M.P.), and among the witnesses examined were the secretary (Mr. J. Nugent Harris), and the then chief organiser (Mr. W. M. Tod) of the A. O. S., and representatives of some of the affiliated societies. In their report, dated December roth, I906, the Committee dealt with (among many other matters) the subject of co-operation as applied to small holdings, and said :-

The Committee are of opinion that practical steps should be taken by the Government to promote all forms of agricultural co-operation, and especially to encourage the formation of agricultural credit societies. The Committee have carefully considered the question whether it is desirable that the promotion of co-operation should be undertaken directly by the Government Department, or should be entrusted to a voluntary organisation which should receive a grant from the public funds. The Committee have dome to the conclusion that the propagandist work can be more effectively carried out by a voluntary organisation, more particularly if that organisation is of a representative character. They have considered the work which is being done by the Agricultural Organisation Society, and are of opinion that an annual grant should be made to the said society by the Board of Agriculture, under such limitations as the Board may think desirable.

Following on this report, Parliament passed the Small Holdings Act of 1907 , consolidated in the following year by the Act of r908. Small Holdings Commissioners were to be appointed; a special account, to be called "The Small Holdings' Account," was created ; and there was placed on County Councils the obligation to provide small holdings for bona fide applicants, compulsory powers for acquiring land being, to this end, given to the Councils and also to the Board of Agriculture in the event of the Councils not performing their statutory duty.

It was further enacted, by Section 49 (4) :-

The Board [i.e., the Board of Agriculture], with the consent of the Treasury, may, out of the Small Holdings Account, make 
grants, upon such terms as the Board may determine, to any society having as its object or one of its objects the promotion of co-operation in connection with the cultivation of small holdings or allotments.

As the result of this new legislation considerable demands began to be made upon the A. O. S. for assistance in the formation of co-operative small holdings and allotment societies, and the greater part of the time of the staff was engaged thereon, although the organisation of agricultural co-operative societies in other directions called for increased energy and was pushed forward with, if possible, still greater vigour.

It was evident that, under the Small Holdings and Allotments Act, the scope, purpose and future working of the A. O. S. would be very materially affected, and that, unless the Society were enabled to control larger funds than were then available, it could not possibly show itself equal to requirements. An application for a grant was made to the Board of Agriculture, which eventually agreed, with the consent of the Treasury, to a grant of $£ I, 200$ per annum for a period of three years from April Ist, I909, provided that the income of the Society from subscriptions and donations in each year was not less than $£ I, 200$. In the event of the income of the Society exceeding that sum the grant to be made by the Board was to be increased by a corresponding amount, with a maximum of $£ \mathrm{I}, 600$. Further conditions of the grant were that the Society should have a Committee of Management of twenty-four members, including six to be nominated by the Board of Agriculture and two by the National Poultry Organisation Society; and that the Society should appoint at least three organisers for the promotion of co-operation in connection with the cultivation of small-holdings or allotments, one of the three to be conversant with the organisation of co-operative societies for the production and sale of poultry and eggs.

The six members of the Committee of the A.O.S. nominated by the Board of Agriculture were:-Mr. E. J. Cheney and Mr. M. T. Baines (Small Holdings Commissioners), directly 
representing the Board; Mr. C. Roden Buxton and Mrs. Wilkins, nominated to represent the Central Small Holdings Society; the late Mr. J. C. Gray (general secretary of the Co-operative Union); and Mr. D. McInnes (secretary of the Midland Section of the Co-operative Union and a director of the Co-operative Wholesale Society), nominated to represent the Co-operative Union.

The National Poultry Organisation Society nominated the Marchioness of Salisbury and Col. R. Williams, M.P., as its representatives.

In further accordance with the conditions on which the grant was made three new organisers were appointed.

\section{D.-RECONSTITUTION.}

The concession of State aid through the grant which had been made by the Board of Agriculture was followed by a complete reconstitution of the Society as the result of a subsequent grant under the Development and Road Improvement Funds Act, I909, and the amending Act of IgIo.

Designed to "Promote the Economic Development of the United Kingdom and the Improvement of Roads therein," this new legislation led to the appointment, in May, Igro, of a body known as the Development Commissioners, by whom the objects of the Act were to be carried into effect. This was to be done through the administration of a "Development Fund," created by the setting apart annually of $£ 500,000$ from the Consolidated Fund for a period of five years, supplemented by such moneys as might from time to time be provided by Parliament for the purposes of the Act.

Under section I (I) it was provided that "The Treasury may, upon the recommendation of the Development Commissioners appointed under this Act, make advances to a Government department, or through a Government department to a public authority, college, school or institution, or an association of persons or company not trading for profit, either by way of grant or by way of loan, or partly in one way and partly in the other, and upon such terms and 
conditions as they may think fit " for a variety of purposes, the first-mentioned of which were :-

Aiding and developing agriculture and rural industries by promoting scientific research, instruction and experiments in the science, methods and practice of agriculture (including the provision of farm-institutes), the organisation of co-operation, instruction in marketing produce, and the extension of the provision of small holdings; and by the adoption of any other means which appear calculated to develop agriculture and rural industries.

The A. O. S. being " an association of persons not trading for profit," and having on hand (as will be explained later on) a scheme of Branch Devolution which would involve a complete reorganisation of its work, applied for an annual grant to meet the cost of that scheme.

An interim grant was made on July $25^{\text {th, }}$ I9II, subject to certain conditions which were duly carried out. The Society removed from Dacre House, Westminster, to more commodious premises at Queen Anne's Chambers, Westminster; it made the stipulated appointments, and it obtained extra clerical assistance in order to meet at once the emergency created by the substantial increase then proceeding in the work.

\section{BASIS OF RECONSTITUTION.}

The conditions recommended by the Development Commissioners to be attached to a permanent grant to the Society, so far as they referred to its reconstitution on representative and national lines, were indicated in a letter received from the secretary of the Development Commission, dated May 3oth, I9II, following on an interview between representatives of the Development Commission and the Society, at which the matter was discussed. Briefly stated, the conditions were as follows :-

I. The reconstitution and registration of the A. O. S. as a non-profit-earning Association under Section 20 of the Companies (Consolidation) Act of 1908.

2. The governing body to be partly elective and partly 
appointed, the appointed members being representatives of the Board of Agriculture, the County Councils Association, the Cooperative Union and other representative bodies.

3. On the District Committees, or Boards, to which would be entrusted the local administration of the Society's business, County Councils within the district should be strongly represented.

The letter further stated that the Commissioners were prepared to recommend the Treasury to make annually to the Board of Agriculture such grants as they may be satisfied are necessary for the energetic promotion of co-operation among agriculturists in England and Wales, and that these grants should be paid by the Board to the Society thus reconstituted.

The necessary resolutions for the voluntary winding up of the old Society, under the conditions of the Development Fund grant, were passed at meetings held in April and May, I9I2, and a new Society, with the same title, was registered under section 20 of the Companies (Consolidation) Act, 1908. The first Governors have been appointed jointly by the Board of Agriculture and the Development Commissioners, and are to remain in office until the first annual general meeting, to be held after April Ist, I9I4. Their present number is not fixed. Those now holding office are as follows :-

Mr. R. A. Yerburgh, M.P., President.

The Earl of Shaftesbury, K.P., K.C.V.O., Chairman of the Governors.

Mr. F. D. Acland, M.P.

Mr. Charles Bathurst, M.P.

Mr. S. Bostock.

Mr. W. Fitzherbert-Brock- Mr. Clement Smith. holes, D.L.

Mr. Philip Burtt.

Mr. E. J. Cheney.

Lord Strachie.

Mr. H. C. Fairfax-Cholmeley.

Mr. J. S. Corbett.

Mr. Rupert Ellis.

Mr. Duncan McInnes.

Mr. George L. Pain.

Mr. Abel H. Smith.

The Hon. Edward Strutt.

Mr. H. Jones-Davies.

Mr. Cyprian-Knollys.

Mr. A. Whitehead.

Mrs. Roland Wilkins.

Colonel Robert Williams, M.P.

Sir James Wilson, K.C.S.I.

Subsequently to the holding of the first annual general 
meeting of the Society, after April Ist, I9I4, the Board is to consist of 36 Governors, chosen as follows :-

Elective (including the President) . $\quad \ldots \quad$ I8

Appointed by the Board of Agriculture .. I2

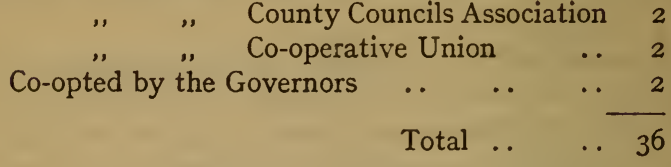

Power is taken either to increase or to reduce the number of Governors, provided that the same proportion as in the above list is maintained between the elective Governors (that is to say those who have been elected by the affiliated societies) and those appointed by the Board of Agriculture, though the total number is at no time to exceed 60 .

It will be seen that, in the first instance, a guarantee of proper expenditure of grants from the Development Fund is assured by the appointment of the first Board of Governors by the two bodies by or through whom the grants are made, while the fact that a number of the Governors so appointed have been chosen from the Executive Committee of the old Society will no less assure a continuity of experience and policy.

By the end of this first period the Society, as re-constituted, will have settled its policy, and have brought about, through its organising efforts, the formation of a much larger number of affiliated societies, and these will naturally expect to have a share in the work of administration. Hence the introduction of the elective element.

The reconstitution of the Agricultural Organisation Society on this greatly expanded scale of usefulness will have the effect of placing on a permanently established basis a movement previously dependent to so large an extent on voluntary support, though aiming at the accomplishment of a really national work. 


\section{Development Commissioners' Policy.}

In the second report of the Development Commissioners, being the report for the year ended March 3Ist, IgI2, it is stated :-

The arrangements for assisting the organisation of co-operation in Great Britain have been settled in outline. The principle adopted by the Commissioners has been in substance to utilise the existing voluntary societies which have done the work in the past, and entrust its extension to those bodies, reconstituted and strengthened by the admission of representative elements from outside. Two reasons have weighed with the Commissioners in adopting this policy. In the first place, they think that cooperation is particularly the kind of movement to which it is essential to retain the enthusiasm of voluntary workers. They fear that the grant of Government assistance, and the consequent measure of Government control, may to some extent weaken the spontaneous character of the movement; but they feel that it has a better chance of surviving under the arrangements now made, than if the necessary assistance which the Commissioners were glad to supply had been given to official bodies. Secondly, the geographical and other limitations of the available public authorities, at least in England and Wales, render them inconvenient and probably expensive agents for this particular purpose. The natural co-operative divisions of the country do not follow county boundaries, nor is the area which one organiser and his assistants can cover confined to one county.

Information is given as to the course taken by the Commissioners (on the lines already stated) in regard to the organisation of co-operation among agriculturists in England and Wales during the year covered by their report, and they say concerning the reconstitution of the Agricultural Organisation Society, in accordance with the terms of their grant :-

Owing to legal and other difficulties, the reconstitution of the Society probably cannot be effected before the end of the present summer. Meanwhile the Commissioners propose to recommend such grants as may be necessary to enable the Society to carry on its work pending reorganisation; when that event takes place they hope that the new Governing Body of the Society will be able to submit a scheme of extension which will command their approval and the Treasury's.

The action of the Commissioners in regard to the Agri-

A.O. 
cultural Organisation Societies of Scotland and Ireland is also recorded.

In June, IgIr, the Commissioners considered an application from the Scottish Agricultural Organisation Society (the story of which will be told in the section that follows) for an annual grant of $£ I, 500$. It was decided to recommend an advance for the current year equal to the amount spent by the Society from its own funds, but not in any case exceeding $£ I, 000$, and with the proviso that the Committee of the Society should be increased by the addition of members nominated by the chairmen of the County Councils and the Scotch Agricultural Colleges ; that the Society's operations should be in harmony with the scheme of work of the colleges; that the Society should appoint an additional organiser and have its accounts audited by an approved professional auditor; and that it should give particular attention in organising agricultural co-operation to the needs of small holders in that direction.

The question of assisting the organisation of agricultural co-operation in Ireland was found by the Commissioners to have been rendered more difficult by complications with party politics. An application from the Irish Agricultural Organisation Society for assistance was opposed both by the Department of Agriculture and Technical Instruction for Ireland and by the Irish Council of Agriculture, the latter body passing a resolution to the effect that any money available for agricultural co-operation in Ireland should be granted to and administered by the Department. A draft scheme, which contemplated a grant of $£ 9,000$ and the organisation of co-operative associations for the growing of fruit, early potatoes and flax, bee-keeping and lime burning, was prepared by the Department, but the Commissioners " were not satisfied that it amounted to a scheme for the organisation of agricultural co-operation in the sense which they felt bound to attach to those words," and " they could not, therefore, accept it as the Irish counterpart of the measures taken for that purpose in England and Wales and Scotland." At their meeting in March, I9I2, the Commis 
sioners heard evidence in support of the Irish Agricultural Organisation Society's application, and subsequently, the report adds, " they have recommended a grant of $£ 2,000$ to the Society, with prospective further grants, on conditions designed to secure that the Society's work is confined to purely agricultural co-operation, and that it is carried on without the possibility of any suspicion of political partisanship."

In explaining the "Finance of the Development Fund" the Commissioners say concerning agricultural co-operation :-

This expenditure under this head takes the form of grants to the three existing agricultural societies. $£ 50,000$ might be sufficient, but it is possible that this sum may be exceeded as co-operation is a subject to which the Commissioners attach great importance.

Finally, in their " Conclusion" the Commissioners say :-

The scheme for agricultural instruction and research, when in full operation, should at least go some way towards organising into a coherent system the more scientific side of agriculture in this country, as the schemes for promoting co-operation should help in organising its more commercial side.

\section{E.-DEVOLUTION.}

Reference has already been made, on page $\mathrm{I26}$, to the fact that when the Society approached the Development Commissioners, in I9I0, with a view to obtaining a substantial grant from the Development Fund, it had on hand " a scheme of Branch Devolution which would involve a complete reorganisation of its work."

Devolution was then by no means a new idea. There had been an initial development of this principle in 1904, or within three years of the Society being originally constituted. That particular development took place in regard to the work in Scotland.

Agricultural Organisation in Scotland.

Under the original plan of campaign, the A. O. S. was to take up the work of agricultural organisation throughout 
Great Britain in general, doing alike for England, Wales and Scotland what the Irish Agricultural Organisation Society was doing for Ireland. In this way some early attempts were made to foster propagandist efforts and promote the establishment of societies in Scotland. Owing, however, both to the labour and expense involved in carrying on such efforts from London and to the limited extent of the funds then controlled by the central body, the actual progress was so slight that down to the end of I904 only a single cooperative Agricultural Society-one, namely, at Tarff Valley, Kirkcudbrightshire--had been formed.

By this time, however, there had been brought about in Scotland a great awakening of interest in agricultural organisation. Captain John Sinclair, M.P. for Forfarshire, had visited Denmark and been so impressed by what he saw and heard that on his return he sought to induce some of his constituents to make up a party to go to Denmark in order to study the position there for themselves and apply, as far as practicable, to their own farming any lessons they might learn from Danish methods.

The reception given to his proposal can best be described in the words of an official report subsequently issued :-

The idea grew. What was a Forfarshire project developed into a project based upon a larger area of interest. TheSecretary for Scotland was good enough to agree that a member of the Congested Districts Board and Crofters' Commission should be invited to join the party. Members of Parliament of both political connexions contributed suggestion and aid in the composition of the Commission. Landlords of extensive acres in some cases became members; in others nominated their estate agents; in others, gave the names of tenants. The Highland and Agricultural Society and the Scottish Chamber of Agriculture appointed representatives. From the Agricultural Colleges, east and west, were drawn several members of the teaching staffs. Apart from these, the larger number of the Commission were well-known farmers hailing from all parts of Scotland, many of them with specialised interests, such as dairying, poultry-keeping and cattle-breeding.

Following on the attention which had already been so widely attracted in Scotland,"as in other parts of the United 
Kingdom, to the general subject, the report made on its return from Denmark by this Scottish Agricultural Commission of 1904 had a powerful effect on public opinion in Scotland.

In praising the Popular High School system in Denmark, the Commissioners thought they could not too strongly impress upon the sons of farmers, and all others contemplating a farmer's life, the necessity for taking a regular course of tuition at one of the Scottish Agricultural Colleges. On the subject of land tenure they thought a sound case was made out for creating a class of small holdings in the hands of cultivating owners. Concerning egg-collecting, they pointed out that the great and profitable egg export trade of Denmark rested upon numerous groups of peasant proprietors and cottagers who kept from Io to Ioo fowls each, and joined in co-operative societies for collecting, testing and marketing the eggs, and they thought that, although in Scotland the keeping of poultry for profit was less general, the practice would rapidly grow were similar organisations formed. Bacon-curing factories they considered to be clearly a phase of co-operation in which farmers might take the initiative to their common advantage, and they recommended the formation of district committees to consider the subject. By the Danish system of improvement of dairy cattle and keeping of milk records they had been greatly impressed, and they hoped there would be a more extensive adoption of the system in Scotland. In respect to State aid, they had found that in Denmark not only the various educational institutions, but all other organisations formed for the promotion of agriculture in its various branches were assisted and encouraged by grants in aid contributed from the National Exchequer, and they were of opinion that lasting benefit would accrue to British agriculture were the present small grants to colleges, dairy schools and experiment stations largely increased, and were the formation of associations for the promotion of rural industries in any practical and efficient manner also stimulated by assistance from the State. 
Finally, on the subject of "Co-operation," the Commissioners said :-

Although one great principle runs through all co-operative societies, the operations of that principle vary with the particular objects. There is much information to be gathered from Denmark, as well as from other European countries, which will be found profitable for guidance in the construction of a union, whether for the purchase of farmers' requisites or for collecting and marketing the products of farm, field and dairy. The tendency to greater co-operation is well set, even large farmers confessing its utility, and the tendency must strengthen with time. Of all origins of a co-operative society, the most natural and the best is the local origin-the unpretentious coming together of the few who are persuaded of the suitability of united action to the local conditions. But as an easily accessible source of information, and as an agency for helping the desires of beginners to take shape, an Agricultural Organisation Society would, it appears to the Commission, have a useful place in Scotland.

On January I8th, I905, a meeting convened by the Scottish Chamber of Agriculture was held in Edinburgh to consider what action should be taken. The meeting was attended by, among others, Mr. Yerburgh, President, and Mr. Harris, Secretary of the A. O.S. Mr. Yerburgh delivered an address on agricultural co-operation, and an influential committee was appointed to decide upon the best means of promoting the movement in Scotland. The committee met in April and, in turn, referred the question to a small sub-committee. Invited to attend a meeting of this subcommittee, Mr. Harris did so, and presented a memorandum strongly urging that Scotland should have an independent propagandist society of her own.

As the result of all these deliberations it was decided to form a Scottish Agricultural Organisation Society. An appeal for a guarantee fund of $£ I, 000$ a year for three years met with a liberal response; the Scottish Agricultural Organisation Society was inaugurated at a meeting held in Edinburgh on October 25th, I905, and registered on November I6th; active propagandist work was begun early in I906; the services of the then chief organiser of the A. O.S. 
were placed at the disposal of the society during the month of March, and the new organisation became an established success.

For the A. O. S. this formation of a sister society in Scotland was of great advantage, not only in relieving it of responsibility in regard to that country, but also in building up there an organisation which, though separate and distinct so far as regards all Scottish affairs, was affiliated to, and has joined cordially with, the A. O.S. for all purposes of mutual interest and support.

\section{GROWTH OF THE MOVEMENT.}

Thus far, therefore, devolution had been adopted with excellent results ; but there came a time when it was found desirable to carry the principle still further.

So great had been the growth of the movement by Igro that the Society even though it had been relieved of responsibility in regard to Scotland, was beginning to find the work in England and Wales beyond the powers of direction and control of a headquarters' staff in London. Even if a sufficiently large number of organisers could have been kept there to deal with an unwieldy mass of details, the expenditure of much time and money would have been involved in constantly sending those organisers to all parts of the country, while even then they would not have been able to keep in such close touch with new developments as could be maintained by organisers resident in the district.

This position will be more clearly understood from the following table, showing progressive growth, with number of societies, membership and annual trade turnover, since I90I :-

\begin{tabular}{|c|c|c|c|c|}
\hline AAR. & & Societies. & MEMbers. & TRADE. \\
\hline 190 & . & & 517 & \\
\hline & .. & $4 \mathrm{I}$ & I,094 & 16,274 \\
\hline & .. & 72 & 3,245 & $\begin{array}{r}38,909 \\
\end{array}$ \\
\hline & .. & 98 & 4,926 & I 36,677 \\
\hline & .. & .. $\quad \mathrm{I} 23$ & 7,439 & 221,524 \\
\hline 190 & .. & $\begin{array}{ll}. . & I_{37}\end{array}$ & 8,700 & 375, \\
\hline
\end{tabular}




\begin{tabular}{|c|c|c|c|c|}
\hline YEAR. & & Societies. & MEMBERS. & TraDE. \\
\hline & .. & 163 & 10,500 & 610,000 \\
\hline 1908 & .. & $28 \mathrm{I}$ & $r_{5}, 000$ & 749,000 \\
\hline 1909 & .. & .. 321 & 19,500 & 860,000 \\
\hline I9Io & .. & .. 396 & 24,000 & $1,100,000$ \\
\hline
\end{tabular}

\section{Branch Devolution.}

So, at the end of I9ro, this substantial expansion of the Society's activities led to a beginning being made with a fresh devolution policy.

The fundamental principle of the scheme then drawn up was the division of England and Wales into suitable areas, each of which would eventually have a Branch or Advisory Committee (or, as it was called in the first instance, a "Section") designed to link up the local societies and various local interests, and to deal, through its own administration, with all matters of detail in the general organising work within its own area, affording, to this extent, a material relief to the headquarters' staff, though still looking to the central organisation for control, guidance or direction in regard to questions of principle or matters on which expert advice might be desired. Each Branch was to be centrally situated, and was to have its own committee, its own offices, its own secretary, and its own staff of organisers, these officials being members of the headquarters' staff though working under the supervision of the Branch Committee.

While retaining the independence secured to them under their rules, and having their representation on the Branch Committee, the affiliated societies within each area were to be encouraged to look to the Branch office for such advice or assistance as they might need, as there would be obvious advantages in obtaining this advice and assistance in the aforesaid matters of detail from competent officials on the spot, and familiar with local conditions, in preference to having always to apply direct to London.

Apart from these practical benefits alike to the headquarters' staff and to members of the affiliated societies, the scheme would, it was expected, have a powerful effect in 
stimulating local interest and the spread of the movement. A closer intimacy with the farmers would be established; there would be increased facilities for arranging, holding and attending meetings and following up their results; and it would be possible, not only to watch closer over the welfare of societies already formed, but also to ascertain the exact conditions prevailing in every part of the country, which information would enable the A. O.S. to formulate and carry into effect a propagandist policy on scientific lines, and suited to the needs of each particular district. Then, also, it was thought that a Branch organisation would be able to adjust any difference that might arise between the various societies in its group in regard to overlapping. When societies are engaged in trade and their business is extending there is the risk that they may seek to push that business still further by invading what another society may regard as its own particular territory ; or, alternatively, new societies may be started in areas which existing societies might consider are sufficiently covered by their own activities. Matters of this kind could all be taken in hand by the local branch, with a consequent avoidance of friction and to the advantage of the operations in general.

Finally it was hoped that a further effect of this Branch Devolution scheme would be the securing of a larger amount of voluntary support.

\section{Constitution of BRANCHES.}

The precise details to be followed in the formation of the Branch Committees were to depend on circumstances ; but, generally speaking, it was proposed that they should include representatives of the County Councils, the Agricultural Colleges, local sections of the Co-operative Union, the railway companies, the A. O. S., and the affiliated societies in the counties included in the Committee's area.

Three Branches have been formed, namely a North Eastern Counties Branch, with Mr. Philip Burtt, Assistant General Manager of the North Eastern Railway Company, as chairman, to deal with the whole of Yorkshire, Durham 
and Northumberland, which three counties constitute in themselves a recognised area for agricultural produce; a North Wales Branch, with Lord Boston as chairman, for the counties of Anglesey, Carnarvon, Denbigh, Flint, Merioneth and Montgomery; and a Southern Branch, with the Earl of Shaftesbury as chairman, for Dorsetshire, Wiltshire, Hampshire and the Isle of Wight. The total number of Branches projected, to cover the whole of England and Wales, is fourteen or fifteen; though this number might be increased, should the continued growth of the movement render still further decentralisation desirable.

\section{Present Position of the A. O. S.}

The following statistics of co-operative societies affiliated to the Agricultural Organisation in September, I9I2, show the position of the A. O.S. at the time when it is passing under the control of the new Board of Governors :-

Societies for the Supply of Requirements of Sale of Produce .. I64 Dairy, Bottled Milk, and Cheese-making Societies $\quad . . \quad \ldots 23$

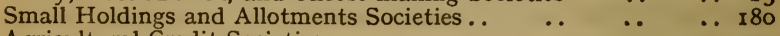
$\begin{array}{lllllll}\text { Agricultural Credit Societies } & \ldots & \ldots & \ldots & \ldots & \ldots & 45\end{array}$ $\begin{array}{lllllll}\text { Eggs and Poultry Societies. } & \ldots & \ldots & \ldots & \ldots & \ldots & 45\end{array}$ Miscellaneous Societies $\quad \begin{array}{lllllll} & \ldots & \ldots & \ldots & \ldots & \ldots & 24 \\ \end{array}$

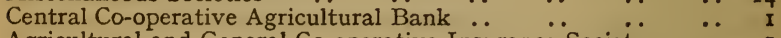
Agricultural and General Co-operative Insurance Society $\quad \ldots \quad$ I $\begin{array}{lllllllll}\text { Scottish A. O. S. } & \text {. } & \ldots & \ldots & \ldots & \text {. } & \text {. } & \ldots & \text { I }\end{array}$

The increases in (I) total membership of the affiliated societies and (2) the estimated aggregate money value of the transactions of the various societies in IgII over I9Io, may be shown thus :-

\begin{tabular}{|c|c|c|c|c|}
\hline & & I9IX. & г9хо. & Increase. \\
\hline $\begin{array}{l}\text { Membership } \\
\text { Turnover }\end{array}$ & : $\quad$ : & $\begin{array}{r}3 \mathrm{I}, 020 \\
£ \mathrm{I}, 33 \mathrm{I}, 083\end{array}$ & $\begin{array}{r}24,000 \\
£^{x, 0533,322}\end{array}$ & $\begin{array}{r}7,020 \\
£ 277,76 \mathrm{r}\end{array}$ \\
\hline
\end{tabular}




\section{EVOLUTION OF THE A.O.S.}

Among the larger trading societies the Eastern Counties Farmers' Association still takes the lead with a turnover of $£ 258,378$. The business done by some of the other large societies in I9II as compared with IgIo is shown by the following figures :-

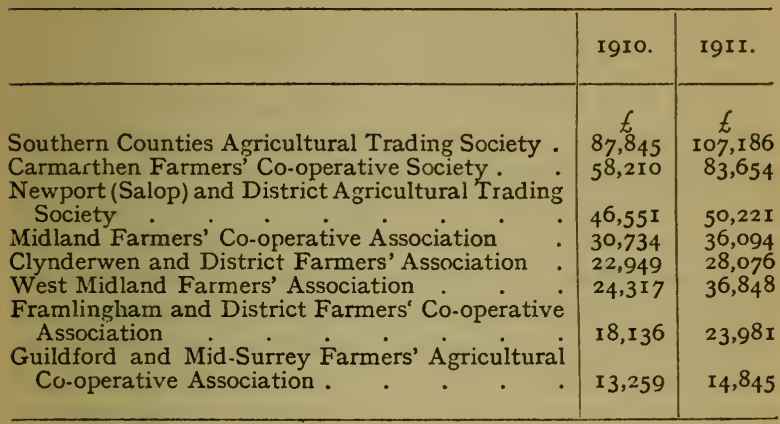




\section{CHAPTER VI.}

\section{TRANSPORT QUESTIONS.}

It will have been seen, from what has already been narrated on pp. 93-4, that the real beginning in England of the agricultural co-operation movement, as known to us to-day, was the invitation extended in I895 to Lord Winchilsea and other representatives of the agricultural interests to meet Lord Cland Hamilton, the chairman of the Great Eastern Railway Company, and various officers of that company, and confer with them on the general relations of the railways and agriculture. Prior to this conference, it would seem, Lord Winchilsea's efforts were mainly directed to the idea of securing Parliamentary action ; and it may be assumed that it was Lord Claud Hamilton's strong argument in favour of co-operation among the agriculturists themselves, in order to supplement thereby what the railways could or would do in their interests, that led to the movement taking a more practical direction, and one that, notwithstanding initial disappointments, was eventually to result in the widespread acceptance to-day of the co-operative principle.

\section{RaIlWay Policy.}

The action taken by the Great Eastern was followed by a general movement on the part of the leading railway companies in the direction of affording greater facilities to the agriculturists of the country for the transport of their produce.

It led, in the first instance, to the President of the Board of Trade, Mr. Ritchie, inviting the chairmen of railway companies having their termini in London to confer with him, on January 3oth, 1896 , concerning the question of facilities for the distribution of agricultural produce. The 
conference was duly held, and subsequently Lord Stalbridge, chairman of the London and North Western Railway Company, wrote on behalf of the Railway Companies' Association to Mr. Ritchie, explaining the railway position, stating what the companies were doing or were prepared to do, denying the existence of the alleged preferential railway rates for foreign produce (" equal rates under like conditions and circumstances are required by law and are in general operation ") and saying, also :-

As to reductions for large consignments, these are now given by all companies, and are provided for in many cases by the General Railway Classification of Goods Tariff. To obtain advantage of the lower scale under these regulations it is not necessary that all the goods in the larger consignments should be of the same description so long as they are in the same class.

Where the general railway regulations do not apply, lower rates for large consignments are frequently conceded by the companies, who desire to make known their willingness to receive and favourably consider such applications.

Combination amongst agriculturalists to increase the weight of consignments is a matter over which railway companies have little control, but they will gladly aid and co-operate in any effective movements in this direction.

On February r4th, 1896, the chairman, Sir George Russell, several of the directors, and the leading officers of the South Eastern Railway Company met, at the Cannon Street Hotel, representatives of the leading agricultural societies and farmers' clubs in the district served by their line who had been invited to come to London and inform the company, in friendly conference, what they would like the railway to do for them. The chairman announced that the company would be prepared to meet the requirements of the agriculturists "frankly, fairly and generously," and he invited suggestions. These were freely made, and resolved themselves mainly into requests for reduced rates, the delegates having previously agreed to ask the company for a reduction, by 25 per cent., of the rates for agricultural produce in general. At the close of the conference the delegates were invited by the chairman to form a committee of twelve to consult further with the company, and, as the final outcome 
of the deliberations thus entered upon, the members of the committee were informed, at a further meeting held on March 3oth, that the company had resolved to make a number of material reductions in their rates for agricultural commodities, besides putting on a special fruit train to run from Maidstone to London and connect with trains to the north. Mr. Cosmo Bonsor, then deputy-chairman, remarked in regard to these concessions that " a big instalment had been made in the right direction, and what had been done might be regarded as an earnest of what might be done in the future, the company being thoroughly disposed, in the interests alike of themselves and of the country, to encourage by every practicable means the prosperity of the district they served."

On April 2Ist, I896, the Great Western Railway Company had a conference at Paddington with leading landowners and agriculturists in the western and midland counties in order to ascertain their views and requirements, among those present being the Earl of Jersey, Sir W. Cameron Gull, M.P., Sir R. H. Paget, Sir A. F. Acland Hood, M.P., and Mr. Rew, secretary of the Central Chamber of Agriculture. Viscount Emlyn, chairman of the Great Western, who presided, said the question of railway rates had been brought to the front by the large amount of foreign competition, and a good deal had been said about advantages given to the foreigner. The Great Western had no desire to give any advantage to the foreigner ; but it must be remembered that the foreigner seemed to have gained his footing by sending his supplies in such a form that they could be handled with the smallest possible amount of trouble and cost to the railways. This was found, for example, in the carriage of meat. From Birkenhead to London train loads of meat, representing a minimum of 30 tons, were sent at a $25 \mathrm{~s}$. rate, and the farmers living between Birkenhead and London had wanted to know why they could not have the same rate. To this the Company had replied that if only the farmers would send consignments, not in 30-ton, but in 3-ton, lots, the company would quote them a lower rate. 
The consideration thus arose whether the farmers could not do something more to aggregate their supplies, and so secure these advantages. There were the further questions of markets and middlemen. A railway company could not take on its own account a course that might interfere with these interests, and thereby prejudice its own; but if any outside persons or agency would only take action with regard to these matters, the Great Western Company, with its large staff of servants, would be able to afford very valuable assistance; and he could assure them that the directors of the company would willingly discuss at any time any proposals put forward for dealing with these problems. Lord Jersey, who was among those taking part in the discussion, remarked that " a railway company might offer the greatest advantages, but these would not be of much use unless the producer did something to help himself."

The company followed up this gathering by sending officers into the principal agricultural districts served by the Great Western system in order both to enquire closely into the particular directions in which the agriculturists thought that further co-operation would be of value and to bring prominently to their notice the fact that, by adopting combination instead of acting independently, they might frequently obtain the advantage of rates for grouped consignments lower than those they were actually paying.

The London and North Western Railway Company did not hold a formal conference in London, as the companies already mentioned had done, but it sent, in this same year (1896), representatives to interview personally something like $\mathrm{I}, 000$ farmers having farms contiguous to their railway and to explain to them how, by combining and sending their commodities in bulk, they could already obtain the lower rates they desired. Commenting on this fact at a meeting of the Newport (Salop) and District Agricultural Trading Society on February 9 th, I905-presided over by the Duke of Sutherland, and attended, also, by the Secretary of the A. O. S.-Mr. Frank Ree, then the chief goods manager and now general manager of the London and North 
Western, added :- “ In spite of the efforts thus made, barely half-a-dozen farmers showed a willingness even to consider the matter, and the renewal of these efforts in Igo3 led to no better results than before." As further indicative of the policy of the London and North Western, mention might also be made of the fact that on the publication of "The Organisation of Agriculture," in May, I904, the chief goods manager sent a copy to each of the company's district officers in agricultural districts; and in January, 1905, a number of copies were forwarded to them with a letter from Mr. Ree, which stated :-

I am sending you to-day. copies of Mr. Edwin A. Pratt's book, entitled "The Organisation of Agriculture." Please make use of the books to the best advantage, going so far as to hand a copy to any large farmer or other person concerned in agriculture whom it will be well to educate on the lines advanced by Mr. Pratt.

It will be seen from these examples-without reproducing others which might be given - that, whereas the attitude of the agriculturists on the South Eastern system, when invited to state their requirements, had been simply to ask for a general reduction of rates on agricultural produce, even to the extent of 25 per cent., without any action being taken by themselves, the attitude of the companies in general was to point $(\mathrm{I})$ to the need for co-operation on the part of the producers, and (2) to the possibility of their obtaining, through co-operation, lower rates on the basis of those already existing. These two points-together with the need for more being done to effect co-operation than the railway companies themselves could do-were brought out very clearly in a letter, dated March 25th, I903, addressed by Sir Joseph Wilkinson, then general manager of the Great Western Railway Company, to Mr. Hanbury, President of the Board of Trade, in reply to a communication sent to the company on the subject of the railways and agriculture. In this letter it was said :-

It is a matter of general knowledge that in the past the farmers have frequently had just reason for being a $s$ :picious body of 
men as regards trusting the sale of their produce beyond their own observation; and a practical and practicable method of overcoming this difficulty would be hailed with satisfaction. It seems to me that an important duty might be performed if the Department could organise groups of agriculturists in various districts who would be willing to join together in forwarding butter, cream, eggs, honey, fruit and vegetables, mushrooms, game, dead rabbits, dead poultry and such-like products to selected markets and manufacturing towns; the Department, or some subsidiary authority, undertaking the selection of the persons to whom the consignments were to be sent and guaranteeing fair treatment and due payment to the farmer.

It has always been my opinion that any wide and comprehensive movement to be of a useful and lastingly beneficial character to agriculturists ought to emanate from and be conducted by themselves. There have in the last few years been great, stimulating and educational influences at work, and these, combined with certain elements of prosperity that have appeared, are making the farmer more regardful of outside influences than was formerly the case. If he is assisted with a due share of guidance and protection, and (from my point of view) if he is encouraged to believe that the railways would be his best friends if he would co-operate with them and regard them as such, there are great hopes of better times, in any case for the smaller forms of agriculture.

Sir Joseph Wilkinson expressed the view that these sentiments were universally felt by those responsible for the working of railways, always having regard to the varying requirements of the different portions of the country; and he continued :-

I would add that my company will be glad to meet in friendly conference any agriculturist who may have practical suggestions to make upon any point of mutual interest, and we are prepared to respond to all invitations and to send experienced officers to attend and give information at any and every meeting of farmers which may be summoned or brought about in our districts in connection with the renewed interest that is happily being awakened in agricultural matters.

As will have been gathered from what has already been told in the section on "Earlier Efforts," the railway companies were attempting at this time an almost hopeless task in endeavouring to secure combination for transport and sale without that preliminary education of the producers in 
co-operative effort which an independent propagandist body like the Agricultural Organisation Society could alone supply. None the less does the sincerity of the efforts made deserve recognition.

\section{LOWER RATES: INCREASEd Facilities.}

The fact must be further recognised that the railway companies which were thus urging the importance of cooperation, and pointing to the advantages in transport to be secured thereby, did, also, concede lower rates in certain directions, and offer increased facilities to the producers in others, with a view to rendering to them such assistance as they then considered practicable.

To meet, for example, a desire which had been expressed for lower rates for fruit, vegetables, meat, poultry, rabbits, butter, eggs and other produce sent by fast merchandise train, new tables conceding such rates were prepared and issued, authority being given to the senders to lump together or aggregate the various kinds of produce under conditions that would allow of such loads being made up as would justify the running of through trucks direct to the towns to be served; yet one company at least, the Great Western, found that the response of the farmers approached on this subject was not always encouraging, many of them being distinctly averse to any departure from established practices.

The companies were more successful with the special trains which (in addition to ordinary services) they ran to meet the requirements of seasonal traffic, such as broccoli, new potatoes, fruit, etc. Arrangements were also made by various companies for the supply, in return for moderate charges, of hampers, baskets, and cloths for meat and poultry traffic.

It might here be mentioned that, long before Lord Winchilsea came on the scene at all as the self-sacrificing champion of farmers' interests, the London and North Western Company had made special efforts to expand the Aylesbury duck industry, not only supplying cloths and hampers, but 
sending a man to collect the produce, carrying it by rail. delivering it to the London salesmen, and even obtaining from them the amount due to the sender, and remitting it to that person. This arrangement was a most convenient one for the senders, who were mostly producers of the "small" type, and in I880, when the business was in an especially prosperous condition, the accounts thus collected by the railway company for the senders amounted to over $£ 3,000$. On the Post Office granting increased facilities to the public for the remittance of small sums, the company found it no longer necessary to act as financial intermediaries for the Aylesbury duck-raisers, who, however, can still obtain from the railway company the hampers in which to send their ducks to market.

Several companies followed the example set by the Great Eastern in establishing the system of consignment, direct from farmer to consumer, of produce packed in non-returnable wooden boxes, of various sizes, supplied at a low charge by the railway company. Thus under the arrangements adopted by the Great Western Railway Company, in I904, any farmer who wished to send consignments of produce, up to $24 \mathrm{lbs}$., from a station on the Great Western system to a householder in London, could obtain from the company, at prices ranging from twopence to fivepence halfpenny each, wooden boxes holding just such supply of poultry, eggs, butter, cream, fruit, etc., as might be desired; while the railway company would carry such a box a distance of fifty miles by passenger train, and deliver it, within a certain radius, at the house of the consignee, for an inclusive charge of sixpence.

Some of the companies-including the Great Eastern and the Great Western-also incurred considerable expense in compiling and publishing pamphlets giving the names and addresses of farmers and others on their respective systems who were prepared to supply urban householders with regular or occasional boxes of produce; but the actual results, from a traffic point of view, were disappointing, while the box system itself was adversely criticised by leaders of the 
agricultural organisation movement, who held that it tended to encourage individualism on the part of the farmer in place of that principle of co-operation in which the greatest hopes of effecting an improvement in his position were centred.

The policy adopted by the railway companies in regard to the milk traffic is dealt with in the section on "The Dairy Industry," and references to the egg and poultry demonstration car in South Wales in April, I9Io, will be found in that on "Eggs and Poultry."

\section{The A. O. S. AND the RaIlways.}

Much attention had naturally been paid throughout by the A. O. S. to these questions of cost of transport, which it regarded as often being no less important to the grower than the two other items that influence so materially his final balance sheet-namely, cost of production and market prices. Where there is but a comparatively small margin between these two, an undue cost of transport may, of course, convert an otherwise possible profit into a loss.

While, however, there may have been, at first, a certain degree of prejudice entertained towards the railway companies in respect to their transport of English farm, market garden, or dairy produce, further experience showed that, although the action of the railways in regard, more especially, to various matters of detail, might still afford scope for criticism, the great need of the situation was, not to abuse the companies for their unwillingness to carry produce at unremunerative rates, but to induce the agriculturists themselves to adapt their business to the transport conditions which would enable them to secure the lower rates already often available, provided these conditions were fulfilled.

The complaint as to preferential rates, which had formed a leading item in Lord Winchilsea's original programme, appeared less substantial to the Society when it was looked at from the points of view here suggested; but there came 
a time when it was thought producers still had a grievance against the railway companies, inasmuch as, even when the societies were able to give very large orders for fertilisers, the companies would not quote lower rates than those that applied to much smaller quantities.

To this it was replied by the companies that when they fixed their minima for specially low rates at ten, four, or even at only two tons, they did so with the idea of enabling the small as well as the large producer to take advantage of them, and with the full expectation that large consignments, to which the rates would equally apply, would still be sent. It was further declared that the British farmers who could consign in 2-ton or 4-ton lots were being granted special rates which on Continental railways might be conceded only in respect to 5 -ton or Io-ton lots, such concessions being made by the English companies to meet the agricultural and trading conditions of this country; but there was no idea on the part of the companies that, as soon as consignments of Io, 20 or 40 tons or more could be made up, fresh series of minimum rates should be fixed to apply to these greater quantities. One company, in fact, protested that its rates for 4 -ton lots of fertilisers or other agricultural commodities had been fixed at " a very low basis which left no room for further reductions for lots of more than 4 tons."

As for any occasional huge consignment of fertilisers or other commodities which required the running of a special train, traffic of this sort was affirmed to be less acceptable to a railway company than the consignment of a few additional truck loads at a time, over a series of days, inasmuch as the special train would involve a certain amount of dislocation of the regular service, whereas the extra truck loads day by day, added to the ordinary goods trains, would not interfere with the regular service at all, and would, also, cost less, in proportion, in the way of working expenses.

The policy of the A. O. S. in regard to these questions of rail transport thus resolved itself mainly into one of showing 
how, by means of combination for the sending of large, in place of a series of small, consignments, material savings might be effected on the basis of existing railway rates, apart from any question of appealing to the railway companies for further concessions.

\section{Savings ON RaIL TRAnsport.}

Many examples of the economies possible in these directions came under notice.

Reference has already been made, on pp. I43-4, to the meeting of the Newport (Salop) and District Agricultural Co-operative Trading Society on February 9th, I905, at which the present general manager of the London and North Western Railway was one of the speakers. In addition to the matters mentioned as having been touched by him on this occasion, Mr. Ree further stated, on the subject of railway rates for agricultural produce, that a table which had been prepared by his company, giving details as to the traffic in the Newport district and the actual rates paid per consignment by the farmers, showed that, under the conditions then existing, over 80 per cent. of the consignments were carried at the higher rates on the company's rate books, and only 20 per cent. at the lower. By means of combination, in order that consignments could be sent in large quantities coming within the range of these lower rates, the small farmers who were members of that society could save something like I9 per cent. on their payments for rail transport.

In the issue of Co-operation for October, IgIo, reference was made to the fact that the 90 members of an agricultural co-operative society had been found to be sending each his own particular lot of produce to one and the same market. Such individual consignments generally averaged about half a ton, the charge for which, at the rate of $9 s .2 d$. per ton, was $4 s .7 d$. There was, however, a special rate of 6s. $3 d$. per ton for consignments of not less than 4 tons, and it was shown that if eight growers each put his half-ton lot 
to make up this minimum the saving effected would work out thus :-

8 consignments in separate $\frac{1}{2}$-ton

Total Cost. Cost Per Sender. lots

$$
t \text { s. } d \text {. S. } d \text {. }
$$

8 consignments in one 4 -ton lot..

Saving

\begin{tabular}{lrllll} 
I & I6 & 8 & & 4 & 7 \\
I & 5 & 0 & & 3 & I $\frac{1}{2}$ \\
\hline II & 8 & & I & $5 \frac{1}{2}$
\end{tabular}

The average weekly payments per grower for rail transport came to $f \mathrm{I}$, and the average annual saving per grower made possible by the figures just given would have been $£ \mathrm{I}$. Multiplying this by 90 , the number of members in the society, it will be seen that the total saving per annum that might have been effected by them in railway rates, by means of combination, and without their asking for any further concessions, was no less than $£ r, 530$.

The following further example of possible savings in the same direction has been thus recorded by one of the organisers of the Agricultural Organisation Society :-

As the result of an arrangement between the Cambridgeshire County Council and the A. O. S., I paid a series of visits to that county in the spring of IgII. The first place I visited was Cottenham, where I found that the small holders were at a great disadvantage in matters of transport. They were consigningmostly vegetables-at a rate of I5s. per ton to London, for small quantities, and at one of $26 \mathrm{~s}$. $6 \mathrm{~d}$. per ton to Manchester. I pointed out to them that there were special rates of $7 s$. $I d$. per ton to London and I5s. $5 d$. per ton to Manchester, which would enable them to effect a material saving if only they adopted the principle of co-operation and grouped their consignments into the stipulated quantities. They acted on my suggestion, a whole season's produce has since been despatched from Cottenham at the lower rates, and the small holders have expressed the warmest thanks for having the matter brought to their notice.

Thus the Agricultural Organisation Society has often succeeded where the railway companies themselves had previously failed in bringing about the combination needed for taking advantage of lower rates already on the companies' books; and this result may be attributed mainly to (I) the distrust with which the naturally suspicious mind of the 
British agriculturist had regarded the earlier advances made by the railway companies-a distrust inspiring the idea that the companies were merely seeking some advantage for themselves; and (2) the absolute need for independent educational and propagandist efforts as a means of converting the producers from their old prejudices, of bringing home to them the practical advantages of combination, and, still more, of providing the machinery by which such combination can be carried into effect.

\section{MOTOR SERVICES.}

One interesting development in the application of combination to transport is represented by the motor wagon service established in 1904 by the North Eastern Railway Company as a means of communication between their railway system and the depôt-now a commodious building -of the Brandsby (Yorkshire) Agricultural Trading Association, Limited. The service has been of great advantage in many ways to growers in the district, but the inauguration of it would have been wholly impracticable had there been no local society to group consignments, to bulk orders for requirements, and otherwise to organise the traffic generally, supplementing efficiently, in these respects, the means which the railway company themselves were prepared to adopt in the joint interests of the agriculturists and of their own traffic.

A like service was also established by the Great Western Railway Company in the Teme Valley; but in this instance the results were not considered sufficiently encouraging to warrant the continuance of the arrangement. There would, in fact, seem to be a tendency on the part of agriculturists to assume that, when a railway company provides the motor wagon, they need only send by it when their own horses, vehicles and drivers are otherwise engaged, the consequence being that there is a risk of a regular service not paying expenses. Whatever the reason, it is a matter for regret that these motor services have not been established far more generally. 


\section{RaIlway Station Depôts.}

Another outcome of organised effort is to be found in the setting up at country railway stations of depôts to constitute the headquarters of the local agricultural co-operative society in the collection, storing or distribution of members' produce or necessaries consigned or received by rail.

In the first instance the railway companies themselves constructed these depôts, and charged the societies a rental sufficient to cover interest on capital expenditure. There arose, however, the risk that a want of success on the part of a local society might leave the depôt on the hands of the railway company. The societies, in turn, say that in certain instances the railway companies, in their desire to assist the movement, incurred greater expenditure in connection with the depôts than was really necessary. More recently the railway companies have been reluctant to provide the depôts at their own cost, though they have offered facilities to the local societies to build depôts for themselves by letting them have the necessary land in return for a nominal rental; and this, probably, will be found the better arrangement.

In one or two instances the difficulty has been solved by the railway company partitioning off part of an existing goods shed at a country station, and letting such portion to the local society. In still other places, where only a limited amount of accommodation has been required for such purposes as egg collecting and grading, the railway company have provided for the society-and again at a nominal rental -an old goods van which had been retired from active service on the line.

At Holsworthy (Devonshire) the London and South Western Railway Company constructed some years ago, on their station premises, a slaughter-house for the convenience of dealers purchasing fat cattle in the district, the cattle being taken to the station, killed in the slaughter-house, and consigned by train in such quantities to the London markets that at certain times of the year six or eight truck loads of meat are dispatched. The members of the local agricultural 
co-operative society, being under the impression that the slaughter-house could be used by the dealers only, requested the Society to approach the London and South Western Railway Company with a view to the provision of similar accommodation at Holsworthy station for its own members. A deputation accordingly waited on the chief goods manager of the railway company, who replied that the members of the society were entitled to use the slaughter-house equally with the traders on their making the payments fixed by a scale of moderate charges, and the officer in question added that if the society could make any suggestion as regarded additional accommodation on other parts of the line, and could show that the provision of it would not involve a loss, he would gladly support any such application that might be made to his company.

\section{Classification of Cucumbers.}

Then an important concession has recently been obtained from the railway companies in an altered classification of cucumbers which, though of special benefit to the Worthing and District Market Growers' Association, applies to the lines of all the companies connected with the English Clearing House system, and is thus of far greater value than a concession in the interests of Worthing only would be. The Worthing Association, it might be added, was originally formed mainly to enable the growers to secure the lower rates offered by the London Brighton and South Coast Railway on bulk consignments of grapes, tomatoes and cucumbers.

Fruit TRANSPORT.

In another direction the Swanwick (Hampshire) Fruit Growers' Association adds to its other useful functions by making known to the railway companies the needs of the district with reference to the fruit traffic and by seeking to bring about the general use of baskets of uniform size and holding standard weights of fruit. 
Railway Co-operation with the A. O. S.

Mention has already been made of the fact that Mr. Philip Burtt, Assistant General Manager of the North Eastern Railway Company, is chairman of the North Eastern Branch of the A. O. S. and a member of the new Board of Governors.

To show still further the practical assistance which the railways are giving to the movement, it might be added that Mr. G. T. Phizackerley, District Traffic Superintendent of the London and North Western Railway at Chester, has been appointed on the executive committee of the North Wales Branch of the A. O. S., and is showing great activity in promoting the movement in that part of the country. It is, in fact, understood that the London and North Western Railway Company are taking considerable interest in the work of the Agricultural Organisation Society, that the whole tendency of their policy is to encourage the formation of agricultural co-operative societies, and that they have, from time to time, given to their officers definite instructionsrecently renewed-to offer every encouragement to, and every facility for, the setting up and successful operation of such societies, this line of action to be taken throughout the company's system.

With direct representation of the railway companies, not alone on the Board of Governors of the A. O. S. but, also, on all the Branch committees which, it is suggested, should eventually be formed to cover the whole of England and Wales, the possibility of ensuring harmony and co-operation in the mutual relations of agriculturists and the railways, to the advantage of both, should be still further very materially increased.

\section{ROAD TRANSPORT.}

Cost of transport by rail is, in many instances, only one of two important items of expenditure in getting produce from farm or small holding to market, the other being cost of transport by road, either as between farm and railway station or as between farm and market, the latter provided that the commodities can be sent the entire distance by road. 
When the individual farmers or small holders are left to their own resources in getting their produce to the railway, it may happen that the cost, even although the station is only a few miles away, will work out at a higher rate per ton than the charges for consignment by rail to destination. For instance, the sums per package paid by a group of small holders at Cottenham, Cambridgeshire, for the transport of their individual consignments of potatoes and vegetables to Oakington station, on the Great Eastern Railway, situate only two miles away, were found to represent a road transport rate equal to about $24 \mathrm{~s}$. or $25 \mathrm{~s}$. per ton; whereas the same produce was being carried by rail from Oakington to London, a distance of 62 miles, at a rate, for small consignments, of I5s. per ton, which would have been reduced to one of $7 s$. $\mathrm{I} d$. per ton if the senders had made up consignments of 4 tons.

Should a district be situated at any distance from a railway station with which frequent communication is maintained, great advantage is to be derived from the setting up of a motor wagon service, in combination with a local co-operative society, for the collection and transport of the produce of farmers and small holders within a certain area, thus relieving them of any need for making individual arrangements ; and the advantage is greater still when the same service can be used for bringing from the railway, on the return journey, commodities necessary for use on the farm or holding.

\section{LIGHT RAILWAYS.}

Light railways constitute another phase of the transport problem, and one which, as an alternative either to motor wagons or to the much more expensive type of ordinary railways, is certain to attract increased attention in the near future.

Road motors, operated in conjunction with an agricultural co-operative society, may, indeed, to a certain extent be regarded as the precursors of light railways inasmuch as 
their tendency, under an efficient system of operation, is to expand the traffic to such an extent that a motor service may become no longer adequate in the course of a few years, and the need will then have been created for still further facilities which a light railway would be best adapted to supply.

These conditions are well brought out by the Light Railway Commissioners in their fifth annual report to the Board of Trade on their proceedings to December 3Ist, IgII, wherein they make the following references to motor traction, light railways and co-operation in agriculture :-

With regard to the great development in recent years of motor traction upon public roads, it is of interest to note that, in our experience, confirmed by the two cases of proposed light railways which we have most recently had under consideration, the establishment of a service of motors (in each case combined with the organised co-operation of the agricultural and other local industries) has tended to stimulate the desire, and to emphasise the need, for better railway facilities, rather than (as it is sometimes supposed would be the case) to supersede them, or to take their place. In these cases evidence was brought to show the considerable extent of saving to the road authorities in the annual cost of maintenance which would follow from a transference to a railway of the traffic otherwise carried on the public roads ; this point was also in accord with our previous experience as bearing on the economy of transport by railway.

In making these observations, we appreciate that in districts where it is not practicable to construct a railway, and where the traffic is not sufficient to support one, a motor service (especially when combined with some "co-operative" system) may be of much use, and in many cases would develop the traffic to a point at which railway facilities would become requisite and feasible for the further progress of the district.

One especially significant example of the tendencies in question is afforded by the aforesaid Yorkshire village of Brandsby, where the success of the motor service connecting with the North Eastern Railway system has led to an application being made to the Light Railway Commissioners for an order sanctioning the construction of a light railway. An enquiry into the matter was held by the Light Railway Commissioners at York on February 2oth, rgr2.

It was shown at this enquiry that the motor wagon service 
is now carrying about 2,000 tons of goods a year for the Agricultural Association established at Brandsby, the population of which place is 325. Not only has the service been of great practical advantage, but it has become wholly unequal to present requirements. In certain parts of the district which cannot take advantage of the service at all the cost of haulage to or from the railway is prohibitive. Farmers there are obliged to be content with making butter, though they would gain more-if only adequate facilities were available-by sending their milk to York, which is the natural market for the district. In some localities, through which the proposed light railway would pass, the only direct communication with York is by a carrier's cart, occupying three or four hours on the journey. Farmers at a distance of five or six miles from the railway are unable to obtain, at a sufficiently low cost for transport, the manures which would increase the production of their crops. Even at Brandsby itself the farmers may be deprived of the use of the motor wagon when, in wintry weather, the roads are impassable.

Hence the proposal for a light railway. Starting from Brandsby it would have a total length of nine miles, and connect with the North Eastern system at Haxby, four miles north of York. The district it would serve comprises 20,000 acres, and has a population of about 3,000. In this district there are eleven villages, the present average distance of which from a railway is five miles. The line is to be a full gauge one ; it will have three stations and two halts, and it will be operated with a single engine, (steam), and practically without signals. The estimated cost is $£ 34,000$, including $£ \mathrm{x}, 500$ for land and $£^{2}, 500$ for contingencies. It is proposed to raise $£ 36,000$ by ordinary shares and $£$ I2,000 by debentures.

In regard to prospective traffic, the Brandsby Agricultural Trading Association itself expects to provide at least 3,200 tons a year. A good milk traffic is anticipated; the greater use of manure should ensure more traffic in itself and further increase the output of produce available for 
transport; improved facilities for travel should develop the residential possibilities of the district, while a still further argument put before the Light Railway Commissioners in favour of the proposed line was that a light railway would save the local rates by lessening the wear and tear of the roads.

So conclusive was the case thus made out in favour of the scheme that the Commissioners had no hesitation in deciding in favour of granting an order authorising the construction of the line. This order they have since made and submitted to the Board of Trade for confirmation.

The position at Brandsby is deserving of this detailed reference because it is, in many ways, typical of the position of many agricultural districts throughout the country, and, also, because it foreshadows what may be expected to happen in other places where an improvement in existing transport facilities is begun with an organised motor wagon service under some mutually satisfactory arrangement between a railway company and an agricultural co-operative society, itself receiving the loyal support, in this particular matter, of members seeking, if only in their own interests, to make the scheme a success.

The main-line railway system of the country may be regarded as practically complete; but there is still great need for the building of more light railways which would link up undeveloped or inadequately developed districts where railways of the ordinary type would not pay, while the choice for such light railways of the standard gauge of main line railways would allow of a ready transfer of rolling stock from the one system to the other.

The whole subject is so intimately connected with the welfare of agriculture, with the possible success of colonies of small holders, and with the further development of our national resources, that it may well claim the special study and attention of the Agricultural Organisation Society.

\section{FROM FARM TO MARKET.}

With the improvements brought about in motor construction and in the roads of the country there is certain to be a 
considerable development in the transport of farm and market garden produce by road in place of transport by rail. The new conditions allow of a steady expansion of the suburban area within which such road transport is practicable, while the railway companies, with their heavy outlay on lines, stations and goods depôts, and the increase in their wages bills, taxation, and other items falling under the head of working expenses, are heavily handicapped in meeting the competition of a road transport that, among other advantages, has fewer expenses to cover and can convey produce direct from farm or local depôt to market.

On the other hand it has to be remembered that the possibilities of road transport are still limited by distance; that where agricultural produce is carried in large quantities the locomotive, counting as a single unit, may still be a more economical form of transport than an equivalent number of motor lorries, each counting as a separate unit; that in proportion as the increasing road traffic takes business from the railways, the latter may seek compensation by encouraging still further their long-distance traffic, with a corresponding effect on the markets, and leading to still greater risks of gluts thereon, unless precautions are taken along the lines of a scientific marketing of agricultural produce operated through the agricultural co-operative societies which the A. O. S. has sought to establish, and that, as the example of Brandsby shows, the setting up of an organised motor service may, for a variety of reasons, be only the precursor of demands for increased rail facilities. 


\section{CHAPTER VII.}

\section{SUMMARY AND CONCLUSIONS.}

THE facts here narrated will, it may be hoped, have sufficed to prove the following fundamental propositions:-

The need for agricultural organisation was originally brought about by a combination of causes, including (I) the greater application of science to production; (2) the consequent growth of commercial industries for the provision of fertilisers, concentrated feeding stuffs, machinery, etc., which, if the farmer is to produce his crops economically, he should be able to obtain, at the lowest price and of the best quality, without having to pay too much for intermediate profits; $(3)$ the greater influx of food supplies from abroad following on $(a)$ the development of virgin soils in new countries, $(b)$ the increased facilities for ocean transport, and $(c)$ the application of refrigeration to the carriage of perishable commodities; (4) the effect of the telegraph on commercial relations with distant lands ; and (5) the whole tendency of to-day for business matters of every kind, including therein the business of agriculture, to get more and more into the hands of powerful combinations against which the isolated producer, and more especially the isolated farmer, cannot hope to protect adequately his own particular interests.

The chief aim of the agricultural organisation now being resorted to by civilised countries large and small throughout the world is to meet these conditions by the formation of societies operating mainly on the co-operative principle for (I) purchase of agricultural requisites; (2) provision of greater credit facilities for the cultivator ; (3) the application to various forms of agricultural production of that "factory" principle which has done so much to expand 
urban industries; (4) the ensuring of an effective distribution of agricultural produce on the basis of scientific marketing; (5) utilisation of surplus supplies in times of overproduction, thus avoiding either waste or an undue fall in prices through gluts on the market ; (6) reduction of the cost of rail or road transport by means of combination; (7) improvement of live stock; (8) co-operative tenancy of land ; (9) insurance, and, in fact, for every purpose connected with agriculture in regard to which combined action may be of advantage.

The right of the agriculturist to resort to organisation on these lines cannot reasonably be disputed since, although his doing so may, to a certain extent, appear to prejudice the interests of middlemen now thriving on his past neglect of his own interests, it has to be remembered (I) that the farmer, as a manufacturer of agricultural produce (for such he may claim to be), is, under the recognised customs of the commercial world, entitled to have direct dealings with manufacturers of the raw materials, the implements, and the machinery of his industry without being compelled to purchase through agents, dealers or local shopkeepers in the same way as a suburban resident growing vegetables in his own garden for domestic consumption might be expected to do ; (2) that by the formation of agricultural co-operative societies, which group the requirements of their members, orders can be given on a scale well justifying direct dealings; (3) that if agriculture, still the greatest of our national industries, is really to flourish, there must, whatever other remedies are adopted, be a reduction in those intermediate commercial profits which, on the one hand, increase unduly the cost of production, and, on the other hand, make too great a difference between what the producer receives and what the consumer pays; and (4) that in close alliance with this question of the farmer's profits are many other matters including those of no less material concern than the wages and the housing of the agricultural labourer (who also stands to benefit if the business of agriculture can be made a more remunerative 
one), and the offering of greater inducements for settling more people on the land under the scheme for the extension of small holdings.

The wisdom of the principles and practice of agricultural organisation, as adopted and now being actively promoted by the central propagandist societies of England and Wales, of Scotland and of Ireland respectively, is no less beyond all reasonable doubt since we have abundant evidence of the fact that the movement in each country is proceeding along thoroughly practical lines, has already accomplished good results, and has laid solid foundations for still greater efforts in the future.

Thus the subject of Agricultural Organisation, in its many different phases, may be commended to the attention of the British Public as a National Question well deserving of their serious and most sympathetic attention, while they will see that, although Great Britain has hitherto been behind certain of the other countries in taking this all-important work in hand, the right lines have now been adopted, the difficulties of the pioneering stage have been surmounted, and a happy combination of voluntary effort and State aid, each supplementing the policy and the possibilities of the other, should ensure in the immediate future a greatly accelerated rate of progress, to the advantage alike of agriculture, of agriculturists and of the national well-being as a whole. 


\section{Agricultural and Transport Questions}

WORKS BY EDWIN A. PRATT

\section{Agriculture.}

The Organisation of Agriculture. 480 pp. Third Edition. 18. net. By post, 18. 4 d.

The Transition in Agriculture. $350 \mathrm{pp}$. Cheap Edition. 18. net. By post, 1s. $4 \mathrm{~d}$.

SMALL Holders : What they Must do to Succeed. $256 \mathrm{pp}$. 18. net. By post, 1s. 3d.

Agricultural Organisation: Its Rise, Principles and Practice Abroad and at Home. $270 \mathrm{pp}$. 3s. 6d, net. By post, 3s. 10d. [Includes a detailed account of "Work Done or Projected " by the Agricultural Organisation Society, not given in the Cheap Edition.]

Traders, Farmers aNd Agricultural Organisation: An Inquiry into an Alleged Conflict of Interest. $32 \mathrm{pp}$. $3 \mathrm{~d}$. net. By post, $4 \mathrm{~d}$.

\section{Transport.}

A History of Inland Transport and Communication in England. 542 pp. 6s. net. By post, 6s. 4d. [Deals with Roads, Coaches, Turnpikes, River Navigation, Canals, Railways, Tramways, Motor Buses, Cycles, Motor Vehicles, \&c.]

\section{Railways and the state.}

The Case Against Railway Nationalisation. 264 pp. 1s, net. By post, 18. 3d. [Published in "The Nation's Library."]

IRISH RAILWAYS AND THEIR NATIONALISATION. 44 pp. 6d. n't. By post, 7d. [A detailed criticism of the report of the Vice-Regal Commission.]

State RAILWaYs. $108 \mathrm{pp}$. 1s. net. By post, 1s. 2d. [Includes a translation of M. Marcel Peschaud's articles on "Les Chemins de Fer de l'Etat Belge."]

The State Railway Muddle in Australia. 168 pp. 2s, 6d. net. By post, 2 s. $9 \mathrm{~d}$.

\section{Rallways and Traders.}

RAILWAYs AND THEIR RATES. 362 pp. 1s. net. By post, 1s. 3d.

GeRMAN $v$. British RAILWAYs: With special reference to Owner's Risk and Traders' Claims. 64 pp. 1s. net. By post, 1s. 2 d.

GERMAN RAILWAYS AND TRADER8, 46 pp. 6d. net. By post, 7d. [A digest of the Board of Trade Railway Conference report on German Railways.]

\section{Railways in America.}

AMERICAN RAILWAYs. 310 pp. 2s. 6d. net. By post, 2s. 10d. reprint, with additions, of a series of articles contributed to The Times.]

\section{Canals.}

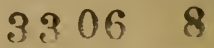

CANALS AND TRADERS. 124 pp. Nine maps and diagrams, 43 photographs. Cloth, 2s. 6d. net. By post, 2s. 10d. Paper covers, 18. net. By post, 1s. 3d. [The "Argument Pictorial," as applied to the Report of the Royal Commission on Canals and Waterways.]

Any of the above works will be forwarded by post, at the prices mentionod,

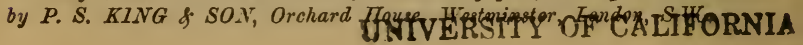


.

$-$ 


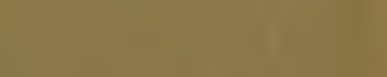




\section{UNIVERSITY OF CALIFORNIA LIBRARY}

\section{Los Angeles}

This book is DUE on the last date stamped below. 
183 A ricultural or 38a anisation

\section{4}

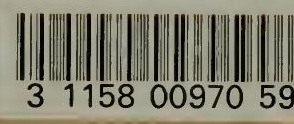

UC SOUTHERN REGIONAL LIBRARY FA

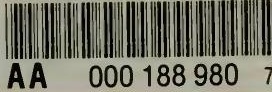

\section{$\mathrm{HD}$}

1483 P88a

1914 


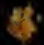

